\title{
THESIS
}

\section{CHARACTERIZATION OF SOLIDS IN PRODUCED WATER FROM WELLS FRACTURED WITH RECYCLED AND FRESH WATER}

\author{
Submitted by \\ Gen Li \\ Department of Civil and Environmental Engineering \\ In partial fulfillment of the requirements \\ For the Degree of Master of Science \\ Colorado State University \\ Fort Collins, Colorado
}

Summer 2015

Master's Committee:

Advisor: Kenneth H. Carlson

Pinar Omur-Ozbek

Thomas H. Bradley 
Copyright by Gen Li 2015

All Rights Reserved 


\section{ABSTRACT \\ CHARACTERIZATION OF SOLIDS IN PRODUCED WATER FROM WELLS \\ FRACTURED WITH RECYCLED AND FRESH WATER}

Water management is a central issue in oil and gas development. Hydraulic fracturing applied in unconventional tight oil and gas development requires large amounts of water, and the wastewater that results after production--containing high levels of organic and inorganic matter-usually is disposed of through deep well injection. A new approach reuses this produced water as part of subsequent fracturing fluid, an alternative that could significantly reduce both fresh water demand and the cost associated with deep well injection. However, produced water must be treated prior to reuse, to remove most of the suspended solids and multivalent ions that would otherwise cause scale or clogging problems. Understanding the amount and composition of solids in produced water is crucial in achieving optimized treatment and reuse.

This study targeted the characterization, both qualitatively and quantitatively, of the solids in produced water from oil and gas operations and the comparison of solids from wells fractured with fresh water and recycled water. Samples were collected from five wells at the Crow Creek and Chandler State pads in the Wattenberg field of Northern Colorado. Wells in the same pad were fractured either with fresh surface water only or with water blended with some portion of recycled produced water. Gravimetric analyses of dissolved and suspended solids were performed, and particle size distributions of suspended solids were measured. Suspended solids also were isolated and characterized with X-ray photoelectron spectroscopy (XPS).

Gravimetric analyses showed that total dissolved solids (TDS) averaged about 24000 $\mathrm{mg} / \mathrm{L}$ and $17000 \mathrm{mg} / \mathrm{L}$ for Crow Creek and Chandler State wells, respectively. Total suspended 
solids (TSS) concentrations were much lower, measuring 550 and $260 \mathrm{mg} / \mathrm{L}$ for the two pads. About 9 to 25 percent of TDS was volatile and 88 to 99 percent of TSS was highly volatile. Particle sizes were high during first few days of production and then stabilized at about $400 \mathrm{~nm}$ and $900 \mathrm{~nm}$ for wells on the Crow Creek and Chandler State pads, respectively. At the Crow Creek pad, particle sizes were smaller and mono-distributed in produced water samples collected during the first week of production from the well fractured with recycled water, suggesting that the recycled water was more compatible with shale formation and that wells fractured with recycled water tend to clean out faster. XPS tests for isolated suspended solids showed the presence of major elements such as oxygen, carbon, and silicon, along with minor elements such as calcium, magnesium, zirconium, iron, and others. Core-level scanning confirmed that the isolated suspended solids were mainly composed of carbonate based minerals and metal oxides; several iron compounds with different valences were also found in the produced water samples. 


\section{TABLE OF CONTENTS}

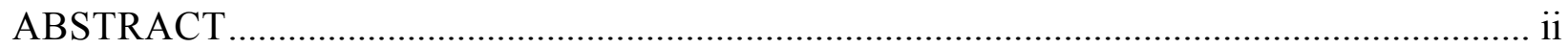

LIST OF TABLES ….................................................................................................

LIST OF FIGURES .................................................................................................. vii

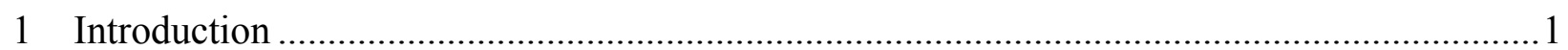

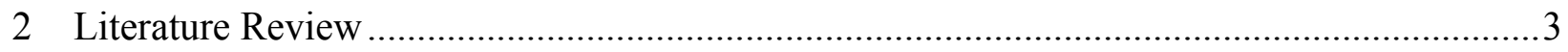

2.1 Unconventional Oil and Gas Development ................................................................

2.2 Hydraulic Fracturing and Horizontal Drilling .........................................................5

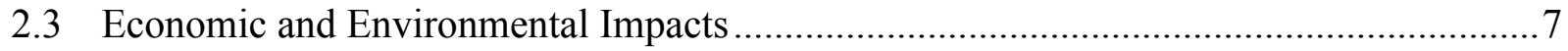

2.3.1 Economic Impact........................................................................................ 7

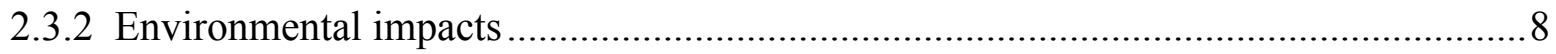

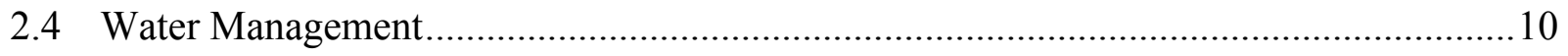

2.4.1 Water Demand ............................................................................................... 10

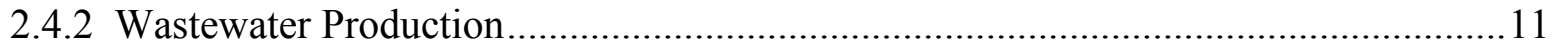

2.5 Characteristics of Produced Water .......................................................................... 13

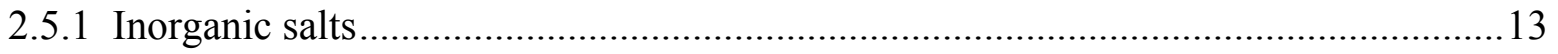

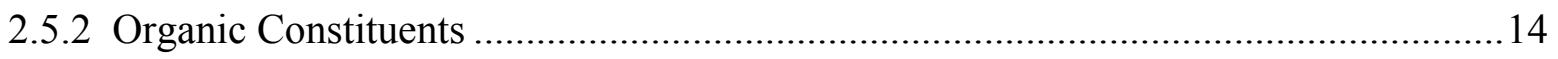

2.5.3 Naturally Occurring Radioactive Material (NORM).........................................15

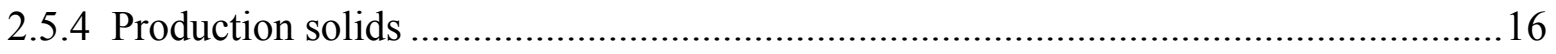

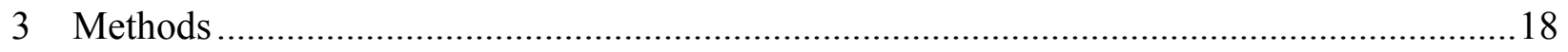

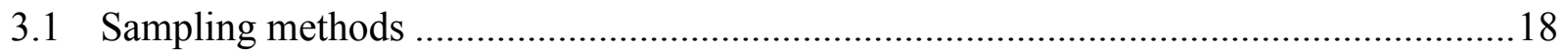

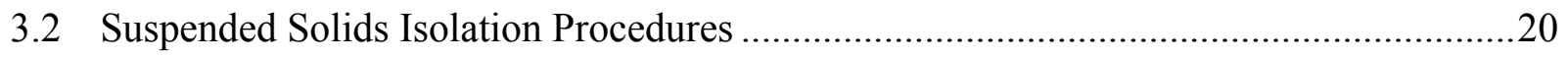




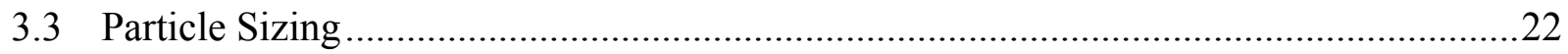

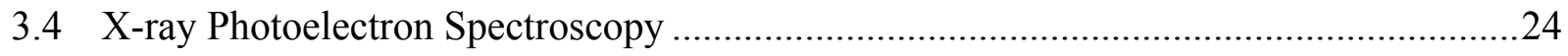

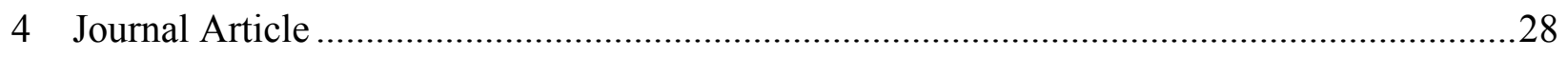

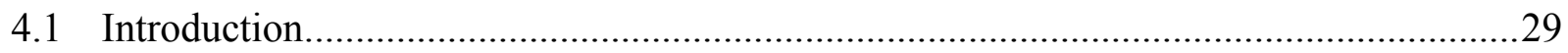

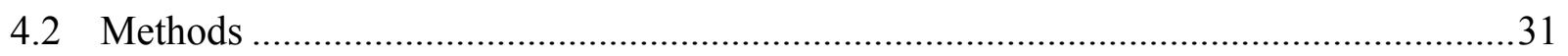

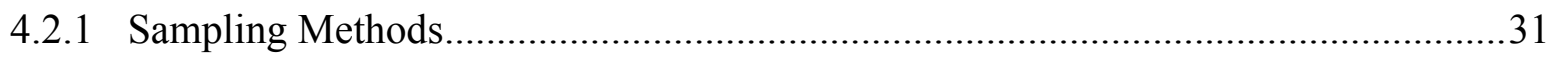

4.2.2 Gravimetric analyses and produced water quality ………....................................... 32

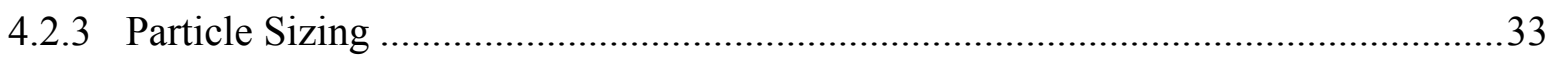

4.2.4 X-ray Photoelectron Spectroscopy (XPS) ………....................................................3

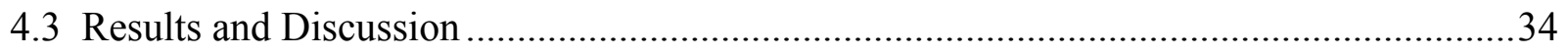

4.3.1 Produced Water Quality and Solids Distribution .......................................................34

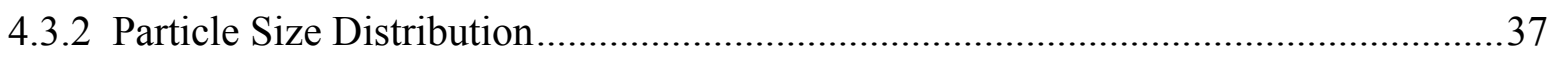

4.3.3 X-ray Photoelectron Spectroscopy (XPS) ................................................................

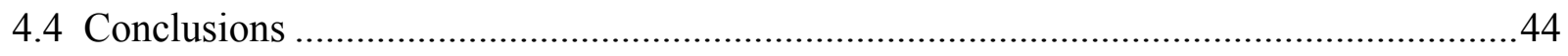

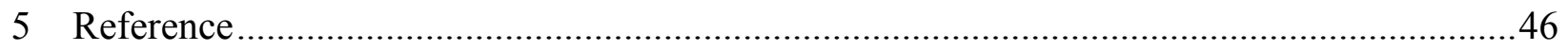

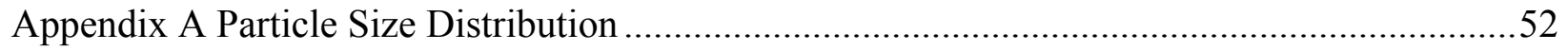

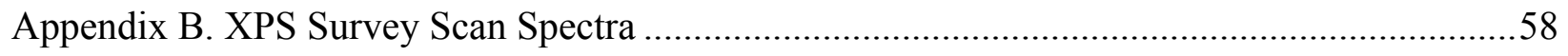




\section{LIST OF TABLES}

Table 2-1. 2000-2014 U.S annual oil and gas production .................................................. 3

Table 2-2. Chemical additives in shale gas extraction (Bishop, n.d) ....................................... 7

Table 2-3. Average water usage and water demand for major shale plays (Acharya et al., 2011)10

Table 2-4. Produced water generation for major geologic basins (Benko, 2008) ......................12

Table 2-5. Summary of Marcellus Shale Produced Water Quality (Barbot et al., 2013)............14

Table 2-6. Organic Material in Produced Water from Oil Operations (Guerra et al., 2011) ........15

Table 3-1. Sampling Schedule from wells in Crow Creek and Chandler State Pads ...................18

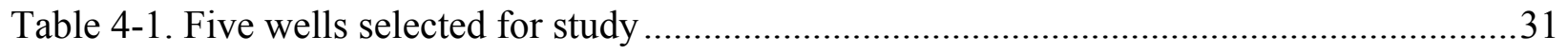

Table 4-2. Water Quality Summary for Crow Creek and Chandler State Wells..........................35

Table 4-3.Atomic Percentage of All Elements for Chandler State Wells 72-1 HN, 73-1 HN and

74-1 HN, from Day 1 to Day 20 of production 


\section{LIST OF FIGURES}

Figure 2-1. Map of U.S. shale gas and shale oil plays (EIA, 2015c).....

Figure 2-2. Permeability range of producing formations, showing where fracturing is required

(King, G. E., 2012) .5

Figure 2-3. Wellbore of horizontal well A sees more exposure to producing formation than that of vertical well B (King and Morehouse, 1993).....

Figure 2-4. Flowback and produced water flow rates in the Marcellus shale. Blue points refer to

"Flowback" and the red points refer to "Produced water." (Acharya et al., 2011)..............11

Figure 2-5. Water management components of a typical shale gas well (Ziemkiewicz, 2014)....13

Figure 2-6. Size distribution of Contaminants in Urban Wastewater (Azema et al., 2002)........16

Figure 3-1. Sample collection from wellhead ........................................................................ 19

Figure 3-2. Sample collection from production separator ................................................. 19

Figure 3-3. Suspended solid isolation steps: (a) raw produced water added to the flat crucible; (b) dried at $105{ }^{\circ} \mathrm{C}$; (c) burned at $550{ }^{\circ} \mathrm{C}$; (d) ground into fine power; (e) filtered through $0.2-$ $\mu \mathrm{m}$ silver filter.

Figure 3-4. Brookhaven Instruments 90-Plus Particle Size Analyzer

(brookhaveninstruments.com)

Figure 3-5. Different representation models for particle size distribution of study sample CC73-

1-Day 1: (a) Lognormal Size Distribution (LSD) and (b) Multimodal Size Distribution

(MSD)

Figure 3-6. Schematic of a typical, modern high resolution X-ray photoelectron spectrometer

(Haasch, 2014) .25

Figure 3-7. PEI-5800 XPS-Auger spectrometer system .26 
Figure 4-1. Location of wells within the Chandler State and Crow Creek pads

Figure 4-2. Solids distribution for Chandler State wells on Day 6 and Day 20 and Crow Creek wells on Day 6 and Day 21. The lower table summarizes the volatile portion of solids in each category.

Figure 4-3. A summary of effective particle sizes for Crow Creek and Chandler State wells (Day -2 and Day -1 day represent the pre-flow period before production, and Day 1 refers to the

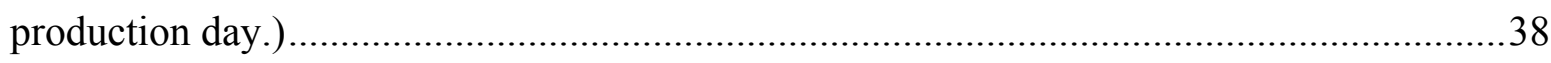

Figure 4-4. Particle size distribution (PSD) for Crow Creek and Chandler State wells .39

Figure 4-5. Temporal trending of oxygen, carbon, silicon and magnesium in samples from Chandler State wells 72-1 HN, 73-1 HN and 74-1 HN, from Day 1 to Day 20 of production.

Figure 4-6. Core-level XPS spectra for isolated suspended solids from well CS 72-1 at Day 20:

(a) C 1s, (b) O 1s, (c) Fe 2p $p_{3 / 2}$, (d) Si 2p and (e) Ca 2p 43 


\section{Introduction}

As hydraulic fracturing and horizontal drilling technologies are increasingly applied to unlock the tremendous potential in tight shale plays, a significant amount of water is used in the drilling and, in particular, the fracturing process. The produced water generated during hydraulic fracturing and then separated from the oil and gas products is becoming the largest waste stream in the industry: about 30 percent of this fracturing fluid flows back as wastewater in the first month of production. Instead of disposing this wastewater through deep well injection, oil and gas producers are making the effort to reuse produced water as the base for new fracturing fluid. The make-up of this produced water can be complex and can include emulsified oil and grease, suspended and dissolved solids, heavy metals, and chemical additives from fracturing fluid mixtures formulated to enhance oil and gas recovery. Produced water composition also can vary significantly between different geographic locations and formation properties. Knowing the quality of produced water provides more insight for potential beneficial reuse and helps optimize the treatment necessary for such reuse.

In this study, a comprehensive characterization of the suspended solids in produced water was completed. Produced water samples were collected from five wells at the Crow Creek and Chandler State pads in the Wattenberg Field of Northern Colorado. Gravimetric analyses identified the total dissolved solids (TDS), total suspended solids (TSS), and the volatile potion of each solids category. Particle sizes and distribution were measured using a dynamic light scattering method and results analyzed. Suspended solids were successfully isolated and characterized with X-ray photoelectron spectroscopy. 
Chapter 2 of this paper provides an overview of technology advances in unconventional oil and gas development. Previous work on produced water characterization is discussed, and gaps in the knowledge of this subject matter are identified.

Chapter 3 provides additional information on sampling methods and experimental procedures. The underlying principles of particle sizing and X-ray photoelectron spectroscopy (XPS) are also discussed. Full method descriptions are also available in the method section of chapter 4 .

Chapter 4 includes a journal paper prepared for submission to the journal of Energy \& Fuel. The article was reformatted to fit the thesis-formatting requirements. This paper includes a brief introduction section, full method descriptions, and a summary of results and discussions section.

Raw data on particle sizing and XPS spectra are included in Appendix A and Appendix B, respectively. 


\section{Literature Review}

\subsection{Unconventional Oil and Gas Development}

Oil and gas are the main sources of energy worldwide. The U.S. Energy Information Administration (EIA, 2014) estimated that 65 percent of energy consumption in the U.S. comes from oil and natural gas sources and projected that domestic demand for fossil fuel will remain high through 2040. By accommodating its growing energy demand, the U.S. saw in 2009 its first growth in annual oil production since 1991; and since 2012, the country has led the world in petroleum and natural gas production (Doman, 2015) (Table 2-1).

Table 2-1. 2000-2014 U.S annual oil and gas production

\begin{tabular}{ccc}
\hline Year & $\begin{array}{c}\text { Crude oil } \\
\text { production } \\
\text { (MMbbl/d) }\end{array}$ & $\begin{array}{c}\text { Dry natural gas } \\
\text { production (tcf) }\end{array}$ \\
\hline 2000 & 5.822 & 19.182 \\
2001 & 5.801 & 19.616 \\
2002 & 5.744 & 18.928 \\
2003 & 5.649 & 19.099 \\
2004 & 5.441 & 18.591 \\
2005 & 5.181 & 18.051 \\
2006 & 5.088 & 18.504 \\
2007 & 5.077 & 19.266 \\
2008 & 5.000 & 20.159 \\
2009 & 5.350 & 20.624 \\
2010 & 5.482 & 21.315 \\
2011 & 5.645 & 22.901 \\
2012 & 6.497 & 24.033 \\
2013 & 7.461 & 24.333 \\
2014 & 8.663 & 25.718 \\
\hline Data source: EIA, 2015a; EIA, 2015b
\end{tabular}

The main U.S. oil growth margin is identified as coming from tight shale formation development. Tight oil production has increased dramatically from less than 1 million barrels 
per day (MMbbl/d) in 2010 to more than $3 \mathrm{MMbbl} / \mathrm{d}$ in 2013 (EIA, 2014). Further, BP Energy (2014) projected that U.S. tight oil output will increase by about $3 \mathrm{MMbbl} / \mathrm{d}$ to more than $5 \mathrm{MMbbl} / \mathrm{d}$ in 2035.

In 2013, U.S. crude oil and lease condensate proved reserves increased to 36.5 billion barrels, reflecting a five-year increase and a 9.3 percent increase from the 2012 estimate. The Bakken/Three Forks play and Eagle Ford play (Figure 2-1) are the largest tight oil plays in the United States, with proved reserves of 4844 and 4177 million barrels of crude oil, as of 2013, respectively. The study detailed in this report focused on the area of the Denver-Julesburg basin (Niobrara formation), located in Northern Colorado.

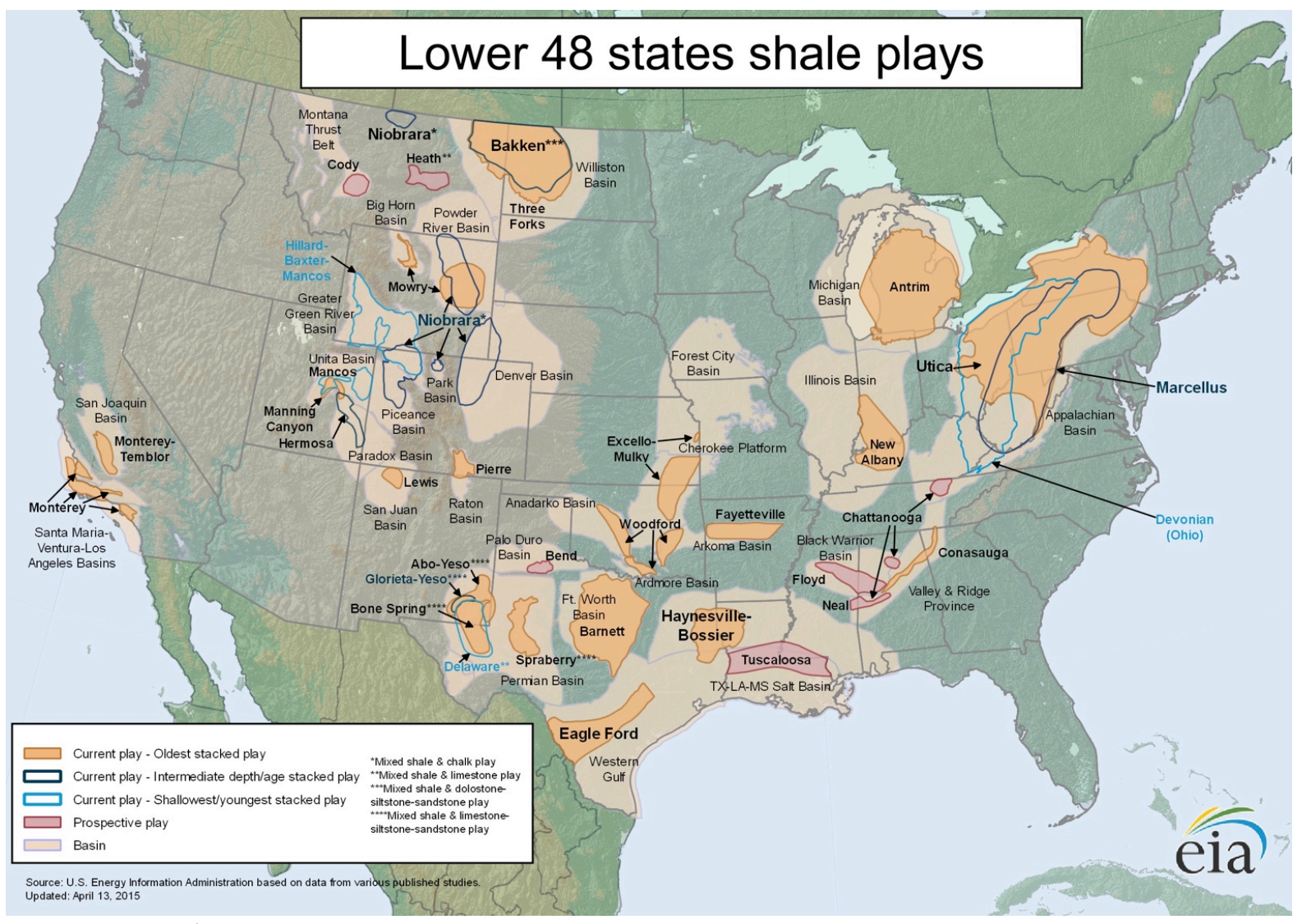

Figure 2-1. Map of U.S. shale gas and shale oil plays (EIA, 2015c) 


\subsection{Hydraulic Fracturing and Horizontal Drilling}

A hydrocarbon-bearing formation with dispersed oil and gas content is considered "unconventional" (Lechtenböhmer et al., 2011). The oil content per rock volume ratio in these formations is so small that a conventional vertical well will have only limited access to the reservoir, and it will not produce an economic flow. Another distinct characteristic is the low permeability of the shale formation. Shale rock is a clay-rich, fine-grained sedimentary source rock that contains matured hydrocarbon and natural gas. The permeability of a shale tight formation is usually in the range of 0.1- 0.0001 millidarcies (md) (Figure 2-2).

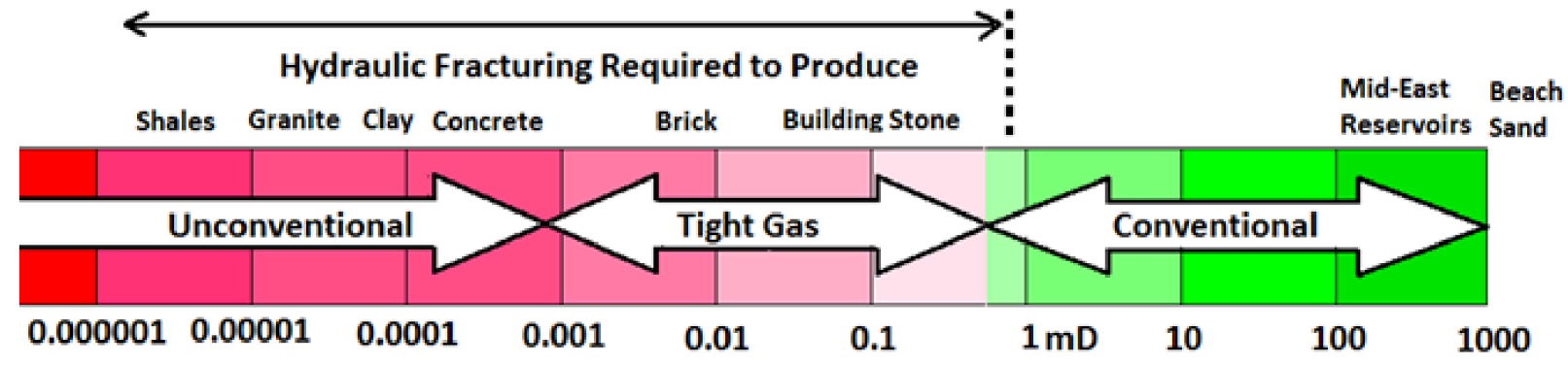

Figure 2-2. Permeability range of producing formations, showing where fracturing is required (King, G. E., 2012)

Horizontal drilling technology has expanded reservoir access, and hydraulic fracturing is now employed to open up small fractures through the tight shale formation. Wells are drilled vertically to the target depth (usually 2000-6500 ft) and then gradually turned to a horizontal direction within oil-bearing strata. Wells can extend up to one mile horizontally (Figure 2-3).

Horizontal drilling also has changed well siting and construction management practices. Locations of vertical wells often are scattered over the field and constructed separately. However, wells drilled horizontally can be arranged in a condensed area and constructed all at once--an approach that will significantly reduce production, waste management, and 
transportation costs as well as environmental impact by reducing surface area footprint and disturbance.

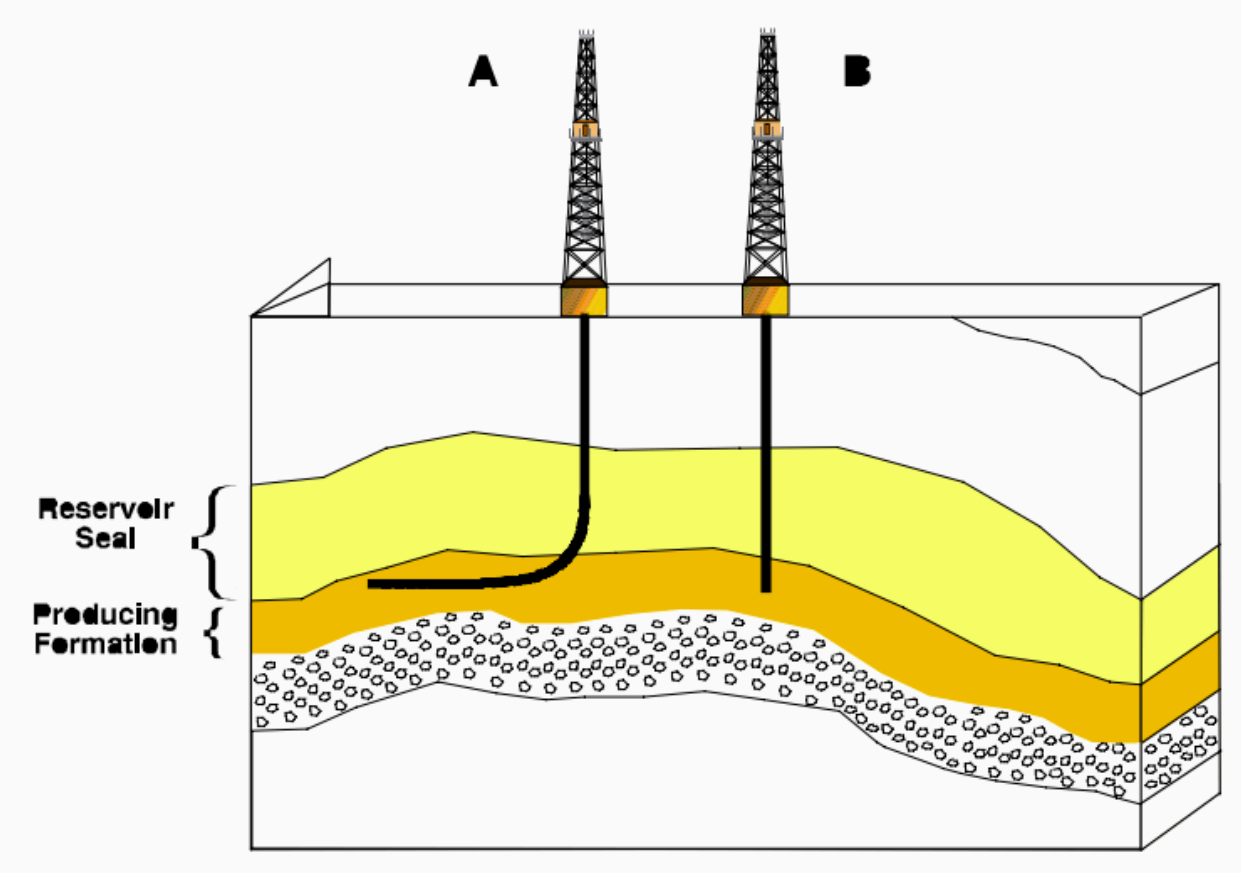

Figure 2-3. Wellbore of horizontal well A sees more exposure to producing formation than that of vertical well B (King and Morehouse, 1993)

High-pressure fracturing fluid, composed of freshwater (90\%), sand (9.5\%), and chemical additives $(0.5 \%)$, is injected into the wellbore to create and maintain fissure systems that allow trapped hydrocarbons to flow throughout. Table 2-2 lists some of the chemical additives and their intended purposes. Ingredients such as sand and cross-linked gel could contribute to suspended solids as they flow back to surface. Also, surfactant creates oil-in-water emulsions, requiring demulsifier to promote coalescence during the produced water treatment process. 
Table 2-2. Chemical additives in shale gas extraction (Bishop, n.d)

\begin{tabular}{|l|l|l|l|}
\hline Additive Type & \multicolumn{1}{|c|}{ Examples } & \multicolumn{1}{c|}{ Purpose } & \multicolumn{1}{c|}{ Used In } \\
\hline Friction Reducer & $\begin{array}{l}\text { heavy naphtha, polymer } \\
\text { microemulsion }\end{array}$ & $\begin{array}{l}\text { lubricate drill head, } \\
\text { penetrate fissures }\end{array}$ & $\begin{array}{l}\text { drilling muds, } \\
\text { fracturing fluids }\end{array}$ \\
\hline Biocide & $\begin{array}{l}\text { glutaraldehyde, DBNPA, } \\
\text { dibromoacetonitrile }\end{array}$ & $\begin{array}{l}\text { prevent biofilm } \\
\text { formation }\end{array}$ & $\begin{array}{l}\text { drilling muds, } \\
\text { fracturing fluids }\end{array}$ \\
\hline Scale Inhibitor & $\begin{array}{l}\text { ethylene glycol, EDTA, } \\
\text { citric acid }\end{array}$ & $\begin{array}{l}\text { prevent scale } \\
\text { buildup }\end{array}$ & $\begin{array}{l}\text { drilling muds, } \\
\text { fracturing fluids }\end{array}$ \\
\hline $\begin{array}{l}\text { Corrosion } \\
\text { Inhibitor }\end{array}$ & $\begin{array}{l}\text { propargyl alcohol, } \\
\text { N,N-dimethylformamide }\end{array}$ & $\begin{array}{l}\text { prevent corrosion } \\
\text { of metal parts }\end{array}$ & $\begin{array}{l}\text { drilling muds, } \\
\text { fracturing fluids }\end{array}$ \\
\hline Clay Stabilizer & $\begin{array}{l}\text { tetramethylammonium } \\
\text { chloride }\end{array}$ & $\begin{array}{l}\text { prevent clay } \\
\text { swelling }\end{array}$ & $\begin{array}{l}\text { drilling muds, } \\
\text { fracturing fluids }\end{array}$ \\
\hline Gelling Agent & $\begin{array}{l}\text { bentonite, guar gum, } \\
\text { "gemini quat" amine }\end{array}$ & $\begin{array}{l}\text { prevent slumping } \\
\text { of solids }\end{array}$ & $\begin{array}{l}\text { drilling muds, } \\
\text { fracturing fluids }\end{array}$ \\
\hline Conditioner & $\begin{array}{l}\text { ammonium chloride, } \\
\text { potassium carbonate, } \\
\text { isopropyl alcohol }\end{array}$ & $\begin{array}{l}\text { adjust pH, } \\
\text { adjust additive } \\
\text { solubility }\end{array}$ & $\begin{array}{l}\text { drilling muds, } \\
\text { fracturing fluids }\end{array}$ \\
\hline Surfactant & $\begin{array}{l}\text { 2-butoxyethanol, } \\
\text { ethoxylated octylphenol }\end{array}$ & $\begin{array}{l}\text { promote fracture } \\
\text { penetration }\end{array}$ & $\begin{array}{l}\text { drilling fluids, } \\
\text { fracturing fluids }\end{array}$ \\
\hline Cross-Linker & $\begin{array}{l}\text { sodium perborate, } \\
\text { acetic anhydride }\end{array}$ & promote gelling & fracturing fluids \\
\hline Breaker & $\begin{array}{l}\text { hemicellulase, } \\
\text { ammonium persulfate, } \\
\text { quebracho }\end{array}$ & $\begin{array}{l}\text { "breaks" gel to } \\
\text { promote flow-back } \\
\text { of fluid }\end{array}$ & $\begin{array}{l}\text { post-fracturing } \\
\text { fluids }\end{array}$ \\
\hline Cleaner & hydrochloric acid & dissolve debris & $\begin{array}{l}\text { stimulation fluid, } \\
\text { pre-fracture fluid }\end{array}$ \\
\hline Processor & $\begin{array}{l}\text { ethylene glycol, } \\
\text { propylene glycol }\end{array}$ & $\begin{array}{l}\text { strip impurities } \\
\text { from produced gas }\end{array}$ & $\begin{array}{l}\text { post-production } \\
\text { processing fluids }\end{array}$ \\
\hline
\end{tabular}

\subsection{Economic and Environmental Impacts}

\subsubsection{Economic Impact}

After the financial crisis in 2007 that caused weak economic growth and a high unemployment rate, the shale gas revolution provided a strong boost for the U.S. economy. The booming shale gas production has brought adequate supply and low energy prices to production and manufacturing industries, stimulating the U.S. economic recovery in the manufacturing 
sector. The production growth of crude oil and natural gas also gradually reduced foreign oil imports, which strengthened U.S. energy independency.

According to a report from IHS Global Insight (2011), the main economic benefits of the U.S. shale gas revolution are as follows:

- The first benefit is the promotion of economic growth and an increase in the employment rate. In 2010 alone, shale gas-related industries realized a $\$ 760$ billion GDP and more than 600,000 new jobs; this growth is expected to continue in the future.

- The second benefit is the creation of additional tax revenue. Shale gas-related industries contributed $\$ 18.6$ billion of tax at local, state, and federal government levels in the year of 2010 .

- Thirdly, unconventional shale development can reduce energy costs and enhance the competitiveness of related industries. In 2011, drilling costs of unconventional gas wells saw a 40 to 50 percent reduction, compared to conventional natural gas wells. In the mean time, lower natural gas prices decreased electricity prices for industries by 10 percent and allowed a 2.9 percent increase in industrial production.

\subsubsection{Environmental impacts}

The growth of unconventional drilling activities throughout major basins in the U.S. has raised public concerns regarding environmental and public health related issues. Proper risk management and the application of best engineering practices are expected to help mitigate these threads. Environmental impacts of shale oil and gas development could include:

(1) Water pollution. The large water demand of shale gas extraction could intensify competition of water resources, especially in water-scarce areas. A report from the International 
Energy Agency (IEA) noted that harmful substances could penetrate or spill into the underground aquifer and contaminate sources of drinking water; natural gas also could dissolve into an adjacent reservoir (Birol et al., 2011). However, a report released by MIT (2011) showed that, over the past ten years, in over 20,000 or more shale gas wells nationwide, only 43 water pollution incidents were reported--an indication that ground water contamination can be controlled and the risk of such can be minimized.

(2) Air pollution and greenhouse gas emissions. Natural gas can be considered a transition from coal-based energy to a future, renewable energy form. Natural gas is much cleaner than coal, typically emitting low sulfur dioxide, carbon monoxide and fine particles (PM 2.5 and PM 10). Notwithstanding, natural gas does contribute to global greenhouse emissions; with the greenhouse effect of methane being 25 times larger than $\mathrm{CO} 2$, a possible natural gas leak through gas extraction and transportation can contribute significantly to the greenhouse effect (Riemer, 1996).

(3) Small earthquakes. Hydraulic fracturing and deep-well injection can increase the possibility of small earthquakes. Although a strong cause-effect relationship has not been established, the increase of small earthquakes with active hydraulic fracturing activities has been recorded since the 1980s (Fehler et al., 1987;Sasaki, 1998). The U.S. Department of Geological Survey (USGS) has noted that the number of recorded earthquakes with $M \geq 3$ was five times greater in 2011 and 2012, compared to the yearly rate from 2000 to 2010 and that most were injection-induced earthquakes (Ellsworth, 2013). 


\subsection{Water Management}

\subsubsection{Water Demand}

The water demand of well development primarily consists of two parts: drilling/well completion and reservoir stimulation (hydraulic fracturing). The water usage rate can vary significantly, for both drilling/well completion and reservoir stimulation, depending on the well type. Water-based drilling mud, consisting primarily of clay and chemical additives, is used to cool drill bits and carry rock cuttings to the surface. Vertical and directional wells are shorter than horizontal wells; thus, they use less water in drilling than a typical horizontal well, which requires a maximum of 600,000 gallons of water for drilling (COGA, 2015).

For hydraulic fracturing, a vertical well uses 100,000 to $1,000,000$ gallons of water, if a stimulation step is included; in comparison, whereas a horizontal well uses 2 to 5 million gallons, depending on the length and the number of fracture stages. Table 2-2 summarizes average water usage per well for drilling and fracturing process and provides a rough estimate of total water demand. In the Wattenberg field, water use was estimated between 2.8 and 6.5 million gallons per well, respectively, for horizontal wells and extended horizontal wells that have fracture stages greater than 25 (Goodwin et al. 2013).

Table 2-3. Average water usage and water demand for major shale plays (Acharya et al., 2011)

\begin{tabular}{|c|c|c|c|c|c|}
\hline & \multicolumn{3}{|c|}{ Average water usage (bbls/well) } & \multirow{2}{*}{ Wells/year } & \multirow{2}{*}{$\begin{array}{c}\text { Water } \\
\text { demand } \\
\text { MMbbls/year }\end{array}$} \\
\hline & Drilling & Fracturing & Total & & \\
\hline Barnett & 10,000 & 70,000 & 80,000 & 600 & 48 \\
\hline Fayetteville & 1,500 & 70,000 & 71,500 & 250 & 18 \\
\hline Haynesville & 25,000 & 65,000 & 90,000 & 200 & 18 \\
\hline Marcellus & 2,000 & 90,000 & 92,000 & 600 & 55 \\
\hline
\end{tabular}




\subsubsection{Wastewater Production}

The water that separates from hydrocarbon products at the surface is referred to as "flowback" or "produced water." In the early stage of well production, waste water flowing back consists primarily of fracturing fluid, broken cross linkers, chemical additives, clays, dissolved metal ions, and high levels of TDS and TSS. This "flowback" water has a high flow rate, and its water quality changes rapidly on a daily basis. As the well cleans itself up and the injected fracturing fluid reaches equilibrium with the formation, wastewater primarily contains dissolved organic matters and high levels of TSS and TDS, with elevated concentrations of magnesium, calcium, barium, and iron. Produced water flows throughout the extent of production, and flow rate gradually decreases until stabilized (Figure 2-4). However, the transition between flowback and produced water is not well defined. Generally, the flowback period takes a few days to several weeks.

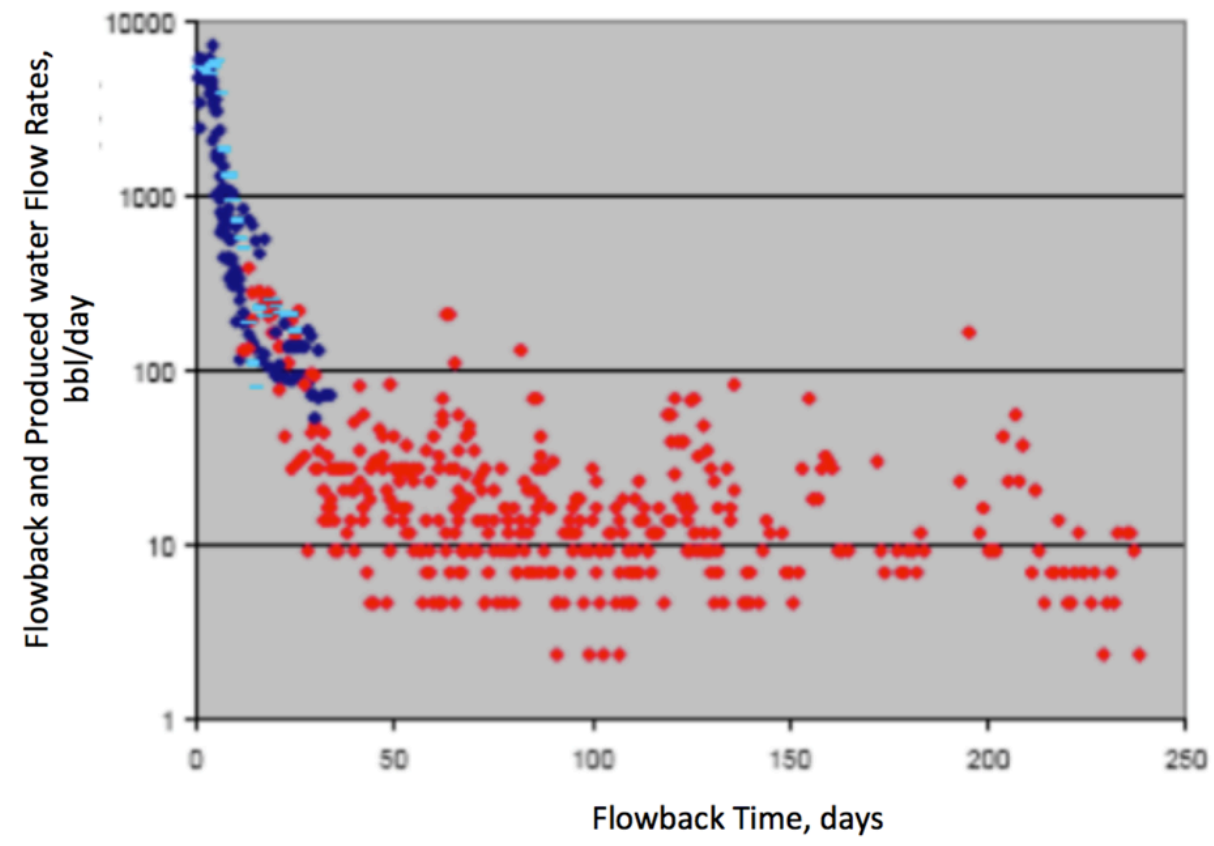

Figure 2-4. Flowback and produced water flow rates in the Marcellus shale. Blue points refer to "Flowback" and the red points refer to "Produced water." (Acharya et al., 2011) 
The estimated amount of produced water generated in the United States is between $6.1 \times 10^{6} \mathrm{~m}^{3} /$ day and $7.8 \times 10^{6} \mathrm{~m}^{3} /$ day $(1,600$ and 2,060 million gallons/day) (Benko, 2008). Table 2-4 showed produced water generation for major geologic basins and the treatability potentials were categorized based on TDS concentrations.

Table 2-4. Produced water generation for major geologic basins (Benko, 2008)

\begin{tabular}{lcccl}
\hline & \multicolumn{3}{c}{ Water production } \\
Geologic basin & $m^{3} /$ day & $\begin{array}{c}\text { Median TDS } \\
\text { ma day }\end{array}$ & $\begin{array}{c}\text { Potential for } \\
(m g / L)^{\mathrm{b}}\end{array}$ & treatment \\
\hline Williston & 18,000 & 4.9 & 132,400 & Low \\
Powder River & 370,000 & 97 & 7,300 & Very high \\
Big Horn & 360,000 & 94 & 4,900 & Very high \\
Wind River & 54,000 & 14 & 5,300 & Very high \\
Green River & 41,000 & 11 & 9,400 & High \\
Denver & 14,000 & 3.8 & 10,200 & High \\
Uinta-Piceance & 42,000 & 11 & 13,200 & High \\
Paradox & 21,000 & 5.6 & 67,000 & Low \\
San Juan & 14,000 & 3.6 & 22,700 & Medium \\
Anadarko & 34,000 & 8.9 & 132,200 & Very low \\
Permianc & 250,000 & 65 & 89,200 & Low \\
San Joaquin & NA & NA & 22,700 & Medium \\
Los Angeles & NA & NA & 30,330 & Medium \\
\hline
\end{tabular}

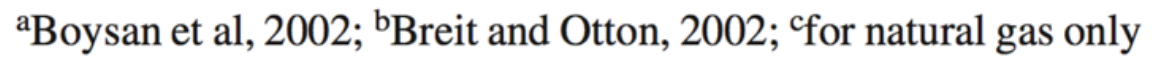
and for the New Mexico portion of the Permian Basin.

A study (Ziemkiewicz, 2014) reported that, in the Marcellus field, about 10 to 30 percent of injected fracturing fluid returns to the surface and about 80 percent of that returned fluid is recycled as makeup water in subsequent fracturing activities. The remaining 20 percent of produced water is generally disposed of through deep-well injection (Figure 2-5). 


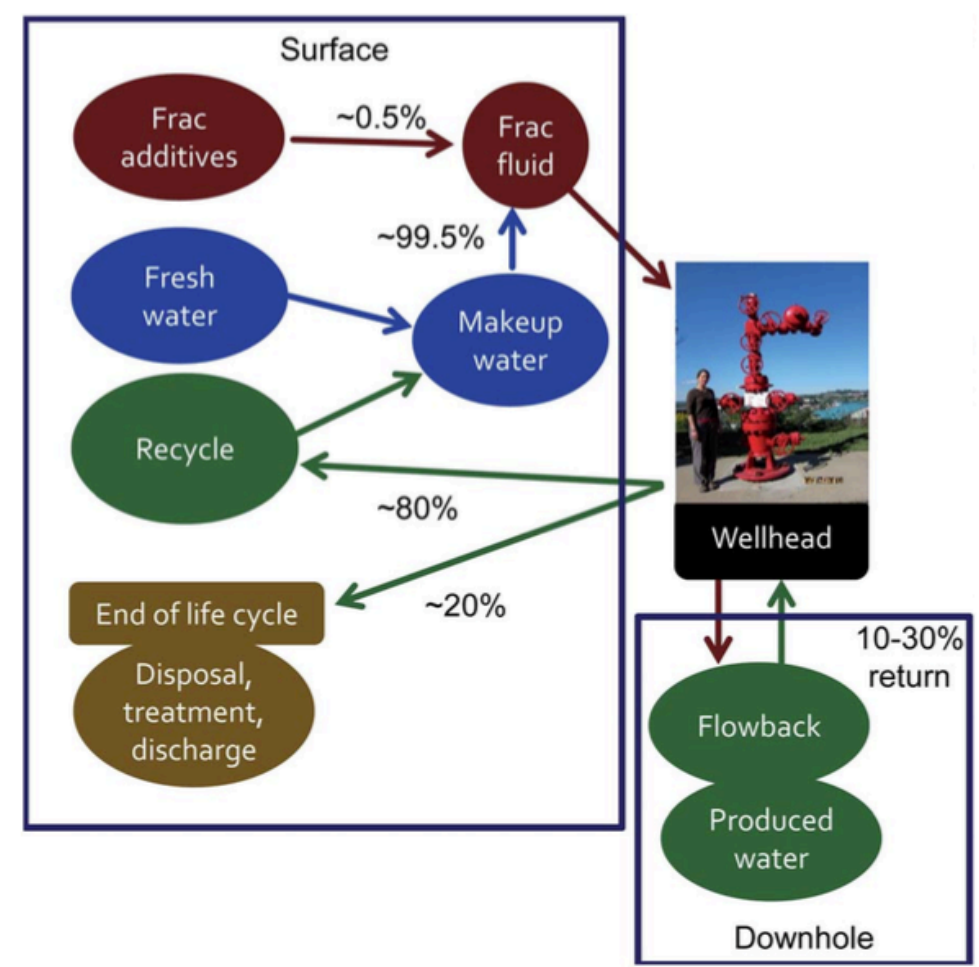

Figure 2-5. Water management components of a typical shale gas well (Ziemkiewicz, 2014)

\subsection{Characteristics of Produced Water}

Because produced water comes in contact with underground formation/brine water and dissolved minerals, it presents a complicated and highly variable water quality. The components of produced water can be categorized as inorganic salts, organic constituents, production solids, and naturally occurring radioactive material (NORM).

\subsubsection{Inorganic salts}

Inorganic constituents originate primarily from dissolved formation minerals. While the dominant salt in most produced water is sodium chloride, other cations such as $\mathrm{K}^{+}, \mathrm{Ca}^{2+}, \mathrm{Mg}^{2+}$, $\mathrm{Sr}^{2+}, \mathrm{Ba}^{2+}, \mathrm{Fe}^{3+}$ and anions such as $\mathrm{Cl}^{-}, \mathrm{SO}_{4}{ }^{2-}, \mathrm{CO}_{3}{ }^{2-}$ and $\mathrm{HCO}_{3}{ }^{-}$can be present. Total dissolved solids (TDS) concentration in produced water ranges from $1,000 \mathrm{mg} / \mathrm{L}$ to more than 400,000 $\mathrm{mg} / \mathrm{L}$ (Benko and Drewes, 2008). Sulfate concentration in produced water is usually lower than 
that of seawater. An inorganic water quality summary from the Marcellus shale is provided in Table 2-5.

Table 2-5. Summary of Marcellus Shale Produced Water Quality (Barbot et al., 2013)

\begin{tabular}{|c|c|c|c|c|}
\hline & minimum & maximum & average & $\begin{array}{c}\text { number of } \\
\text { samples }\end{array}$ \\
\hline TDS (mg/L) & 680 & 345,000 & 106,390 & 129 \\
\hline TSS (mg/L) & 4 & 7,600 & 352 & 156 \\
\hline oil and grease $(\mathrm{mg} / \mathrm{L})$ & 4.6 & 802 & 74 & 62 \\
\hline $\mathrm{COD}(\mathrm{mg} / \mathrm{L})$ & 195 & 36,600 & 15,358 & 89 \\
\hline TOC (mg/L) & 1.2 & 1530 & 160 & 55 \\
\hline $\mathrm{pH}$ & 5.1 & 8.42 & 6.56 & 156 \\
\hline $\begin{array}{l}\text { alkalinity }(\mathrm{mg} / \mathrm{L} \text { as } \\
\left.\mathrm{CaCO}_{3}\right)\end{array}$ & 7.5 & 577 & 165 & 144 \\
\hline $\mathrm{SO}_{4}(\mathrm{mg} / \mathrm{L})$ & 0 & 763 & 71 & 113 \\
\hline $\mathrm{Cl}(\mathrm{mg} / \mathrm{L})$ & 64.2 & 196,000 & 57,447 & 154 \\
\hline $\mathrm{Br}(\mathrm{mg} / \mathrm{L})$ & 0.2 & 1,990 & 511 & 95 \\
\hline $\mathrm{Na}(\mathrm{mg} / \mathrm{L})$ & 69.2 & 117,000 & 24,123 & 157 \\
\hline $\mathrm{Ca}(\mathrm{mg} / \mathrm{L})$ & 37.8 & 41,000 & 7,220 & 159 \\
\hline $\mathrm{Mg}(\mathrm{mg} / \mathrm{L})$ & 17.3 & 2,550 & 632 & 157 \\
\hline $\mathrm{Ba}(\mathrm{mg} / \mathrm{L})$ & 0.24 & 13,800 & 2,224 & 159 \\
\hline $\mathrm{Sr}(\mathrm{mg} / \mathrm{L})$ & 0.59 & 8,460 & 1,695 & 151 \\
\hline Fe dissolved (mg/L) & 0.1 & 222 & 40.8 & 134 \\
\hline Fe total $(\mathrm{mg} / \mathrm{L})$ & 2.6 & 321 & 76 & 141 \\
\hline gross alpha $^{a}(\mathrm{pCi} / \mathrm{L})$ & 37.7 & 9,551 & 1,509 & 32 \\
\hline $\operatorname{gross}$ beta $^{a}(\mathrm{pCi} / \mathrm{L})$ & 75.2 & 597,600 & 43,415 & 32 \\
\hline $\mathrm{Ra}^{228}(\mathrm{pCi} / \mathrm{L})$ & 0 & 1,360 & 120 & 46 \\
\hline $\mathrm{Ra}^{226}(\mathrm{pCi} / \mathrm{L})$ & 2.75 & 9,280 & 623 & 46 \\
\hline $\mathrm{U}^{235}(\mathrm{pCi} / \mathrm{L})$ & 0 & 20 & 1 & 14 \\
\hline $\mathrm{U}^{238}(\mathrm{pCi} / \mathrm{L})$ & 0 & 497 & 42 & 14 \\
\hline
\end{tabular}

\subsubsection{Organic Constituents}

Produced water typically has a total organic carbon (TOC) concentration ranging from non-detectable to $1700 \mathrm{mg} / \mathrm{L}$ (Table 2-6), with $\mathrm{pH}$ and temperature the significant factors affecting the concentration of soluble organics. Organic constituents generally fall into two categories: dissolved and dispersed. Dissolved organics are often found in low- and mediumcarbon ranges; formic acid and propionic acid are two typical compounds found in produced 
water (Fakhru'l-Razi, 2009). Benzene, toluene, ethylbenzene, and xylene (BTEX) compounds are the most common dissolved organic contents in produced water.

Table 2-6. Organic Material in Produced Water from Oil Operations (Guerra et al., 2011)

\begin{tabular}{|c|c|c|c|c|c|}
\hline \multirow[b]{2}{*}{ Constituent } & \multirow[b]{2}{*}{ Units } & \multicolumn{3}{|c|}{ Concentration Range } & \multirow{2}{*}{$\begin{array}{l}\text { Technique } \\
\text { (Method) }\end{array}$} \\
\hline & & Low & High & Median & \\
\hline TOC & $\mathrm{mg} / \mathrm{L}$ & ND & 1,700 & NA & $\begin{array}{l}\text { UV Oxidation/IR (USEPA } \\
\text { 415.1) }\end{array}$ \\
\hline COD & $\mathrm{mg} / \mathrm{L}$ & \multicolumn{2}{|c|}{1,220} & NA & $\begin{array}{l}\text { Redox Titration (USEPA } \\
410.3 \text { ) }\end{array}$ \\
\hline TSS & $\mathrm{mg} / \mathrm{L}$ & 1.2 & 1,000 & NA & Gravimetric (USEPA 160.2) \\
\hline Total Oil & $\mathrm{mg} / \mathrm{L}$ & 2 & 565 & NA & Gravimetric (USEPA 413.1) \\
\hline Volatiles & $\mathrm{mg} / \mathrm{L}$ & 0.39 & 35 & NA & $\begin{array}{l}\text { GC/MS (USEPA } 1624 \text { Rev } \\
\text { B and USEPA } 24 \& \text { CLP) }\end{array}$ \\
\hline Total Polars & $\mathrm{mg} / \mathrm{L}$ & 9.7 & 600 & NA & Florisil column/IR \\
\hline Phenols & $\mathrm{mg} / \mathrm{L}$ & 0.009 & 23 & NA & Silylation GLC/MS \\
\hline $\begin{array}{l}\text { Volatile Fatty } \\
\text { Acids }\end{array}$ & $\mathrm{mg} / \mathrm{L}$ & 2 & 4,900 & NA & Direct GLC/FID of water \\
\hline
\end{tabular}

${ }^{1} \mathrm{ND}=$ below detection limit; $\mathrm{NA}=$ not available.

Dispersed organic contents present as small droplets suspended in the produced water. Less-soluble polyaromatic hydrocarbons (PAHs) and heavy phenols are usually found in produced water as dispersed oil (Igunnu \& Chen, 2012). "The amount of dispersed oil in produced water depends on the density of oil, the shear history of the droplet, the amount of oil precipitation, and interfacial tension between the water and oil." (Fakhru'l-Razi, 2009)

\subsubsection{Naturally Occurring Radioactive Material (NORM)}

Oil-field formation water that is rich in chloride enhances the solubility of radioactive elements such as radium (Zielinski \& Otton, 1999); this radium-bearing water is extracted to the surface with oil and gas development. Radium will co-precipitate with barite (barium sulfate) 
and deposit on oil field equipment. As shown in Table $2-5,{ }^{226}$ Radium and ${ }^{228}$ Radium are the most abundant NORMs in produced water.

\subsubsection{Production solids}

A wide range of materials, including formation solids, corrosion and scale products, bacteria, waxes, and asphaltenes, make up the production solids in produced water (Fakhru'lRazi, 2009).

Suspended particulates in a dispersed aqueous system, and the effects of settling time, mass transportation, aggregation pattern and colloidal chemical reaction, have been fully studied within the context of municipal wastewater research and management. Four different size categories are usually applied to describe the pollution fractions in urban wastewater: soluble $(<0.001 \mu \mathrm{m})$; colloidal $(0.001-1 \mu \mathrm{m})$; supracolloidal $(1-100 \mu \mathrm{m})$; and settleable $(>100 \mu \mathrm{m})$ (Levine et. al.,1991). Total Suspended Solids (TSS) are those solids in supracolloid and settleable size ranges. Figure 2-4 identifies the size range of major organic compounds in municipal wastewater.

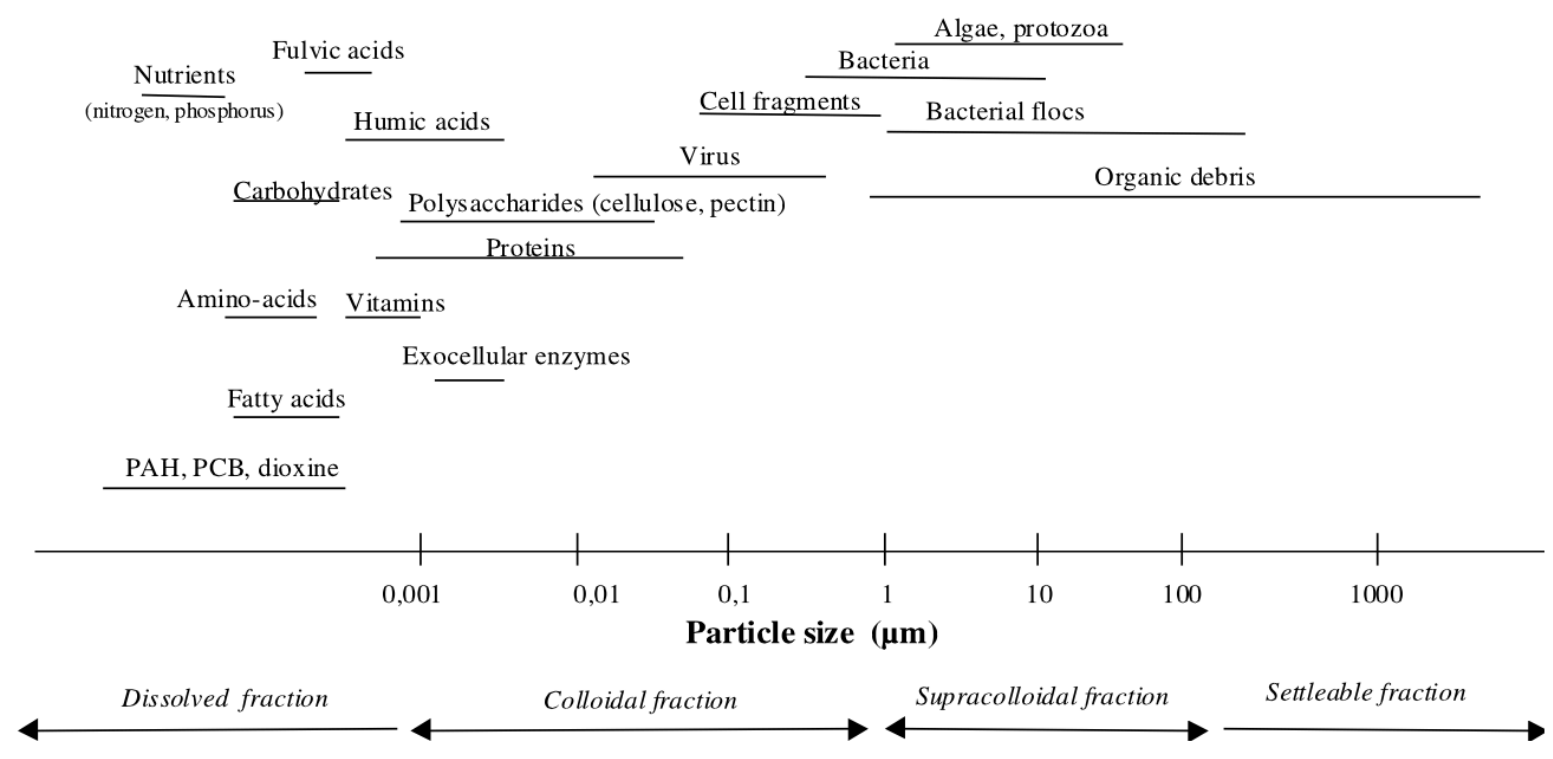

Figure 2-6. Size distribution of Contaminants in Urban Wastewater (Azema et al., 2002) 
Azema et al. compared different optical methods for characterizing wastewater suspended solids and proposed laser granulometry method for a better discrimination of supracolloids and settleable particles. A more extensive review of methods such as light scattering, differential mobility analysis, time of flight mass spectroscopy (TOF-MS), microscopy, and surface area measurements showed that the dynamic light scattering approach was preferred for nanoparticle size distribution testing in an aqueous environment (Powers et al., 2006). 


\section{Methods}

Section 3.1 and 3.2 discuss produced water sampling methods and suspended solid isolation protocols. Detailed methods and underlying principles of particle size measurement and X-ray photoelectron spectroscopy (XPS) are discussed in Sections 3.3 and 3.4. A complete method description also is provided in the method section of Chapter 4.

\subsection{Sampling methods}

Two Noble Energy Inc. well pads were studied: Crow Creek (CC) and Chandler State (CS), both located in the Wattenberg field of Northern Colorado. Five wells were selected from these two pads, and water samples were collected from each well after flowback started. Sampling schedule is summarized in Table 3-1. It should be noted that not all samples collected were tested in this study for particle size and XPS.

Table 3-1. Sampling Schedule from wells in Crow Creek and Chandler State Pads

\begin{tabular}{cccccc}
\hline \multirow{2}{*}{ Pad } & \multicolumn{5}{c}{ Sampling frequency } \\
\cline { 2 - 6 } Crow Creek & 8 hours & 12 hours & 24 hours & 3 days & 7 days \\
\hline & Day 1 to 2 & Day 3 to 5 & Day 6 to 15 & $\begin{array}{c}\text { Day } 16 \text { to } \\
24\end{array}$ & $\begin{array}{c}\text { Day } 25 \text { to } \\
37\end{array}$ \\
Chandler State & N/A & N/A & Day 1 to 14 & $\begin{array}{c}\text { Day } 15 \text { to } \\
29\end{array}$ & $\begin{array}{c}\text { Day } 30 \text { to } \\
50\end{array}$ \\
\hline
\end{tabular}

Samples were collected at the wellhead during the first few days after production when all flowback fluids were separated at the temporary oil-water separator and, after the permanent production separator was installed, samples were collected from the service valve postseparation. For the Crow Creek and Chandler State pads, the production separator was installed five and four days, respectively, after flowback started. 
Figure 3-1 illustrates the sampling method at the wellhead. Oil-water mixed fluid was collected in a five-gallon carboy and allowed to settle for 15 minutes. Produced water then was separated from crude oil through the lower spigot. When the production separator was in operation, samples were collected post oil-water separation from a service valve (Figure 3-2).

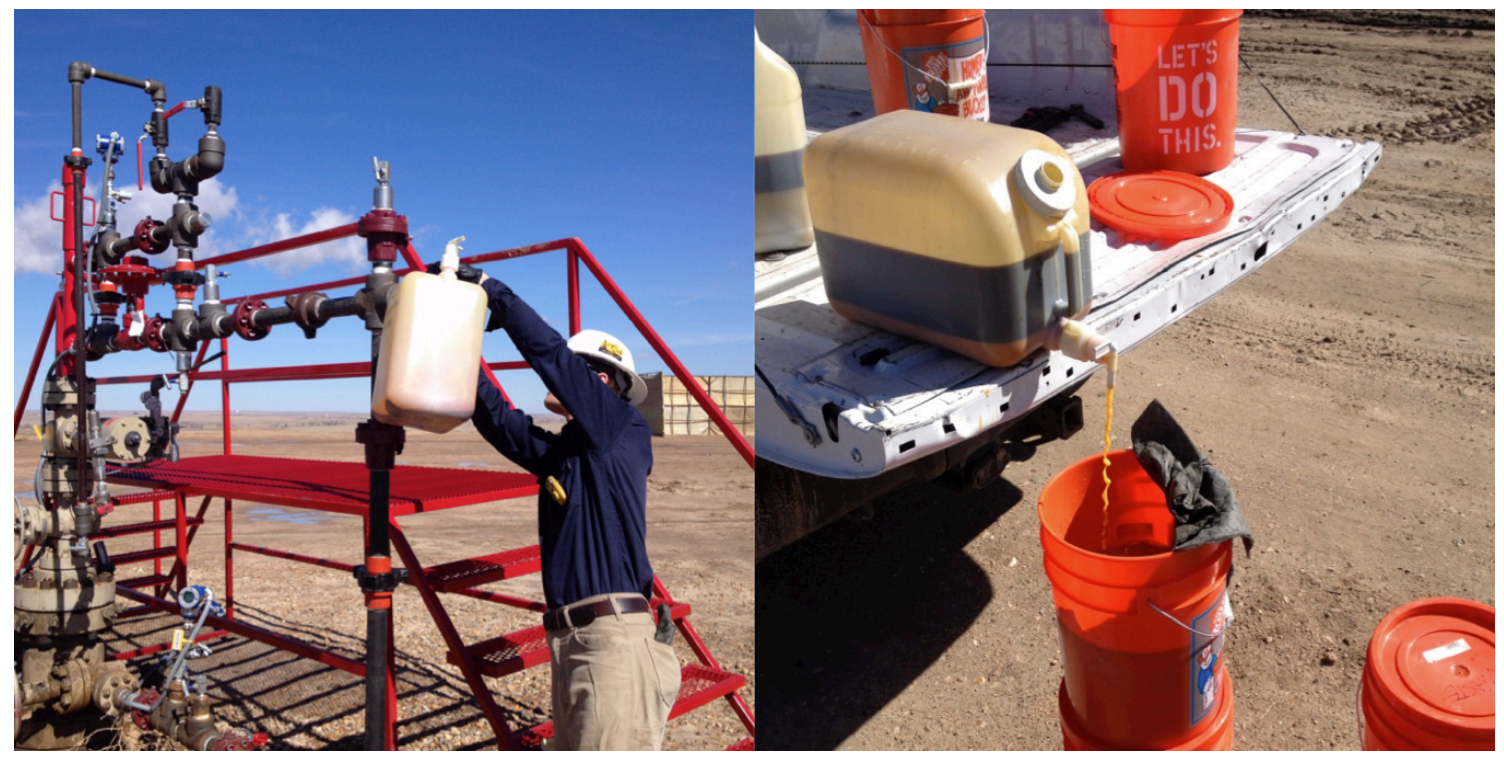

Figure 3-1. Sample collection from wellhead

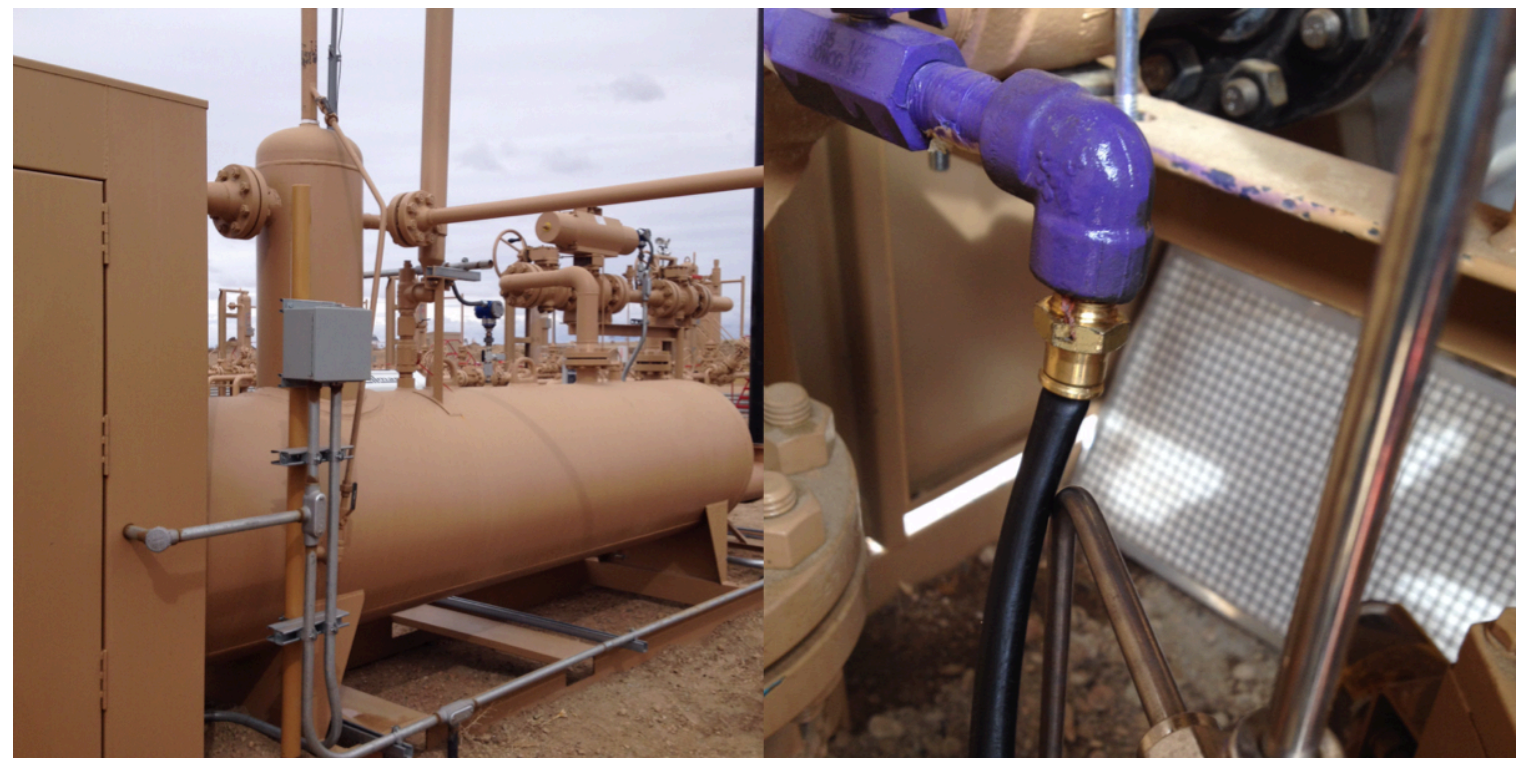

Figure 3-2. Sample collection from production separator 


\subsection{Suspended Solids Isolation Procedures}

To better capture suspended solids in produced water for XPS elemental test, a solids separation protocol was developed. The main objective of this procedure is to capture most suspended solids as well as to prepare the sample to be ultra-high-vacuum (UHV) compatible for the XPS test. Some extra steps also were also designed and applied to eliminate possible interferences. For example, because the glass fiber filter could possibly contribute interfering silicon signals in the XPS test, a silver filter was used. Further, because the sample could be contaminated by organic carbon through previously applied experiment procedures, the sample was burned at $550{ }^{\circ} \mathrm{C}$ immediately before the XPS scan.

The following preparation steps, illustrated in Figure 3-3, were applied:

(1) $50 \mathrm{~mL}$ of water sample were added to a flat crucible and dried at $105{ }^{\circ} \mathrm{C}$ and then burned at $550{ }^{\circ} \mathrm{C}$ in a muffle furnace. To collect enough solid, 200- $\mathrm{mL}$ of each sample were added to each of four crucibles.

(2) Residuals were collected and ground into a fine powder.

(3) Fine powder from Step 2 was dissolved into $200 \mathrm{~mL}$ of deionized water with a magnetic stirrer.

(4) The mixed solution was filtered through a $0.2-\mu \mathrm{m}$ silver filter (Sterlitech Corp. WA) under vacuum.

(5) The filter was then rinsed with $200 \mathrm{~mL}$ deionized water to wash off dissolved salts.

(6) The filter was furnaced again at $550{ }^{\circ} \mathrm{C}$, and the sample was tested by XPS within one hour. 


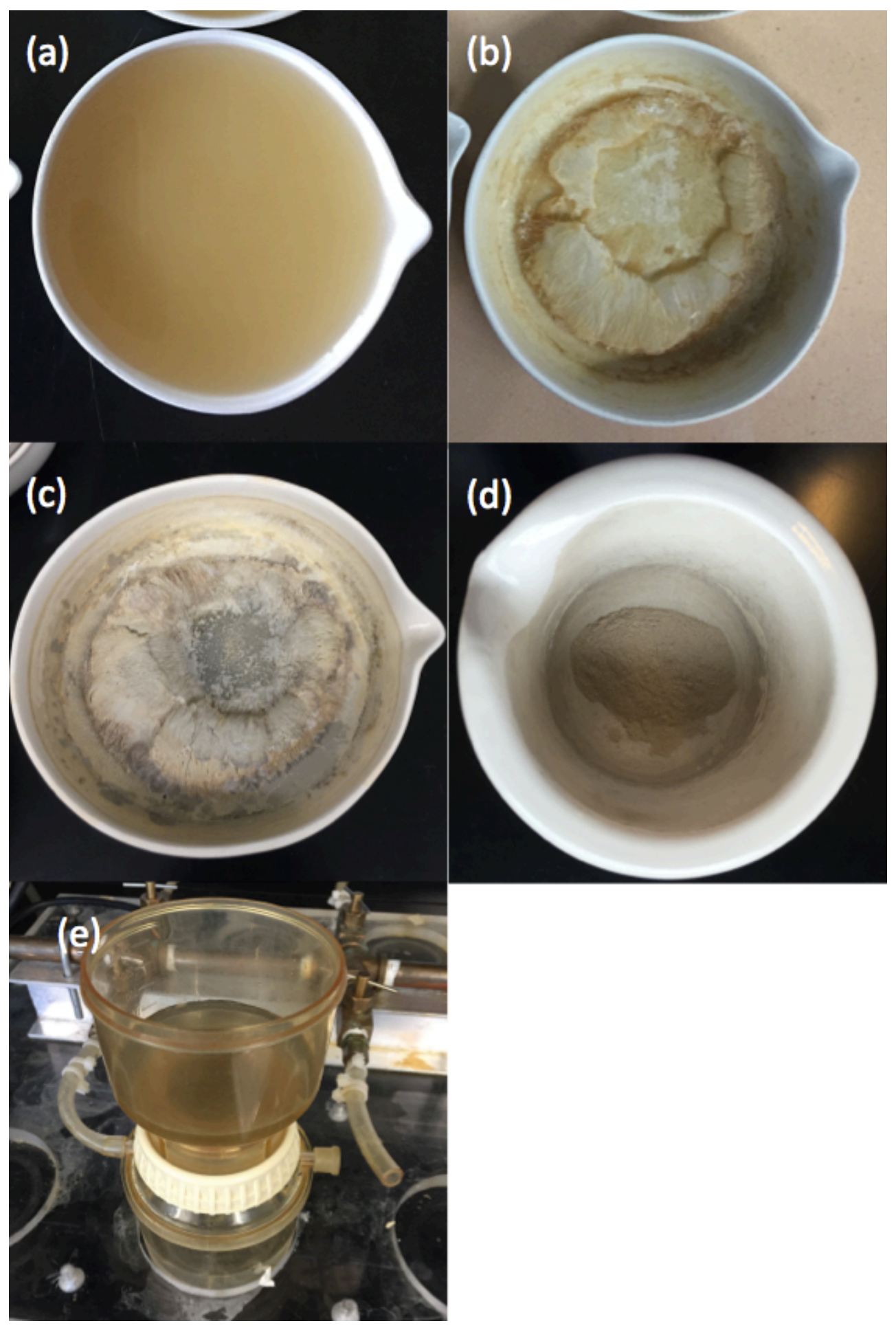

Figure 3-3. Suspended solid isolation steps: (a) raw produced water added to the flat crucible; (b) dried at $105{ }^{\circ} \mathrm{C}$; (c) burned at $550{ }^{\circ} \mathrm{C}$; (d) ground into fine powder; (e) filtered through $0.2-\mu \mathrm{m}$ silver filter. 


\subsection{Particle Sizing}

Particle size and particle size distribution (PSD) are the key properties describing colloidal and dispersed systems. In this study, a dynamic light scattering (DLS) method was applied to size particles, using a 90-Plus Particle Size Analyzer (Brookhaven Instruments, NY) at a fixed, scattering angle of $90^{\circ}$ and temperature of $25^{\circ} \mathrm{C}$ (Figure $\left.3-4\right)$.

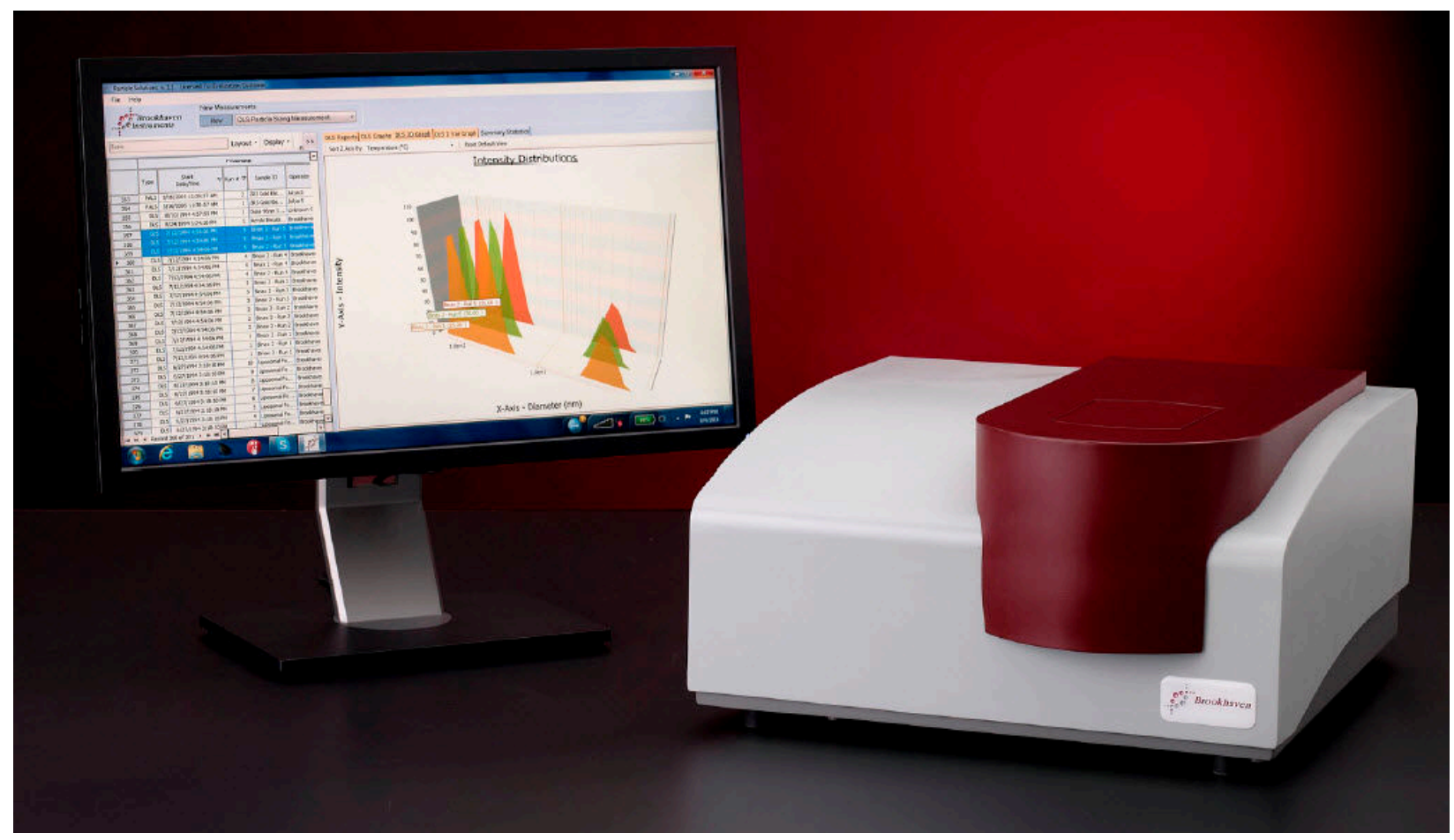

Figure 3-4. Brookhaven Instruments 90-Plus Particle Size Analyzer

(brookhaveninstruments.com)

DLS is one of the most widely applied techniques for colloidal system study, and it provides fast, accurate, and reliable results (Bryant \& Thomas 1995). When a beam of monochromatic laser light hit particles in solution, the light scatters in all directions — an effect also known as Rayleigh scattering. As the scattering intensity fluctuates over time, Brownian 
motion of the particle is measured; assuming particles moving independently from each another, the hydrodynamic diameter $\mathrm{d}$ can be deduced from the Stokes-Einstein equation:

$$
D=\frac{k_{B} T}{3 \pi \eta d}
$$

Where,

$\mathrm{D}=$ transitional diffusion coefficient;

$\mathrm{k}_{\mathrm{B}}=$ Boltzmann's constant $\left(1.38 \times 10^{-23} \mathrm{~m}^{2} \mathrm{~kg} \mathrm{~s}^{-2} \mathrm{k}^{-1}\right)$;

$\mathrm{T}=$ temperature $(\mathrm{K})$;

$\eta=$ solution viscosity $(\mathrm{Pa} \mathrm{s})$;

$\mathrm{d}=$ hydrodynamic diameter.

Because particle sizes are determined by the observation of particle motion, the diameter obtained by DLS method is "the diameter of a sphere that has the same translational diffusion coefficient as the particle" (Malvern Instruments, 2012). Specifically, the translational diffusion coefficient depends on the core size of the particle, surface structures and concentration and type of ions in the dispersion system.

Two models are available for the representation of PSD: the Lognormal Size Distribution (LSD), and the Multimodal Size Distribution (MSD). The LSD model provides a simplified approach that assumes a single log normal distribution with only one unified size distribution peak generated. The MSD model, however, uses a Non-Negatively constrained Least Squares (NNLS) algorithm to fit the data, an approach that offers more information about the presence of different sizes of particles and the relative intensity of different-size groups (Brookhaven Instruments Inc., 1995; Beliciu \& Moraru, 2009). Figure 3-5 provides a simple comparison of LSD and MSD. 

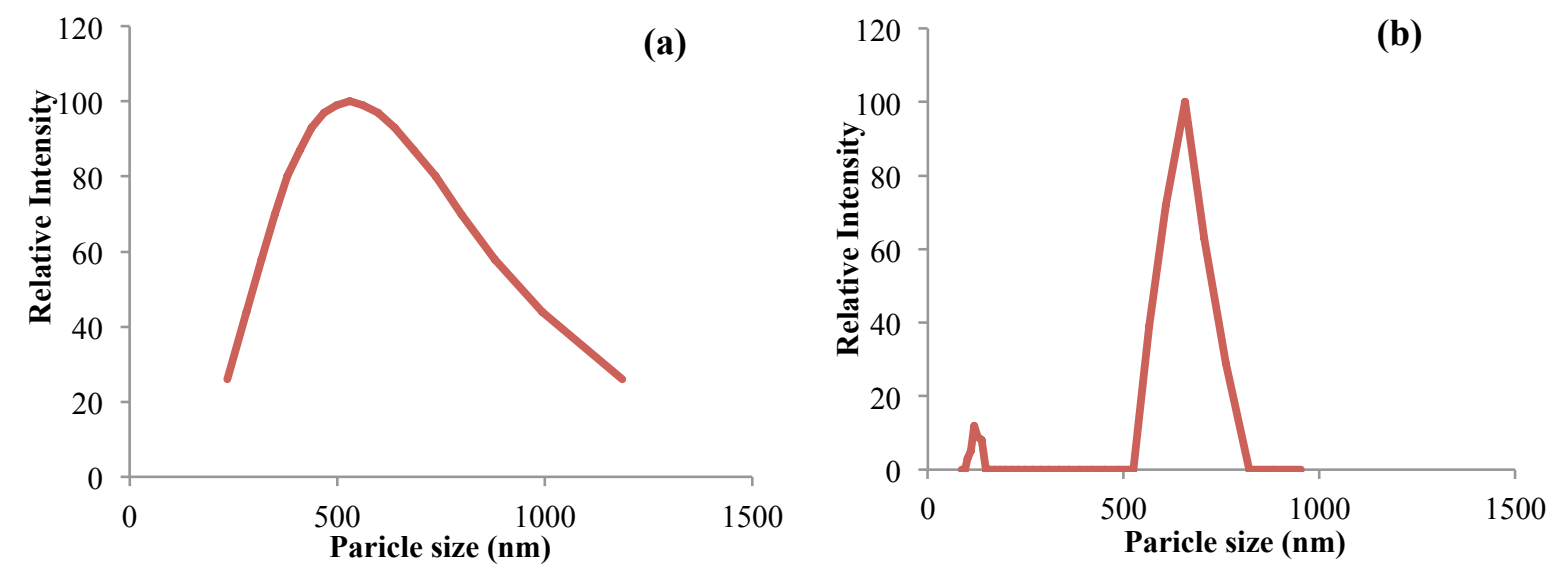

Figure 3-5. Different representation models for particle size distribution of study sample CC731-Day 1: (a) Lognormal Size Distribution (LSD) and (b) Multimodal Size Distribution (MSD)

The MSD model is more accurate in representing different size groups and serves as a more appropriate approach within the context of suspended solids characterization in produced water. Accordingly, the MSD algorithm was selected to represent particle size distribution; in this study, the results of three runs were averaged to calculate the apparent hydrodynamic diameter of particles.

\subsection{X-ray Photoelectron Spectroscopy}

X-ray photoelectron spectroscopy (XPS) is a surface-sensitive, semi-quantitative technique that measures the elemental composition of a sample - typically a powder sample. An empirical formula and chemical state can be deduced from the binding energy shift and relative intensity through high-resolution scans of selected elements.

A typical XPS system, shown in Figure 3-6, consists of three parts: a monochromatic Xray source, electron energy analyzer, and a detector (Haasch, 2014). The X-ray source generates a beam of incident photons with energy hv and, when an atom absorbs an X-ray photon, a 
photoelectron is emitted with a kinetic energy of $\mathrm{E}_{\mathrm{K}}$. The detector then measures the emitted kinetic energy $E_{K}$. The unique binding energy specific to each element can be calculated by:

$$
E_{B}=h v-E_{K}-W
$$

Where hv is the photon energy (for a $\mathrm{Al} \mathrm{K} \alpha \mathrm{X}$-ray source, $\mathrm{hv}=1486.6 \mathrm{eV}$ ); $\mathrm{E}_{\mathrm{K}}$ is the kinetic energy of the electron; and $\mathrm{W}$ is the spectrometer work function. These three parameters are either known or measurable; these values allow the binding energy to be derived easily

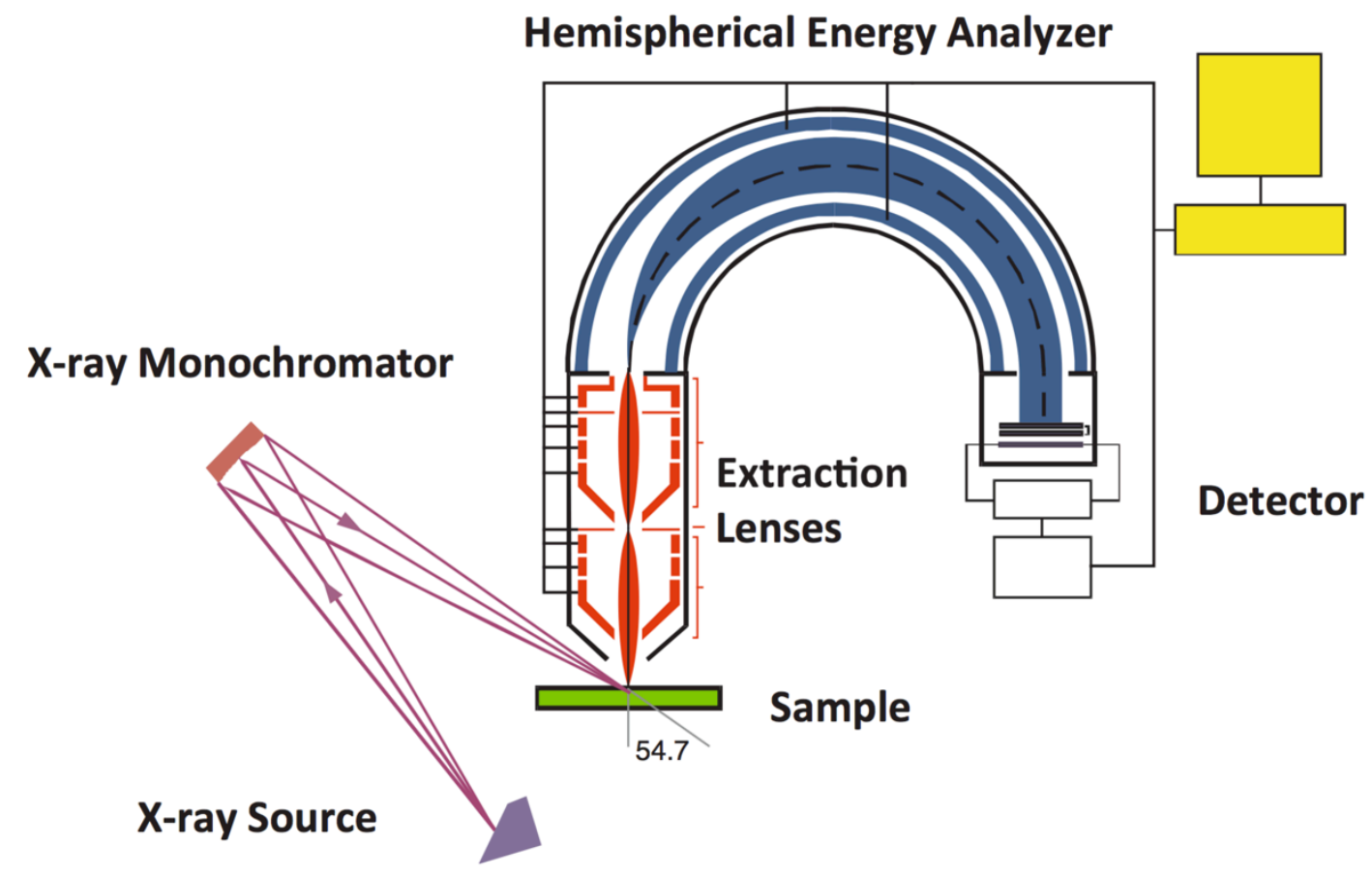

Figure 3-6. Schematic of a typical, modern high resolution X-ray photoelectron spectrometer (Haasch, 2014)

The surface chemistry of isolated suspended solids samples was analyzed by a PEI-5800 XPS-Auger spectrometer (Physical Electron, MN) at the Central Instrument Facility (CIF), Colorado State University (Figure 3-7). The PEI-5800 system was equipped with a monochromatic $\mathrm{Al} \mathrm{K \alpha} \mathrm{X}$-ray source $(\mathrm{hv}=1486.6 \mathrm{eV})$ and operated at an ultra-high vacuum pressure greater than $10^{-8}$ Torr. 


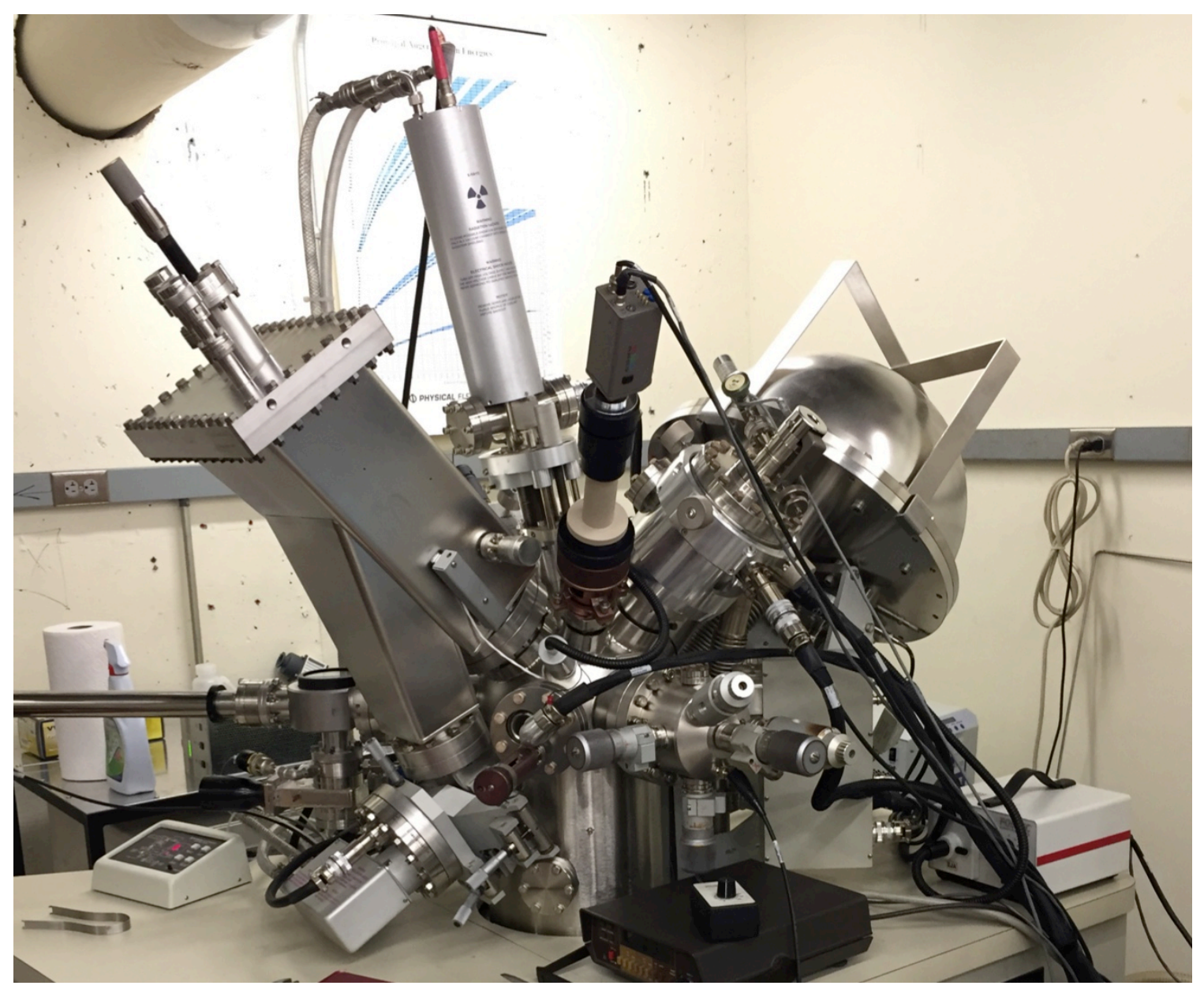

Figure 3-7. PEI-5800 XPS-Auger spectrometer system

Measurements were taken at a photoelectron takeoff angle of $45^{\circ}$ relative to the surface plane. Ten surveys were scanned over the range of $0-1100 \mathrm{eV}$, at a resolution of $1 \mathrm{eV}$. Highresolution spectra of selected element were acquired at a pass energy of $23.5 \mathrm{eV}$ and a step- size of $0.1 \mathrm{eV}$.

Binding energies were referenced to the $\mathrm{C} 1$ s line of adventitious hydrocarbon at 284.8 eV. XPS peak 4.1 software was used to fit the core level XPS spectra: line shape was fitted with a Lorentzian-Gaussian ratio of less than 20 percent, and the full width at half-maximum 
(FWHM) was referenced with literature values or set to lower than 2 for an automatic approximation. 


\section{Journal Article}

Summary

Water management is a central issue in oil and gas development. Hydraulic fracturing applied in unconventional tight oil and gas development requires large amounts of water, and the disposal of the waste stream returning to the surface has raised significant public health and environmental concerns. The wastewater that results after production contains high levels of organic and inorganic matters, and the beneficial reuse of produced water requires some level of treatment to remove emulsified oil and grease, suspended solids, and multivalent ions that could cause potential scale or clogging problems in future application. It is critically important to identify the quantity and makeup of solids in produced water, so that optimized reuse or treatment approach can be achieved.

This study targeted the qualitative and quantitative characterization of solids in produced water from oil and gas operations, with the purpose of identifying the difference in solids from wells fractured with fresh water and those fractured with recycled water. Samples were collected from five wells at the Crow Creek and Chandler State pads in the Wattenberg field of Northern Colorado. Gravimetric analyses of dissolved and suspended solids were performed and particle size distributions were measured. Suspended solids also were isolated and characterized with Xray photoelectron spectroscopy (XPS).

Gravimetric analyses showed that total dissolved solids (TDS) averaged about 24000 mg/L and $17000 \mathrm{mg} / \mathrm{L}$ for Crow Creek and Chandler State wells, respectively. Total suspended solids (TSS) concentrations were much lower, measuring 550 and $260 \mathrm{mg} / \mathrm{L}$ for two pads, respectively. About 9 to 25 percent of TDS was volatile, and volatile portion of TSS were measure from 88 to 99 percent. Particle sizes stabilized at about $400 \mathrm{~nm}$ and $900 \mathrm{~nm}$ for wells 
on the Crow Creek and Chandler State pads, respectively. At the Crow Creek pad, particle sizes were smaller and more uniform in produced water samples collected during the first week of production from the well fractured with recycled water, suggesting that the recycled water was more compatible with shale formation and that wells fractured with recycled water tend to clean out faster. XPS tests for isolated suspended solids showed the presence of major elements such as oxygen, carbon, and silicon, along with minor element such as calcium, magnesium, zirconium, iron, and others. Core-level scanning confirmed that the isolated suspended solids were composed mainly of carbonate-based minerals and metal oxides; several iron compounds with different valences also were found in sample.

Key words: Produced water, Wattenberg Field, solid characterization, particle size, XPS

\subsection{Introduction}

Oil and gas are main energy sources worldwide. Recent development of technology involving horizontal drilling and hydraulic fracturing offers tremendous potential in unconventional oil and gas production. U.S. production of tight oil has increased dramatically from less than one million barrels per day (MMbbl/d) in 2010 to more than three $\mathrm{MMbbl} / \mathrm{d}$ in 2013 (EIA, 2014). Hydraulic fracturing of tight shale formations requires a large amount of water, compared to conventional oil and gas production. Goodwin et al. (2013) estimated that each vertical and horizontal well in the Wattenberg field of Northern Colorado uses an average of 0.4 and 2.9 million gallons of water, respectively. With oil-rich fields often located in waterscarce areas, the water demand of oil and gas production could add to the already-intense demand for water for municipal and agricultural purposes or even contribute to water shortages during severe drought conditions. 
Large amounts of water are used to deliver the fracturing package under extremely high pressure; this effort opens up fractures within the target formation, and a large portion of coproduced water eventually flows back the with oil and gas product. The transport, treatment, and reuse of this produced water, after it is separated from the crude oil, have become crucial waste management and environment issues. The most common means of disposing wastewater from oil and gas production in the United States is through deep well injection - a practice that costs an average of 1 to 4 U.S. dollars per barrel (Clark and Veil, 2009). However, an increasing number of oil and gas companies are taking advantage of using produced water as a component of fracturing fluid for new wells (Huang et al., 2006); this practice could significantly minimize the demand for fresh water and the transportation and handling costs for deep well injection.

With multiple studies focused on produced water qualities and characterization (Benko and Drewes, 2008; Alley et al., 2011; Barbot et al., 2013), the suspended solids characteristics of produced water and its dispersed system has hardly been investigated. The understanding of solids properties and chemical composition will help guide the selection of the treatment technique that will improve wastewater treatment effectiveness and allow beneficial wastewater reuse. In this study, dissolved and suspended solids of produced water were characterized with gravimetric and particle sizing analyses; suspended solids were captured and surface chemistry was tested through X-ray photoelectron spectroscopy (XPS). The effect of using fresh surface water, compared to recycled produced water, on the resulting produced water qualities was also studied.

\section{Research objectives:}


1. To characterize solids, both qualitatively and quantitatively, in produced water flowing back from unconventional wells in oil and gas operations.

2. To compare the difference between solids from wells fractured with fresh water and recycled water.

3. To develop solids isolation and preparation protocols and characterize the solids with X-ray photoelectron spectroscopy (XPS).

\subsection{Methods}

\subsubsection{Sampling Methods}

Two Noble Energy Inc. well pads were studied: Crow Creek and Chandler State, both located in the Wattenberg field of Northern Colorado as shown in Figure 4-1. Five wells, described in Table 4-1, were selected from these two pads, and water samples were collected from each well after flowback started. Wells from the same pad were constructed at the same time and parallel to each other.

Table 4-1. Five wells selected for study

\begin{tabular}{ccccccc}
\hline Well Name & API \# & $\begin{array}{c}\text { True } \\
\text { vertical } \\
\text { depth } \\
\text { (ft) }\end{array}$ & Formation & $\begin{array}{c}\text { \# of } \\
\text { Stages }\end{array}$ & $\begin{array}{c}\text { Frac } \\
\text { Fluid } \\
\text { Type }\end{array}$ & $\begin{array}{c}\text { Fracturing source } \\
\text { water }\end{array}$ \\
\hline $\begin{array}{c}\text { Crow Creek } \\
\text { State AC36- } \\
\text { 73HN }\end{array}$ & $05-123-37423$ & 6,685 & Niobrara & 20 & PermStim & $1: 7$ recycle/fresh \\
$\begin{array}{c}\text { Crow Creek } \\
\text { State AC36- } \\
\text { 76-1HN }\end{array}$ & $05-123-37420$ & 6,742 & Niobrara & 20 & PermStim & $100 \%$ fresh \\
$\begin{array}{c}\text { Chandler State } \\
\text { D15-72-1HN }\end{array}$ & $05-123-38322$ & 6,750 & Codell & 23 & SilverStim & $100 \%$ fresh \\
$\begin{array}{c}\text { Chandler State } \\
\text { D15-73-1HN }\end{array}$ & $05-123-38323$ & 6,750 & Codell & 23 & SilverStim & $1: 7$ recycle:fresh \\
$\begin{array}{c}\text { Chandler State } \\
\text { D15-74-1HN }\end{array}$ & $05-123-38321$ & 6,750 & Codell & 23 & SilverStim & $1: 5$ recycle:fresh \\
\hline
\end{tabular}




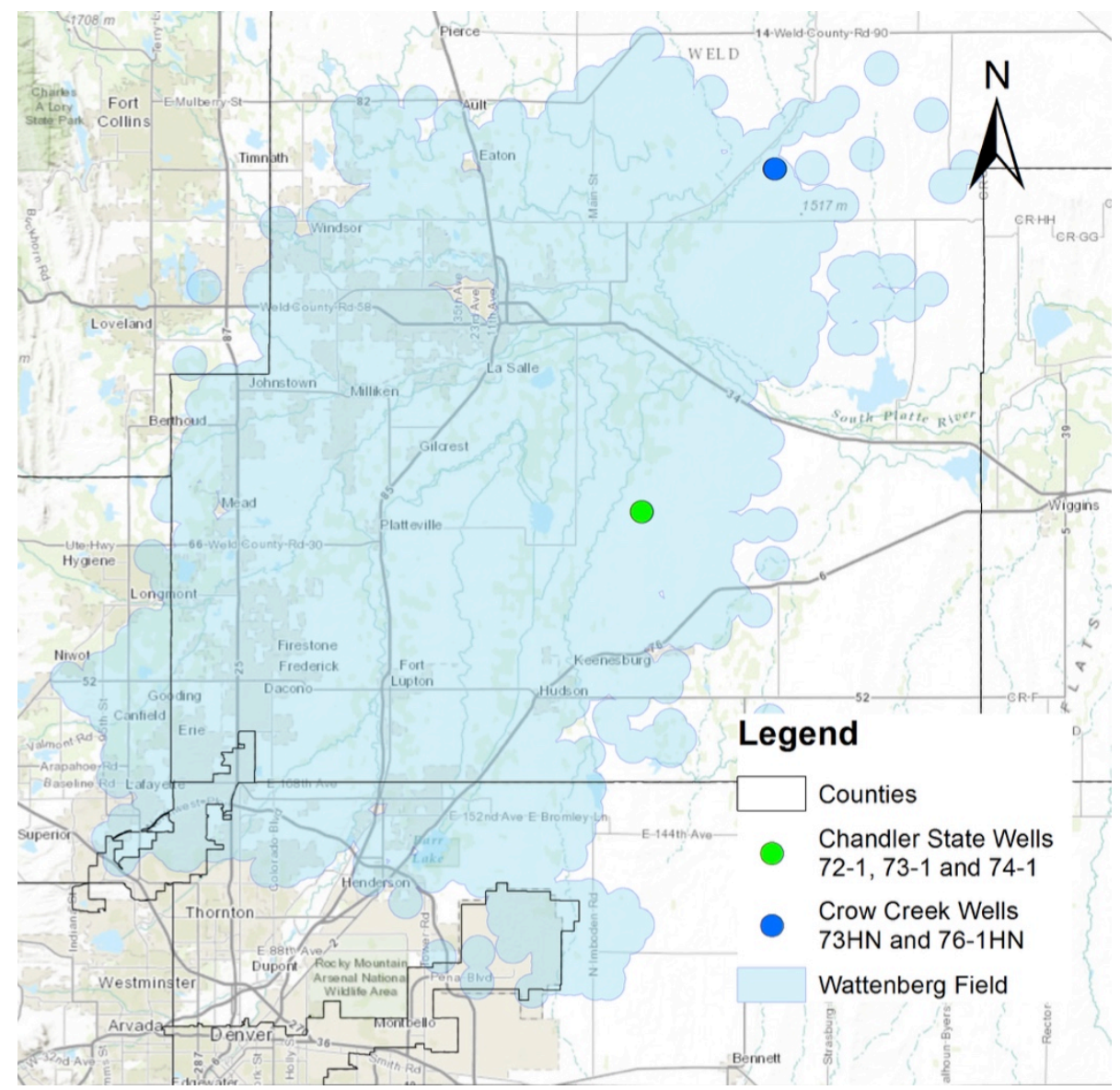

Figure 4-1. Location of wells within the Chandler State and Crow Creek pads

4.2.2 Gravimetric analyses and produced water quality

Gravimetric analyses of solids were conducted according to Standard Method 2540 (APHA, 1995). Samples for total solids (TS), total dissolved solids (TDS), and total suspended solids (TSS) determination were dried at $105^{\circ} \mathrm{C}$; samples collected for total volatile solids (TVS), volatile dissolved solids (VDS), and volatile suspended solids (VSS) determinations were muffled at $550{ }^{\circ} \mathrm{C}$. Whatman $934-\mathrm{AH}$ glass microfiber filters $(1.5-\mu \mathrm{m}$ equivalent pore size $)$ were used to filter samples. Metal and ion concentrations also were determined for reference. Ion 
concentration data were collected from Nalco Champion (Ecolab USA Inc.) and eAnalytics Laboratory (Loveland, CO) for Crow Creek wells and Chandler State wells, respectively.

\subsubsection{Particle Sizing}

Particle size and particle size distribution (PSD) are the key properties describing colloidal and dispersed systems. In this study, a dynamic light scattering (DLS) method was applied to size particles, using a 90-Plus Particle Size Analyzer (Brookhaven Instruments, NY) at a fixed, scattering angle of $90^{\circ}$ and temperature of $25^{\circ} \mathrm{C}$.

A multimodal size distribution (MSD) algorithm was used to represent particle size distribution (PSD); the results of three runs were averaged to calculate the apparent hydrodynamic diameter of particles.

\subsubsection{X-ray Photoelectron Spectroscopy (XPS)}

The surface chemistry of isolated suspended solids samples was analyzed by a PEI-5800 XPS-Auger spectrometer (Physical Electron, MN) at the Central Instrument Facility (CIF), Colorado State University. The PEI-5800 system was equipped with a monochromatic Al Ka X-

ray source $(\mathrm{h} v=1486.6 \mathrm{eV})$, and operated at an ultra-high vacuum pressure greater than $10^{-8}$ Torr. Measurements were taken at a photoelectron takeoff angle of $45^{\circ}$ relative to the surface plane. Ten surveys scanned over the range of $0-1100 \mathrm{eV}$, at a resolution of $1 \mathrm{eV}$, were averaged. Highresolution spectra of selected element were acquired at a pass energy of $23.5 \mathrm{eV}$ and a step- size of $0.1 \mathrm{eV}$. Binding energies were referenced to the $\mathrm{C} 1 \mathrm{~s}$ line of adventitious hydrocarbon at 284.8 eV. XPSPEAK 4.1 software was used to fit the core level XPS spectra.

To better capture suspended solids in produced water for XPS elemental testing, a solids separation protocol was developed. The following preparation steps were applied: 1) $200 \mathrm{~mL}$ of water sample was dried at $105{ }^{\circ} \mathrm{C}$ and then burned at $550{ }^{\circ} \mathrm{C}$ in a muffle furnace; residuals were 
ground into a fine powder; 2) the fine powder was dissolved into $200 \mathrm{~mL}$ of deionized water with a magnetic stirrer; 3) the mixed solution was filtered through a $0.2-\mu \mathrm{m}$ silver filter (Sterlitech Corp. WA) under vacuum; 4) filter was then rinsed with $200 \mathrm{~mL}$ deionized water to wash off dissolved salts; 5) the filter was furnaced again at $550{ }^{\circ} \mathrm{C}$ and the sample was tested by XPS within one hour to prevent possible organic carbon contamination through air exposure.

\subsection{Results and Discussion}

\subsubsection{Produced Water Quality and Solids Distribution}

Table 2 summarizes the water quality of Crow Creek and Chandler State wells. While metal ions such as calcium, magnesium, iron, strontium, and zirconium were present, sodium chloride was found to be the dominant salt in both well pads. Sample $\mathrm{pH}$ averaged approximately 7.5 , and sample buffer capacity was relatively high--suggesting that a significant amount of acid or base might be required for softening, if treatment was deemed necessary. Water quality was found to vary considerably from well to well, and organic and inorganic constituent concentrations of samples from Crow Creek wells were nearly all considerably higher than those of samples from Chandler State wells. Specifically, TOC and DOC levels of Crow Creek samples were twice as high as those measured in samples collected from the Chandler State wells. Average TDS measured in Crow Creek well samples was 40 percent higher than that found in Chandler State well samples. The sulfate concentration averaged 368 $\mathrm{mg} / \mathrm{L}$ and $29 \mathrm{mg} / \mathrm{L}$ in samples from Crow Creek wells and Chandler State wells, respectively. Because sulfate forces the precipitation of barium, barium was the only parameter found to be lower in the Crow Creek well samples. Overall, the characteristics of inorganic constituents in produced water are primarily inherited from the rock formations with which the water had 
contact (Benko and Drewes, 2008). Consequently, the difference in inorganic constituent-related water quality between the wells is due, in part, to the geologic variations within the Wattenberg field.

Table 4-2. Water Quality Summary for Crow Creek and Chandler State Wells

\begin{tabular}{|c|c|c|c|c|c|c|}
\hline Wells & \multicolumn{3}{|c|}{ Crow Creek wells 73 and 76-1 } & \multicolumn{3}{|c|}{$\begin{array}{c}\text { Chandler State wells } 72-1,73-1 \\
\text { and } 74-1\end{array}$} \\
\hline Number of samples & \multicolumn{3}{|c|}{$\begin{array}{l}60 \text { Samples collected from day 1- } \\
54\end{array}$} & \multicolumn{3}{|c|}{$\begin{array}{l}\text { 69 Samples collected from day 1- } \\
71\end{array}$} \\
\hline Parameters & Minimum & Maximum & Average & Minimum & Maximum & Average \\
\hline $\mathbf{p H}$ & 6.6 & 9.1 & 7.5 & 6.2 & 9.0 & 7.4 \\
\hline Cond. $\quad(\mathrm{mS} / \mathrm{cm})$ & 0.9 & 52.9 & 20.8 & 14.6 & 44.1 & 23.8 \\
\hline TOC $(\mathrm{mg} / \mathrm{L})$ & 362 & 12,170 & 4,320 & 80 & 4,845 & 2,038 \\
\hline DOC $(\mathrm{mg} / \mathrm{L})$ & 366 & 11,930 & 3,079 & 87 & 2,125 & 1,477 \\
\hline $\begin{array}{ll}\text { Alkalinity } & (\mathrm{mg} / \mathrm{L} \text { as } \\
\left.\mathrm{CaCO}_{3}\right)\end{array}$ & 234 & 2,264 & 1,301 & 432 & 1,488 & 975 \\
\hline TS $\quad(\mathbf{m g} / \mathbf{L})$ & 1,540 & 38,940 & 25,638 & 9,020 & 40,060 & 17,333 \\
\hline TDS $\quad(\mathrm{mg} / \mathrm{L})$ & 1,420 & 33,760 & 24,357 & 12,880 & 25,620 & 16,955 \\
\hline TSS $\quad(\mathrm{mg} / \mathrm{L})$ & 21 & 1,542 & 550 & 44 & 1,229 & 257 \\
\hline TVS $\quad(\mathrm{mg} / \mathrm{L})$ & 360 & 17,880 & 5,469 & 940 & 24,480 & 3,985 \\
\hline VDS $\quad(\mathrm{mg} / \mathrm{L})$ & 340 & 10,940 & 4,250 & 780 & 5,420 & 3,384 \\
\hline VSS $\quad(\mathrm{mg} / \mathrm{L})$ & 4 & 1,524 & 516 & 23 & 1,208 & 239 \\
\hline Al $\quad(m g / L)$ & 0.1 & 16.0 & 5.4 & 0.1 & 1.4 & 0.6 \\
\hline B $(\mathrm{mg} / \mathrm{L})$ & & & & 5.0 & 20.4 & 15.3 \\
\hline $\mathrm{Ba} \quad(\mathrm{mg} / \mathrm{L})$ & 0.1 & 5.6 & 2.1 & 1.5 & 15.5 & 6.4 \\
\hline $\mathrm{Br} \quad(\mathrm{mg} / \mathrm{L})$ & & & & 25 & 51 & 35 \\
\hline $\mathrm{Ca} \quad(\mathrm{mg} / \mathrm{L})$ & 43 & 435 & 269 & 54 & 186 & 104 \\
\hline $\mathrm{Cu} \quad(\mathrm{mg} / \mathrm{L})$ & 0.0 & 0.4 & 0.1 & & & \\
\hline $\mathrm{Fe} \quad(\mathrm{mg} / \mathrm{L})$ & 4.2 & 171.1 & 44.0 & 0.5 & 60.4 & 29.8 \\
\hline $\mathrm{K} \quad(\mathrm{mg} / \mathrm{L})$ & & & & 40 & 3,399 & 120 \\
\hline $\operatorname{Mg}(\mathrm{mg} / \mathrm{L})$ & 21.3 & 57.7 & 37.1 & 7.5 & 25.1 & 14.9 \\
\hline $\mathrm{Na} \quad(\mathrm{mg} / \mathrm{L})$ & 107 & 10,199 & 5,553 & 2,339 & 7,156 & 4,384 \\
\hline $\mathrm{Si} \quad(\mathrm{mg} / \mathrm{L})$ & & & & 4 & 60 & 45 \\
\hline $\mathrm{Sr} \quad(\mathrm{mg} / \mathrm{L})$ & 0.1 & 60.4 & 31.9 & 7.7 & 31.6 & 16.5 \\
\hline $\mathrm{Zn} \quad(\mathrm{mg} / \mathrm{L})$ & 0.0 & 0.8 & 0.1 & 0.2 & 6.7 & 0.9 \\
\hline Cl $\quad(\mathrm{mg} / \mathrm{L})$ & 163 & 15,712 & 8,458 & 4,980 & 10,800 & 7,072 \\
\hline $\mathrm{NH}_{4} \quad(\mathrm{mg} / \mathrm{L})$ & & & & 10 & 130 & 21 \\
\hline $\mathrm{HCO}_{3} \quad(\mathrm{mg} / \mathrm{L})$ & 63 & 3,660 & 1,190 & 512 & 1,476 & 955 \\
\hline $\mathrm{SO}_{4} \quad(\mathrm{mg} / \mathrm{L})$ & 316 & 446 & 368 & 1 & 268 & 29 \\
\hline
\end{tabular}


Figure 4-2 details the volatile portion of each solids category. About 13 to 46 percent of TS, and 9 to 25 percent of TDS, were volatile, indicating that a large amount of organic compounds were present in the produced water. TSS also was found to be highly volatile, ranging from 88 to 99 percent. During TSS determination, a large amount of emulsified oil was caught on the filter when isolating suspended solids--likely the reason why such a high volatile percentage of suspended solids was recorded. Given the organic-rich nature of produced water, a new suspended solids isolation protocol was established for better performance in XPS testing, as discussed in Methods Section 4.2.4.

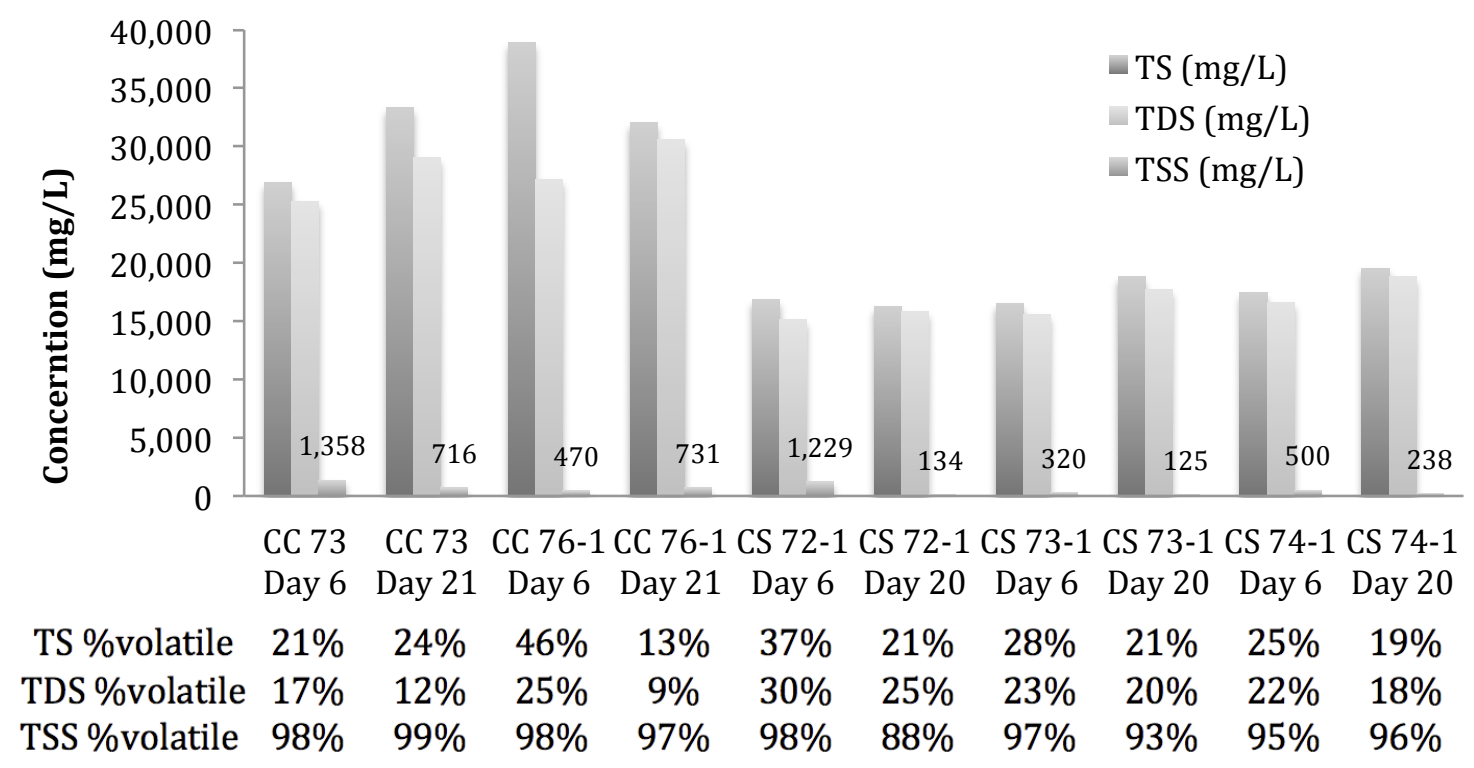

Figure 4-2. Solids distribution for Chandler State wells on Day 6 and Day 20 and Crow Creek wells on Day 6 and Day 21. The lower table summarizes the volatile portion of solids in each category.

Consistent TDS values were found within the same pad, suggesting that fracturing wells with some portion of recycled water might not necessarily lower the produced water quality with respect to inorganic constituents. As discussed above, effluent TDS concentrations are most 
likely influenced by the brine and salt layer of the shale formation itself, and not by the water quality of fracturing source water.

\subsubsection{Particle Size Distribution}

Particle size and particle size distribution (PSD) are the key properties of colloidal and dispersed systems. Solids in produced water represent a wide range of materials, including formation solids, corrosion and scale products, bacteria, waxes, and asphaltenes (Fakhrul et al., 2009). Effective particle diameter, illustrated in Figure 4-3, represents an average size of the particles in the sample. Higher particle sizes were measured in the preflow and Day 1 samples, but that trend flattens out soon after production. Large particles observed during the earlyproduction period might have originated from clay content in the shale formation and/or the fracturing package (crosslinking gel, sand proppant, etc.). PSD profiles presented in Figure 4-4 show that early flowback samples contained a large variety of solids with particles ranging from 100 to $10,000 \mathrm{~nm}$. As the high pressure of hydraulic fracturing dropped after production, fractures tended to close up enough to block the passage of larger particles. Once particle size stabilized, measurements showed the Chandler State wells had larger particle sizes than the Crow Creek wells. Particle sizes in Crow Creek pad samples stabilized at about 100 to $200 \mathrm{~nm}$; most particles measured in Chandler State pad samples were greater than $400 \mathrm{~nm}$ in the first 20 days. However, during the first week of production, the Crow Creek well fractured with fresh water-well CC-76-1--was found to have larger particle sizes than the well fractured with recycled water (CC-73). 


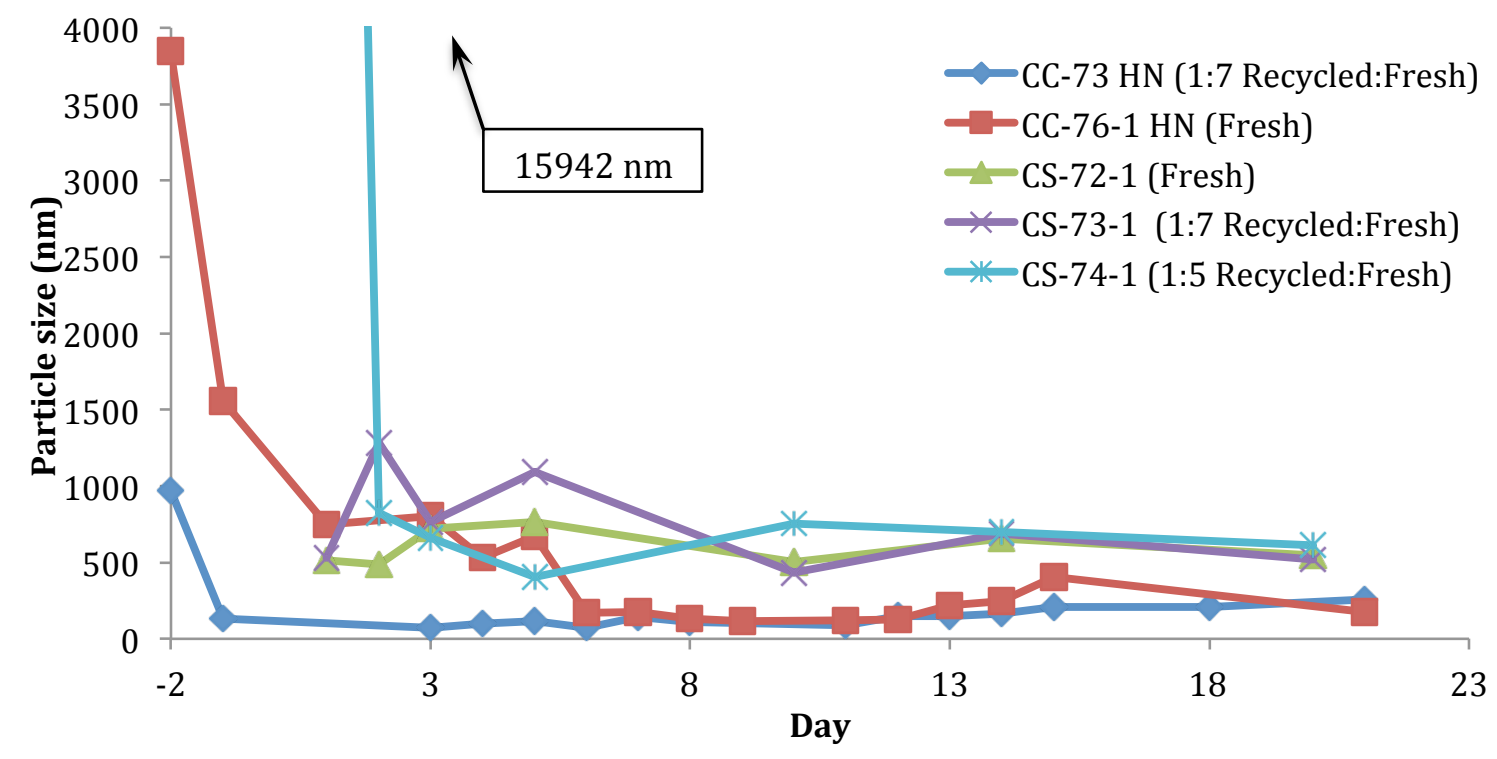

Figure 4-3. A summary of effective particle sizes for Crow Creek and Chandler State wells (Day -2 and Day -1 day represent the pre-flow period before production, and Day 1 refers to the production day.)

Figure 4-4 illustrates the different PSD patterns between well CC-73 and CC-76-1: well 76-1 particles showed a broader peak width and multiple peaks of size distribution, compared to well 73 that showed a smaller particle size and a uniform mono distribution peak after production. In general, CC-73 had smaller particle sizes and tended to clean out much faster than well CC-76-1. One theory is that recycled water has higher salinity and is more compatible with shale formation; therefore, the mineral solubility equilibrium and chemical equilibrium can be established much faster. Yet, similar effects were not found in early Chandler State well samples, other than the extremely high particle size recorded in CS-74-1 Day 1 sample, in which tiny black particles could be seen floating. Later XPS testing suggested these particles could be iron oxides. 

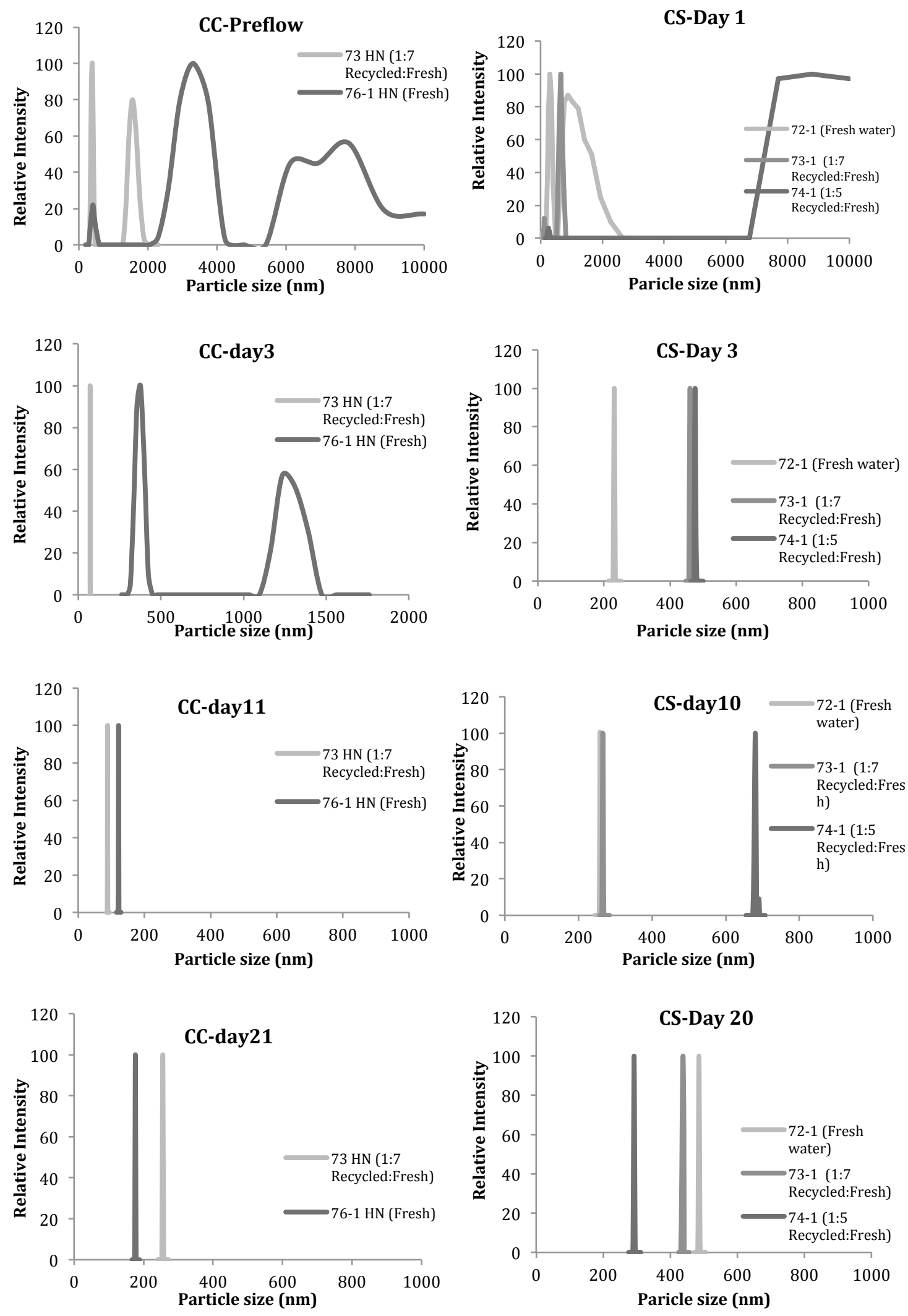

Figure 4-4. Particle size distribution (PSD) for Crow Creek and Chandler State wells 


\subsubsection{X-ray Photoelectron Spectroscopy (XPS)}

Analyzing the XPS spectra of peaks at different levels of binding energy allowed all elements present in the solid samples to be identified; the full list of elements and relative atomic percentages is presented in Table 4-3. For oxygen, carbon, silicon and magnesium, detailed temporal trends are provided in Figure 5.

Table 4-3.Atomic Percentage of All Elements for Chandler State Wells 72-1 HN, 73-1 HN and 74-1 HN, from Day 1 to Day 20 of production

\begin{tabular}{|c|c|c|c|c|c|c|c|c|c|c|c|c|c|c|c|}
\hline \multirow{2}{*}{$\begin{array}{c}\text { Well No. } \\
\text { Day }\end{array}$} & \multicolumn{5}{|c|}{ CS $72-1 \mathrm{HN}$} & \multicolumn{5}{|c|}{ CS 73-1 HN } & \multicolumn{5}{|c|}{ CS 74-1 HN } \\
\hline & 1 & 2 & 6 & 10 & 20 & 1 & 2 & 6 & 10 & 20 & 1 & 2 & 6 & 10 & 20 \\
\hline Oxygen & 58.3 & 53.4 & 60.4 & 49.7 & 52.2 & 58.5 & 43.2 & 56.8 & 58.1 & 56.2 & 63.9 & 44.5 & 55.3 & 56.8 & 62.5 \\
\hline Carbon & 6.6 & 13.2 & 6.2 & 16.2 & 10.4 & 6.7 & 13.1 & 5.8 & 6.2 & 4.1 & 4.1 & 11.8 & 8.6 & 5 & 5.9 \\
\hline Silicon & 12.1 & 10.9 & 14.6 & 9.3 & 15 & 12.5 & 9.3 & 14.6 & 9 & 11.2 & 6.5 & 7.7 & 14.5 & 13.4 & 11.9 \\
\hline Calcium & 3.6 & & 1.4 & 2.8 & 5.1 & & & 2.6 & 4 & 2.9 & 7.1 & 2.8 & 3.7 & 2.8 & 1.8 \\
\hline Magnesium & 1.5 & 3.8 & 1.3 & 3.1 & 3.1 & 3.6 & 18.2 & 4.3 & 4.5 & 5.7 & 10.1 & 15.5 & 5 & 5.2 & 5.6 \\
\hline Zirconium & 1.7 & 2.7 & 1.3 & 0.7 & & 1.8 & 2.3 & 1.2 & 0.9 & 1 & & 2.3 & 0.8 & 1 & 1 \\
\hline Iron & 2.5 & 1.8 & 1.6 & 1.5 & 4.1 & 2.3 & 1.9 & 1.7 & 2.3 & 2.9 & 2.9 & 1.2 & & 1.6 & 3.5 \\
\hline Iodine & & 0.6 & & 3.9 & 2.1 & & 2.4 & 1.5 & 0.5 & 4.6 & & 1.8 & 0.6 & 2 & \\
\hline Sodium & 12.8 & 11.9 & 12.2 & 7.5 & 5.0 & 14.6 & 7.5 & 9.1 & 12.7 & 7.1 & 0.9 & 8.4 & 8.4 & 10 & 5.6 \\
\hline Chlorine & 1 & 0.9 & 0.4 & 0.9 & & & 0.6 & 1 & 1.3 & 1.1 & & 0.9 & 1.1 & 1 & 1.1 \\
\hline Nitrogen & & & 0.6 & 2.1 & & & & & & & & 1.6 & 1.3 & & \\
\hline Barium & & & & & & & & & & 0.1 & & 0.2 & 0.2 & & 0.1 \\
\hline Silver & & 0.7 & & 2.2 & 3 & & 1.5 & 1.4 & & 3.1 & & 1.4 & 0.5 & 1.2 & \\
\hline Sulfur & & & & & & & & & & & 2.7 & & & & \\
\hline Strontium & & & & & & & & & 0.5 & & & & & & \\
\hline Phosphorus & & & & & & & & & & & 1.8 & & & & \\
\hline
\end{tabular}

The data in Table 4-3 show that the most abundant element was oxygen, with an atomic percentage of 40 to 60 percent, followed by carbon and silicon. Because solid samples were burned at $550{ }^{\circ} \mathrm{C}$, as described in the preparation procedures detailed in the Methods section of this paper, only inorganic carbon was expected to remain in the residuals. It can be deduced that major chemical components were calcium/magnesium, carbonate mineral, and quartz/clay. 
Figure 4-5 shows all three wells followed similar temporal trends in atomic percentage of oxygen and silicon. Magnesium spiked at Day 2 in wells CS-73-1 and CS-74-1, fractured with recycled water, and their atomic percentages were continuously higher than those of well CS-72-1 fractured with fresh-source water. Iron presence was constant at about 2 to- 3 percent of atomic percentage; divalent ions such as barium and strontium were detected only sporadically. The relative abundance of zirconium (Zr) peaked at Day 2 in all three wells. Since Zicronium is generally considered insoluble in crustal fluids and only trace amounts of Zr-bearing mineral are found in shale formations (Werne et al., 2002; Odoma et al., 2015), Zr detected in produced water more likely originates from the cross-linker in the fracturing package. The zirconate-based cross-linker can link polymer molecules together; therefore, it increases the viscosity needed to open up fractures and deliver proppants into the target pay zone. As polymer gel is broken down, $\mathrm{Zr}$ is expected to be released and gradually cleaned out from the well bore. Temporal trend of $\mathrm{Zr}$ showed this break-down/clean-out process occurred quickly: the relative abundance of Zr decreased after Day 2 for all three wells. Silver spectra were identified occasionally because silver filters were used in this study; the use of silver filters was meant to eliminate interference of silicon spectra that might occur when using fiberglass filters. 

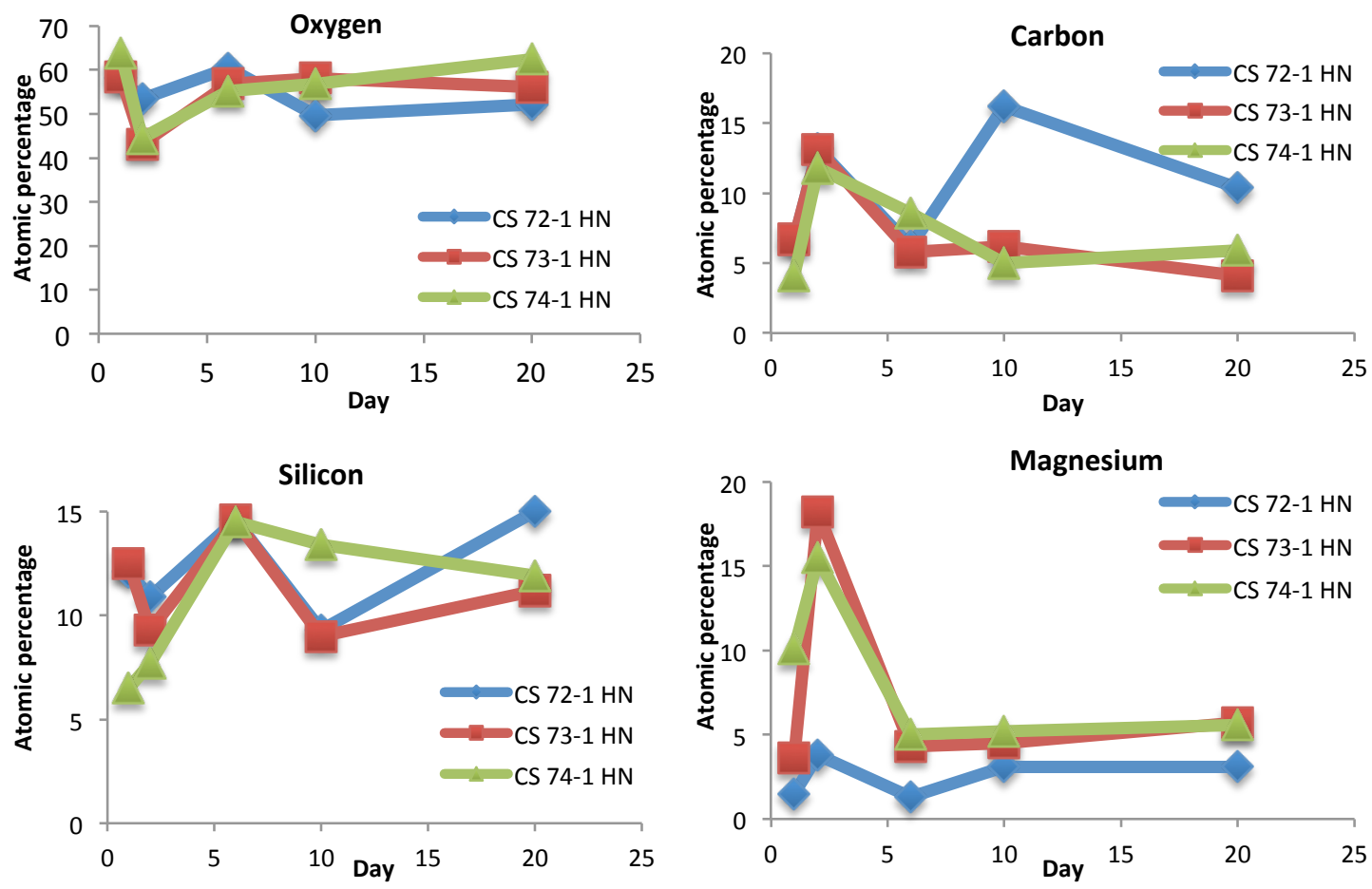

Figure 4-5. Temporal trending of oxygen, carbon, silicon and magnesium in samples from Chandler State wells 72-1 HN, 73-1 HN and 74-1 HN, from Day 1 to Day 20 of production.

Figure 4-6 presents XPS core-level spectra on selected elements. Core-level XPS of carbon and oxygen confirm that most of the suspended solids were composed of carbonate-based minerals and metal oxides. Multivalent iron species were identified, and Fe 2 $\mathrm{p}_{3 / 2}$ XPS spectra were fitted into three peaks at 710.2, 711.6, and $713.4 \mathrm{eV}$ for $\mathrm{Fe}_{3} \mathrm{O}_{4}, \mathrm{Fe}_{2} \mathrm{O}_{3}$ and $\mathrm{K}_{2} \mathrm{FeO}_{4}$, respectively (Deng et al., 2009). 


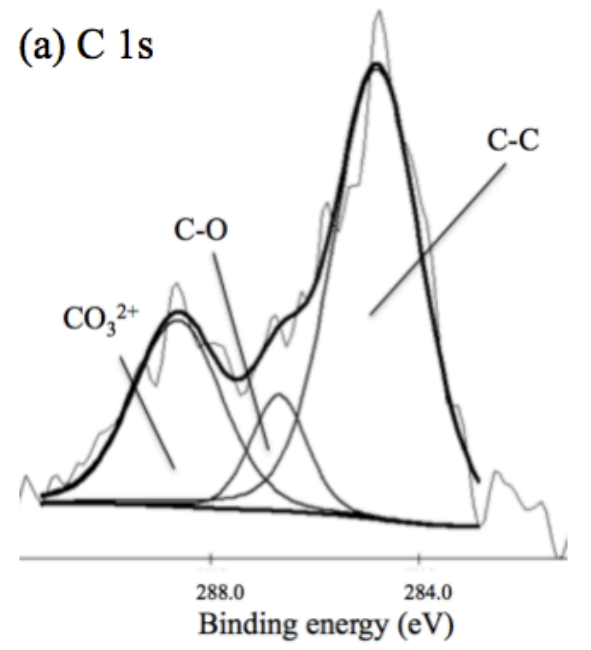

(c) $\mathrm{Fe} 2 \mathrm{p}_{3 / 2}$

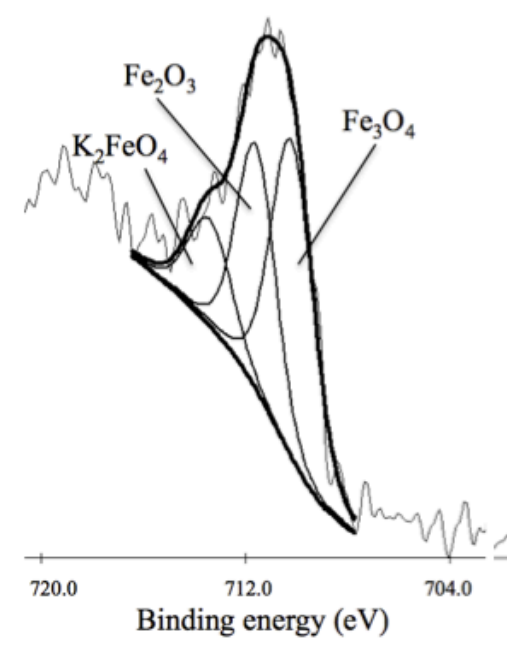

(d) Si $2 p$
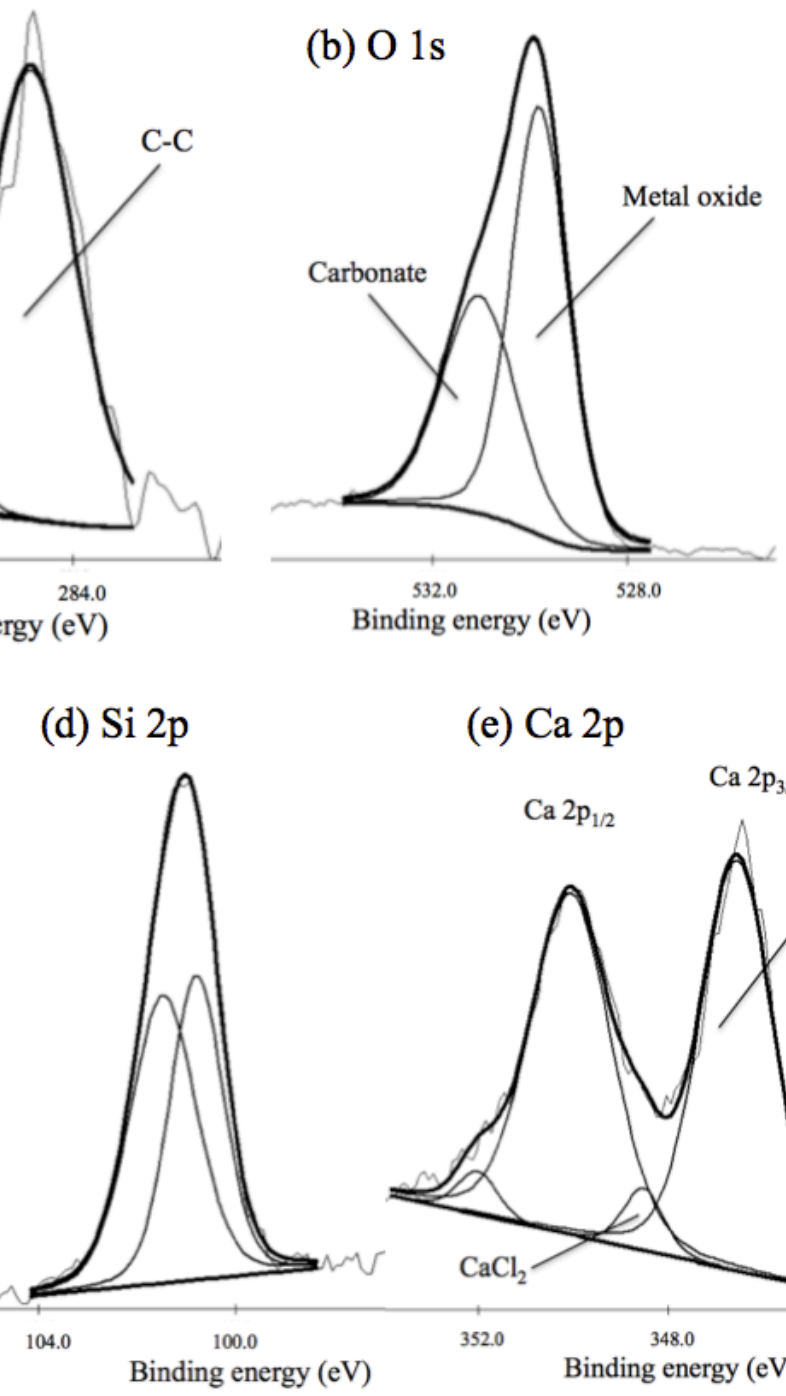

(e) $\mathrm{Ca} 2 \mathrm{p}$

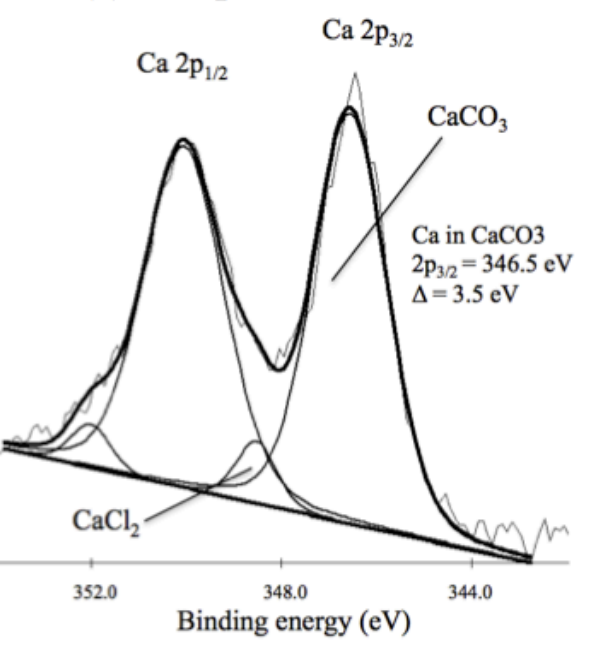

Figure 4-6. Core-level XPS spectra for isolated suspended solids from well CS 72-1 at Day 20:

$$
\text { (a) C 1s, (b) O 1s, (c) Fe 2p } 3 / 2 \text {, (d) Si 2p and (e) Ca 2p }
$$

As discussed previously, silicon is expected to be associated with silicate minerals. However, the high-resolution XPS spectra of silicon showed peaks at 100.8 and $101.5 \mathrm{eV}$ that did not match reference binding energy values for silica or silicate at around $103 \mathrm{eV}$. The 100.8 and $101.5 \mathrm{eV}$ peaks measured represent, instead, $\mathrm{SiC}$ and $\mathrm{Si}_{3} \mathrm{~N}_{4}$, respectively (Parrill \& Chung, 1991). Nevertheless, $\mathrm{SiC}$ and $\mathrm{Si}_{3} \mathrm{~N}_{4}$ are highly unlikely to be present in suspended solids in 
produced water. Silicon carbide and silicon nitride are rarely found in terrestrial mineral environments (Di Pierro et al., 2003), and natural occurrences are reported primarily in meteorite cases. A possible explanation for this lower binding energy shift could be that silica or silicate was bonded with metal ions. For example, Vempati et al. (1990) discovered that, when ferrihydrite co-precipitated with silica, the binding energy of silicon was shifted lower to 100.8 eV. Moreover, a study done by Gonzalez-Elipe et al. (1988) showed that, in the phyllosilicate minerals framework, substitution of $\mathrm{Al}$ or $\mathrm{Mg}$ for Si conferred net negative charge to the tetrahedral sheet, thus lowered the photoelectron binding energies of silicon and oxygen. While these are possible explanations, the complex nature of solids isolated from produced water make it difficult to determine its exact chemical composition.

Figure 4-6(e) shows the $\mathrm{Ca} 2 \mathrm{p}$ spectra. The main component at the binding energy of $346.5 \mathrm{eV}$ was attributed to $\mathrm{CaCO}_{3}$, while a smaller peak at $350 \mathrm{eV}$ can be assigned to $\mathrm{CaCl}_{2}$ (Demri\& Muster, 1995). The spin orbit splitting between $\mathrm{Ca} 2 \mathrm{p}_{3 / 2}$ and $\mathrm{Ca} 2 \mathrm{p}_{3 / 2}$ was found at $3.5 \mathrm{eV}$, which also matched literature values (Chastain \& King,1992; Demri\& Muster, 1995).

\subsection{Conclusions}

Suspended solids were successfully isolated and characterized by gravimetric analysis, particle sizing, and XPS. Gravimetric analyses showed that dissolved and suspended solids concentrations were similar for wells in the same pad. Major differences were found between the wells fractured with fresh water and recycled water with respect to particle size and PSD during the first week of production. The smaller and mono-distribution of particle size identified suggests that recycled water is more compatible with shale formation and that wells fractured with recycled water clean out faster. XPS tests confirmed the presence of major elements, 
including oxygen, carbon, and silicon, and some minor elements such as calcium, magnesium, zirconium, iron, and others. Core-level scanning confirmed that the isolated suspended solids were composed primarily of carbonate-based minerals and metal oxides; several iron compounds with different valences were also found in these samples. 


\section{Reference}

APHA (1995). Method 2540. Total, fixed, and volatile solids in solid and semi-solid samples. In: Standard Methods for the Examination of Water and Wastewater, 19th Ed. American Public Health Association, Washington, DC, USA. pp. 2-58.

Alley, B., Beebe, A., Rodgers, J., \& Castle, J. W. (2011). Chemical and physical characterization of produced waters from conventional and unconventional fossil fuel resources. Chemosphere, 85(1), 74-82.

Acharya, H. R., Henderson, C., Matis, H., Kommepalli, H., Moore, B., \& Wang, H. (2011). Cost effective recovery of low-TDS frac flowback water for re-use. US Department of Energy: Washington, DC.

Azema, N., Pouet, M. F., Berho, C., \& Thomas, O. (2002). Wastewater suspended solids study by optical methods. Colloids and Surfaces A: Physicochemical and Engineering Aspects, 204(1), 131-140.

Barbot, E., Vidic, N. S., Gregory, K. B., \& Vidic, R. D. (2013). Spatial and temporal correlation of water quality parameters of produced waters from Devonian-age shale following hydraulic fracturing. Environmental science \& technology, 47(6), 2562-2569.

Beliciu, C. M., \& Moraru, C. I. (2009). Effect of solvent and temperature on the size distribution of casein micelles measured by dynamic light scattering. Journal of dairy science, 92(5), 1829-1839.

Benko, K. L., \& Drewes, J. E. (2008). Produced water in the Western United States: geographical distribution, occurrence, and composition. Environmental Engineering Science, 25(2), 239-246. 
Birol, F., Corben, J., Argiri, M., Baroni, M., Corbeau, A. S., Cozzi, L., \& Yangisawa, A. (2011). Are we entering a golden age of gas. IEA World Energy Outlook.

Bishop, R. E.(n. d.). Management of Waste Fluids from Natural Gas Exploration and Production: Comparison of New York State and Delaware River Basin Commission Regulations. Delaware Riverkeeper Network.

BP Energy (2014). BP Energy Outlook 2035. BP plc, London, United Kingdom. Available online: bp.com/energyoutlook (accessed 2015/04/28).

Brookhaven Instruments Inc. (1995). 90Plus/BI-MAS Multi Angle Particle Sizing Option Operation Manual.

Bryant, G., \& Thomas, J. C. (1995). Improved particle size distribution measurements using multiangle dynamic light scattering. Langmuir, 11(7), 2480-2485.

Chastain, J., \& King, R. C. (Eds.). (1992). Handbook of X-ray photoelectron spectroscopy: a reference book of standard spectra for identification and interpretation of XPS data ( $\mathrm{p}$. 261). Eden Prairie, MN: Perkin-Elmer.

Clark, C. E., \& Veil, J. A. (2009). Produced water volumes and management practices in the United States (No. ANL/EVS/R-09-1). Argonne National Laboratory (ANL).

Colorado Oil \& Gas Association(COGA). (2015) Water Use Fast Facts. (Available online: http://www.coga.org/pdfs_facts/WaterUse_Fast_Fact.pdf).

Demri, B., \& Muster, D. (1995). XPS study of some calcium compounds. Journal of materials processing technology, 55(3), 311-314.

Deng, S., Yu, G., Chen, Z., Wu, D., Xia, F., \& Jiang, N. (2009). Characterization of suspended solids in produced water in Daqing oilfield. Colloids and Surfaces A: Physicochemical and Engineering Aspects, 332(1), 63-69. 
Di Pierro, S., Gnos, E., Grobety, B. H., Armbruster, T., Bernasconi, S. M., \& Ulmer, P. (2003).

Rock-forming moissanite (natural $\alpha$-silicon carbide).American Mineralogist, 88(11-12), 1817-1821.

Doman L. (2015). U.S. remained world's largest producer of petroleum and natural gas hydrocarbons in 2014. (Available online:

http://www.eia.gov/todayinenergy/detail.cfm?id=20692).

EIA. (2015a). U.S Field production of crude oil. (Available online:

http://www.eia.gov/dnav/pet/hist/LeafHandler.ashx?n=PET\&s=MCRFPUS2\&f=A)

(Accessed 04/30/2015)

EIA. (2015b). U.S. dry natural gas production. (Available online:

http://www.eia.gov/dnav/ng/hist/n9070us2A.htm) (Accessed 04/30/2015)

EIA. (2015c). United States shale gas maps (available online:

http://www.eia.gov/oil_gas/rpd/shale_gas.pdf) (accessed 4/30/2015)

Ellsworth, W. L. (2013). Injection-induced earthquakes. Science, 341(6142), 1225942.

Fakhru'l-Razi, A., Pendashteh, A., Abdullah, L. C., Biak, D. R. A., Madaeni, S. S., \& Abidin, Z. Z. (2009). Review of technologies for oil and gas produced water treatment. Journal of Hazardous Materials, 170(2), 530-551.

Fehler, M., House, L., \& Kaieda, H. (1987). Determining planes along which earthquakes occur: method and application to earthquakes accompanying hydraulic fracturing. Journal of Geophysical Research: Solid Earth (1978-2012), 92(B9), 9407-9414.

Gonzalez-Elipe, A. R., Espinos, J. P., Munuera, G., Sanz, J., \& Serratosa, J. M. (1988). Bondingstate characterization of constituent elements in phyllosilicate minerals by XPS and NMR. The Journal of Physical Chemistry, 92(12), 3471-3476. 
Goodwin, S., Carlson, K., Bai, B., Rein, L., Knox, K., \& Douglas, C. (2013). Improved Water Use Estimates for Drilling and Hydrualic Fracturing in Northeastern Colorado. Journal of Water Resource and Protection, 5(12), 1262.

Guerra, K., Dahm, K., \& Dundorf, S. (2011). Oil and gas produced water management and beneficial use in the Western United States. US Department of the Interior, Bureau of Reclamation.

Haasch, R. T. (2014). X-Ray Photoelectron Spectroscopy (XPS) and Auger Electron Spectroscopy (AES). In Practical Materials Characterization (pp. 93-132). Springer New York.

Huang, F., Gundewar, R., Steed, D., \& Loughridge, B. (2006). Feasibility of using produced water for crosslinked gel-based hydraulic fracturing. VDI BERICHTE, 1940, 159.

Igunnu, E. T., \& Chen, G. Z. (2012). Produced water treatment technologies. International Journal of Low-Carbon Technologies, cts049.

IHS Global Insight. (2011). The economic and employment contributions of shale gas in the United States.Prepared for America's Natural Gas Alliance by IHS Global Insight (USA), Washington, DC: America's Natural Gas Alliance.

Kimball, R. (2011). Key considerations for frac flowback/produced water reuse and treatment. In NJWEA Annual Conference (pp. 9-13).

King, G. E. (2012). Hydraulic fracturing 101: what every representative, environmentalist, regulator, reporter, investor, university researcher, neighbor and engineer should know about estimating frac risk and improving frac performance in unconventional gas and oil wells. In SPE Hydraulic Fracturing Technology Conference. Society of Petroleum Engineers. 
King, R. F., \& Morehouse, D. (1993). Drilling sideways - a review of horizontal well technology and its domestic application. US Department of Energy-Energy Information Administration April, 26.

Lechtenböhmer, S., Altmann, M., Capito, S., Matra, Z., Weindrorf, W., \& Zittel, W. (2011). Impacts of shale gas and shale oil extraction on the environment and on human health. Wuppertal Institute for Climate, Environment and Energy and Ludwig-BölkowSystemtechnik GmbH, study requested by the European Parliament's Committee on Environment, Public Health and Food Safety, IP/A/ENVI/ST/2011-07, June.

Levine, A. D., Tchobanoglous, G., \& Asano, T. (1991). Size distributions of particulate contaminants in wastewater and their impact on treatability. Water Research, 25(8), 911922.

Malvern Instruments. (2012). Dynamic light scattering: an introduction in 30 minutes. Technical Note Malvern, MRK656-01, 1-8.

Odoma, A. N., Obaje, N. G., Omada, J. I., Idakwo, S. O., \& Erbacher, J. (2015). Mineralogical, chemical composition and distribution of rare earth elements in clay-rich sediments from Southeastern Nigeria. Journal of African Earth Sciences, 102, 50-60.

Parrill, T. M., \& Chung, Y. W. (1991). Surface analysis of cubic silicon carbide (001). Surface science, 243(1), 96-112.

Powers, K. W., Brown, S. C., Krishna, V. B., Wasdo, S. C., Moudgil, B. M., \& Roberts, S. M. (2006). Research strategies for safety evaluation of nanomaterials. Part VI.

Characterization of nanoscale particles for toxicological evaluation. Toxicological Sciences, 90(2), 296-303. 
Riemer, P. (1996). Greenhouse gas mitigation technologies, an overview of the CO 2 capture, storage and future activities of the IEA greenhouse gas R\&D programme. Energy Conversion and Management, 37(6), 665-670.

Sasaki, S. (1998). Characteristics of microseismic events induced during hydraulic fracturing experiments at the Hijiori hot dry rock geothermal energy site, Yamagata, Japan. Tectonophysics, 289(1), 171-188.

US Energy Information Administration (EIA) (2014). Annual Energy Outlook 2014. Report Number: DOE/EIA-0383(2014).

Vempati, R. K., Loeppert, R. H., Dufner, D. C., \& Cocke, D. L. (1990). X-ray photoelectron spectroscopy as a tool to differentiate silicon-bonding state in amorphous iron oxides. Soil Science Society of America Journal, 54(3), 695-698.

Werne, J. P., Sageman, B. B., Lyons, T. W., \& Hollander, D. J. (2002). An integrated assessment of a "type euxinic" deposit: evidence for multiple controls on black shale deposition in the Middle Devonian Oatka Creek Formation.American Journal of Science, 302(2), 110-143.

Ziemkiewicz, P., Quaranta, J. D., \& McCawley, M. (2014). Practical measures for reducing the risk of environmental contamination in shale energy production. Environmental Science: Processes \& Impacts, 16(7), 1692-1699.

Zielinski, R. A., \& Otton, J. K. (1999). Naturally Occurring Radioactive Materials (NORM) in Produced Water and Oil-field Equipment: An Issue for Energy Industry. US Department of the Interior, US Geological Survey. 
Appendix A Particle Size Distribution

Crow Creek Pad wells CC-73 and CC-76-1

CC-73HN

Preflow

$2 / 20 / 14$

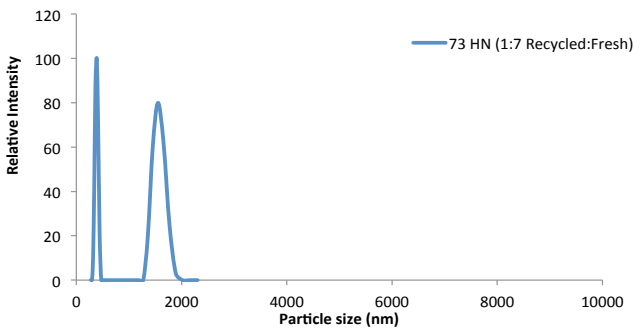

Preflow

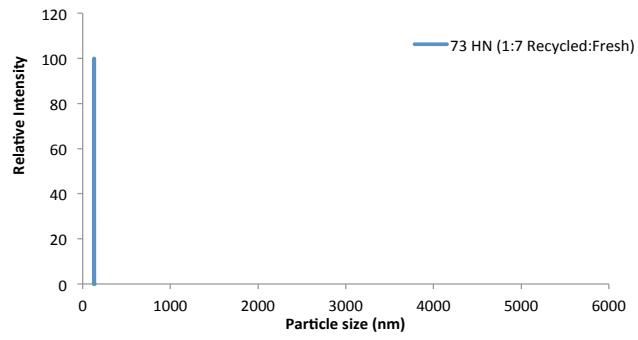

Day

1

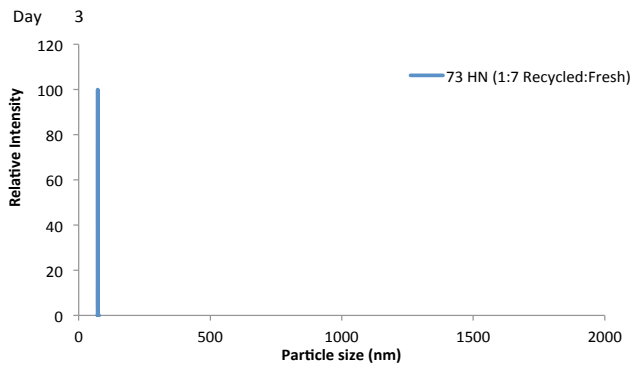

Day 4

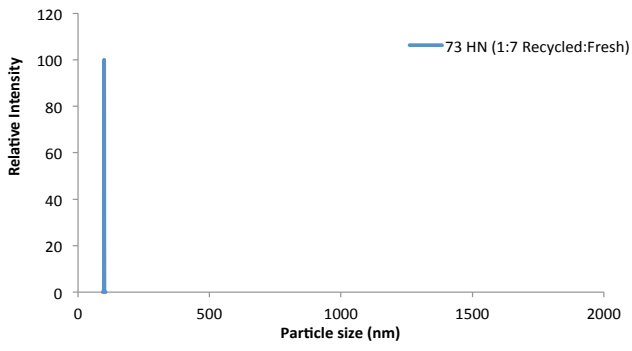

CC-76-1 MN
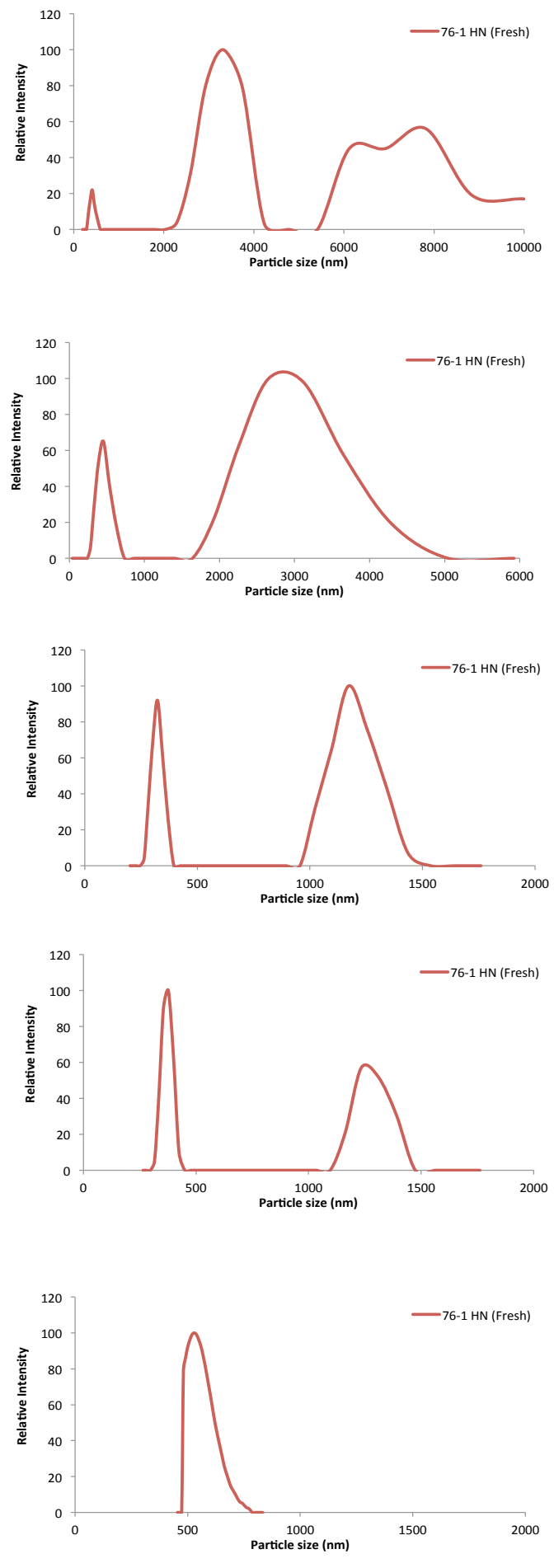

52 
Day 5
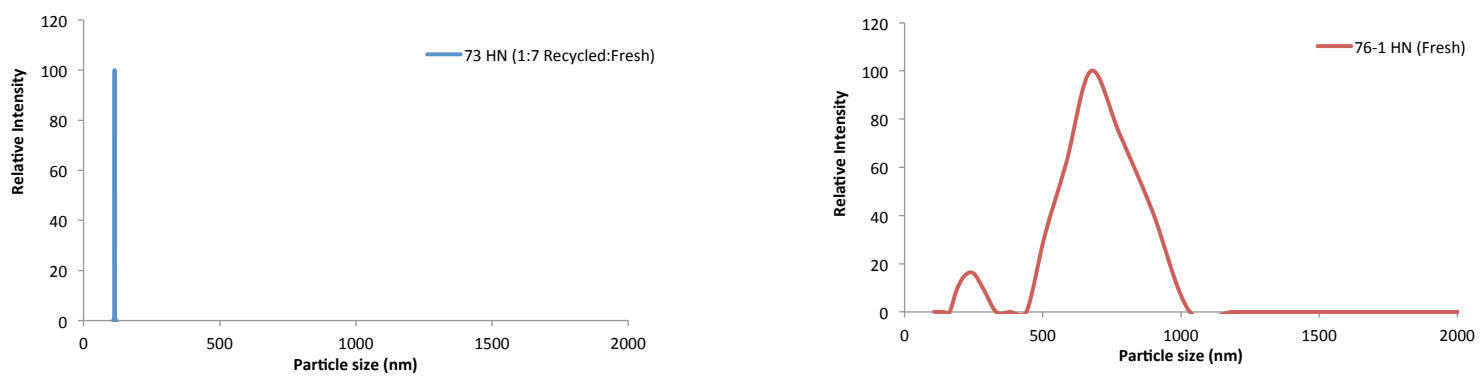

Day 6
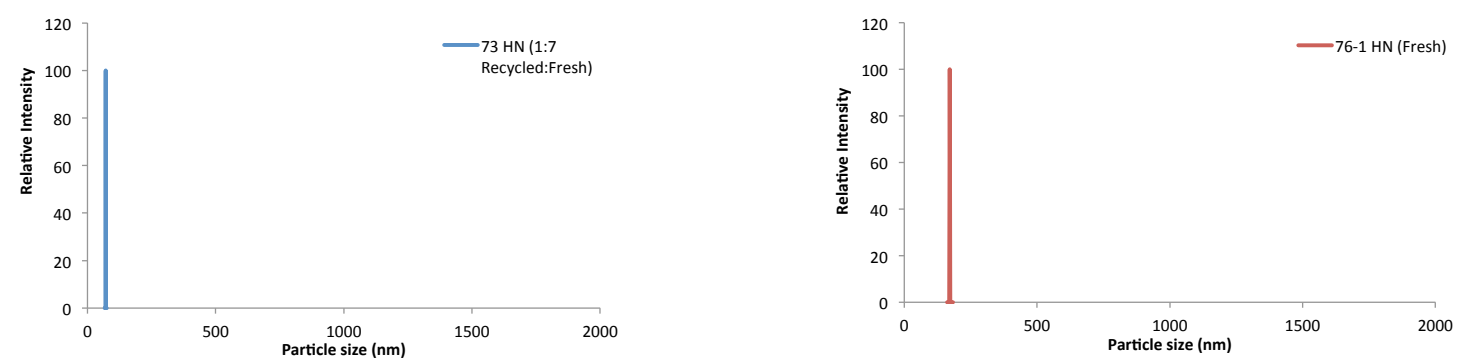

Day 7
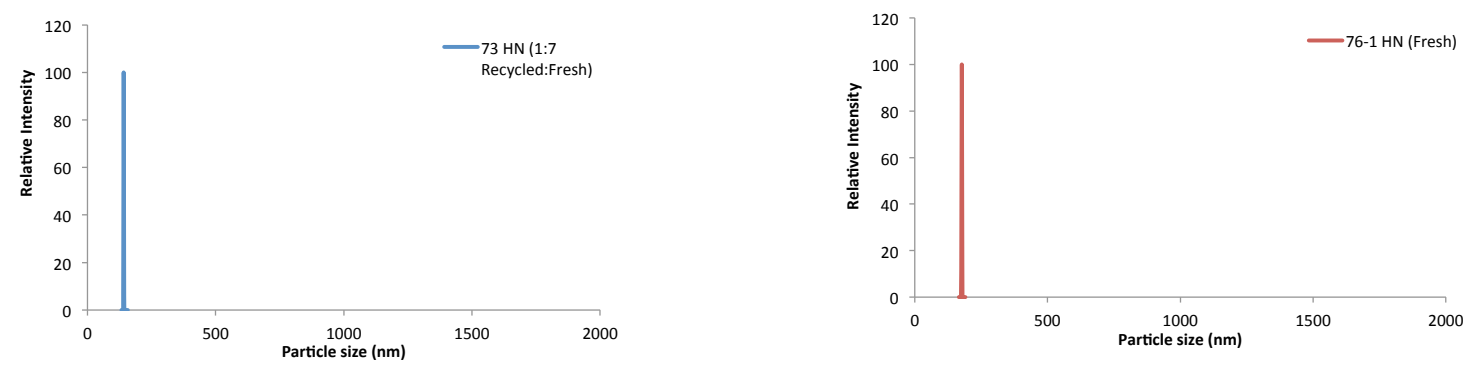

Day 8
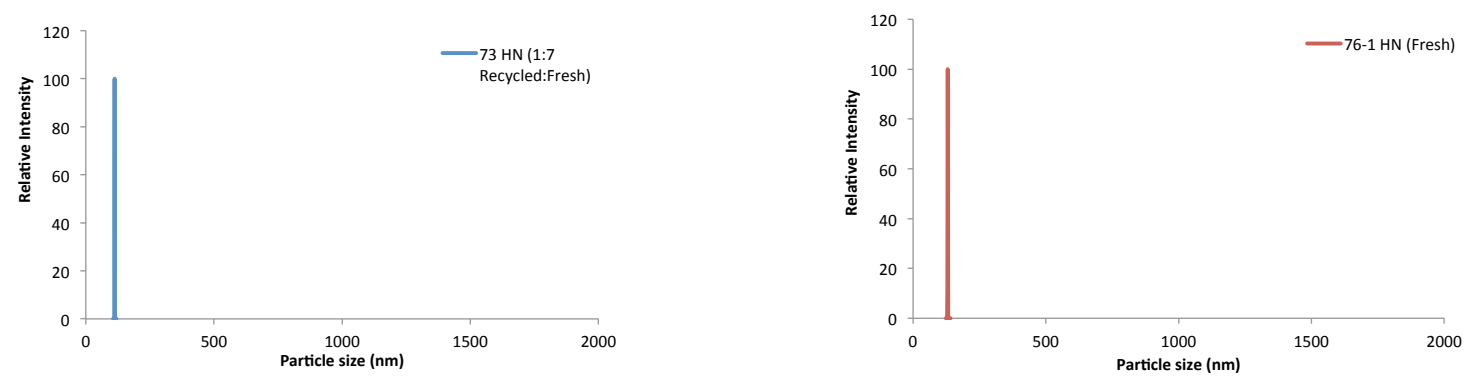

Day 9

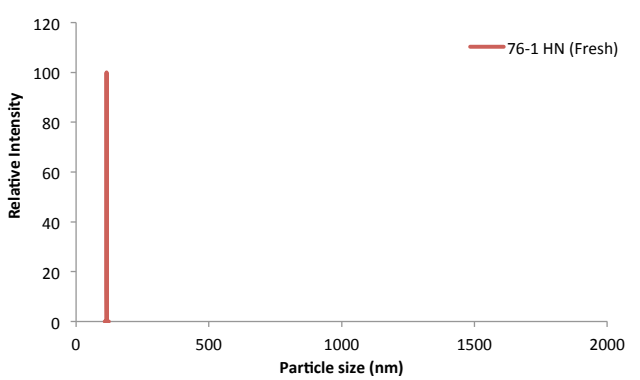


Day 11
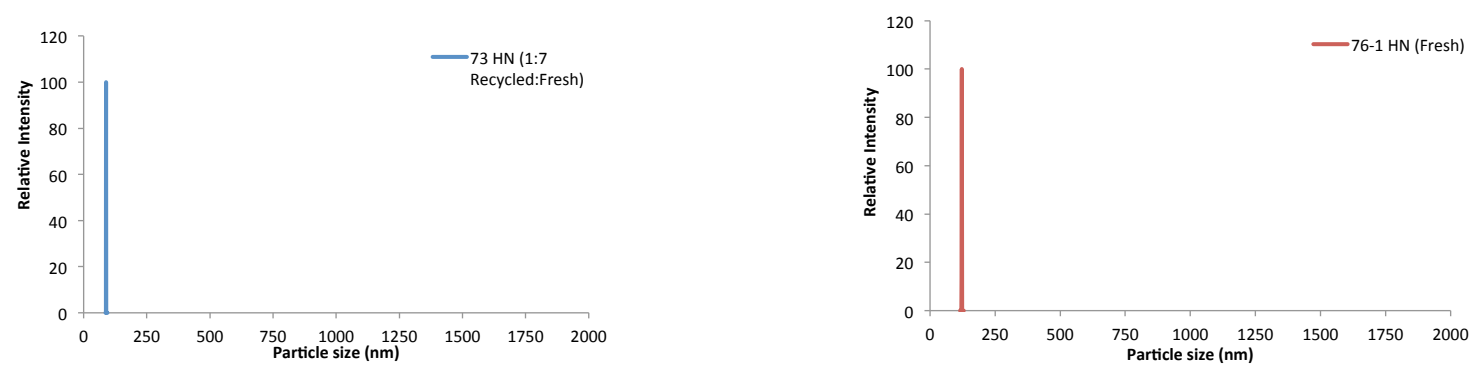

Day 12
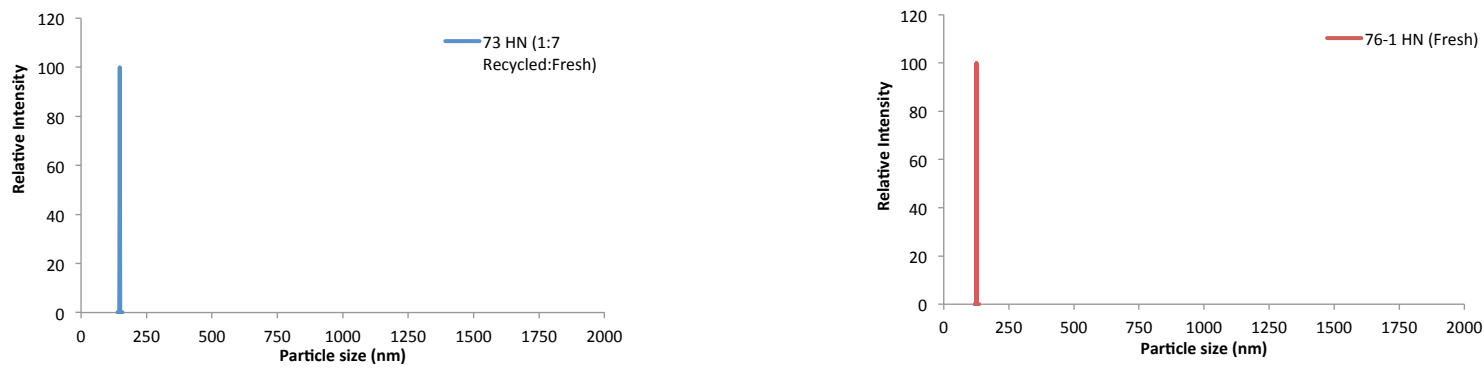

Day 13
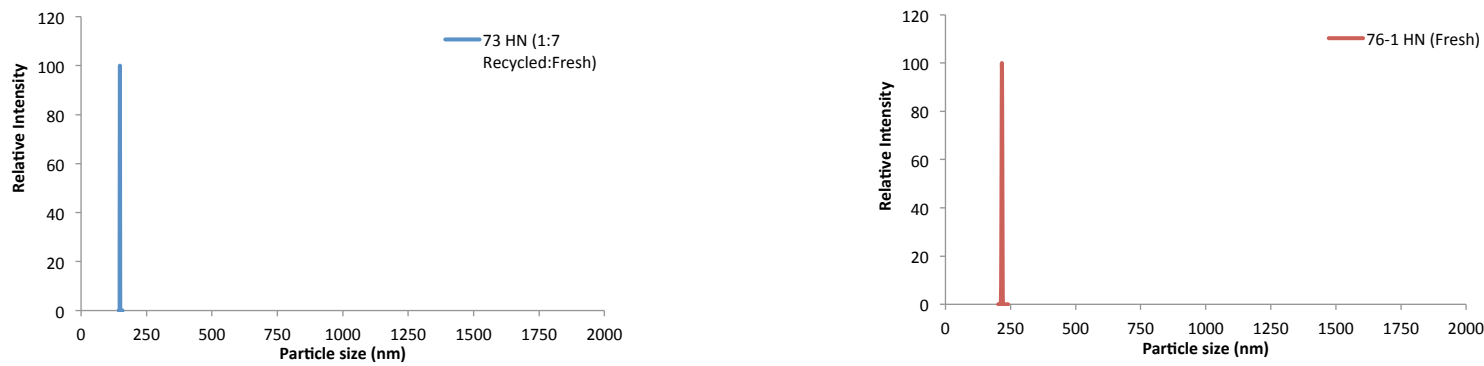

Day 14
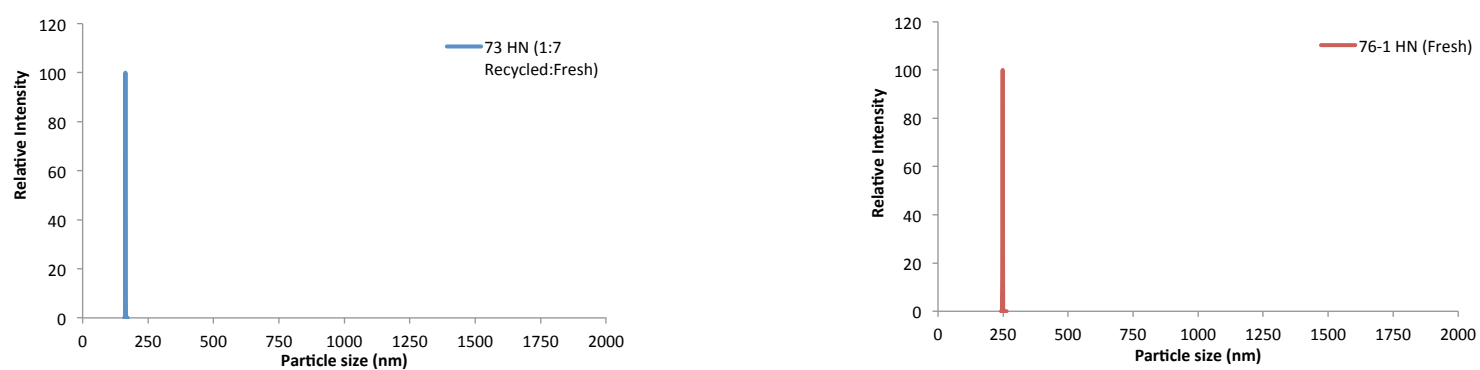

Day 15

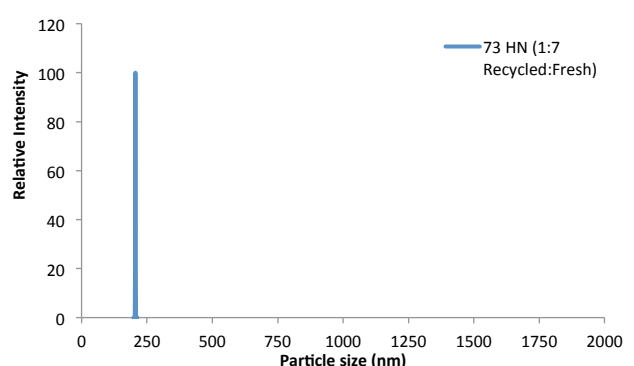


Day 18

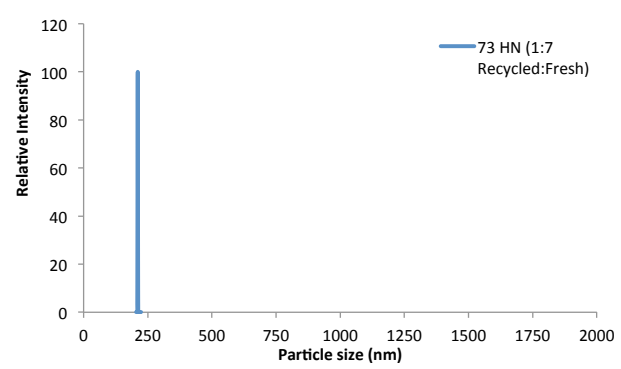

Day 21
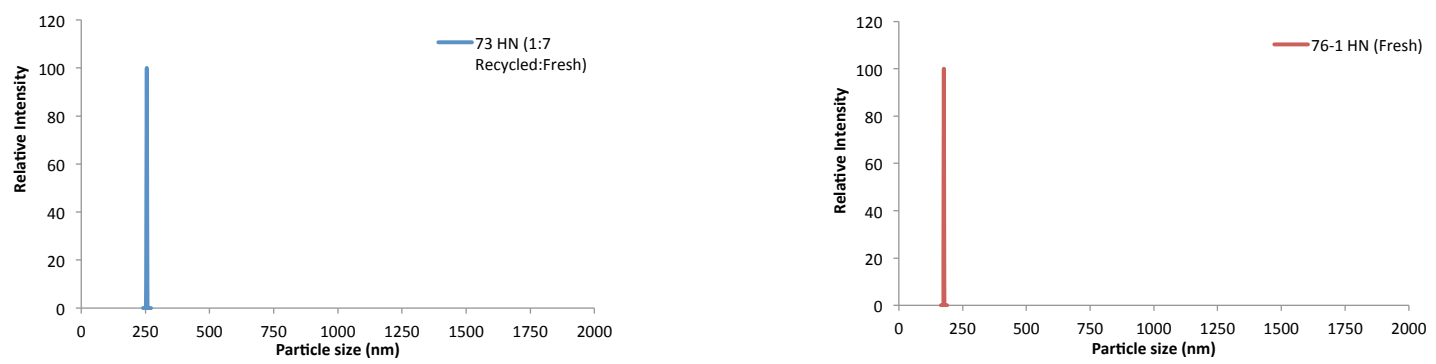

Day 24
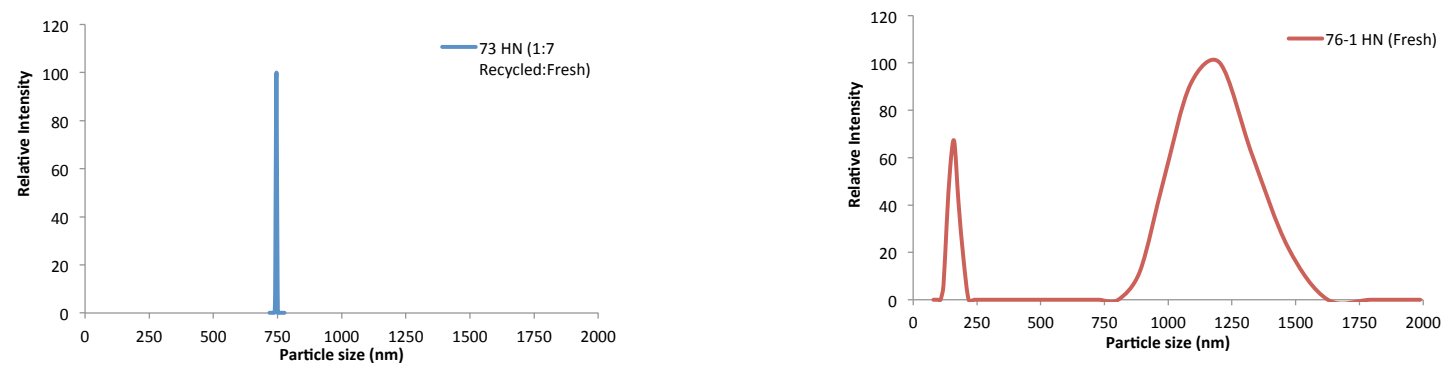

Day 30
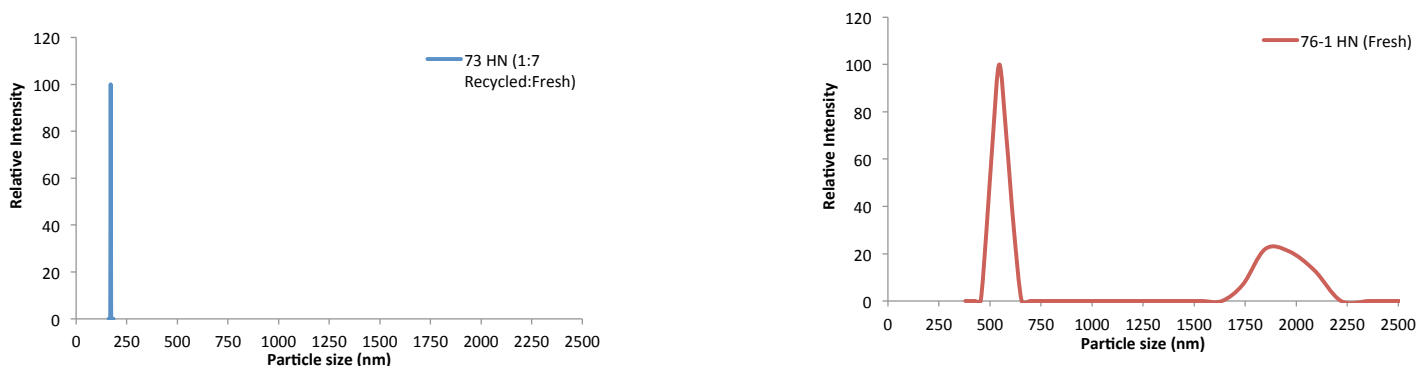
Chandler State wells 72-1, 73-1 and 74-1:

Day 1

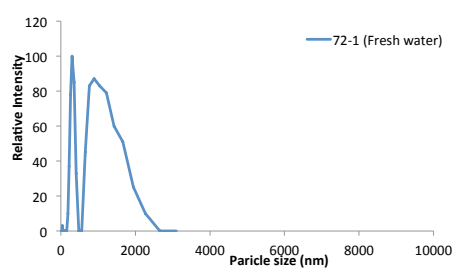

Day 2

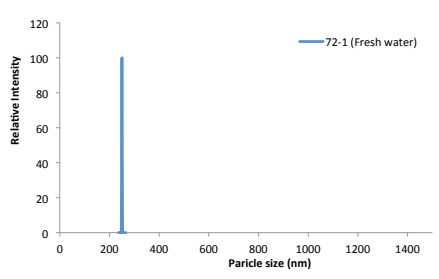

Day

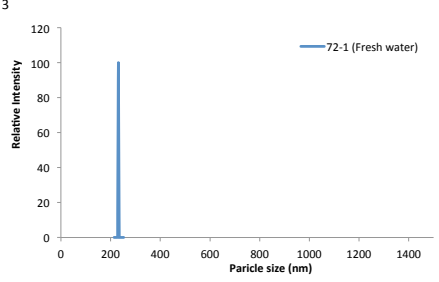

Day 5

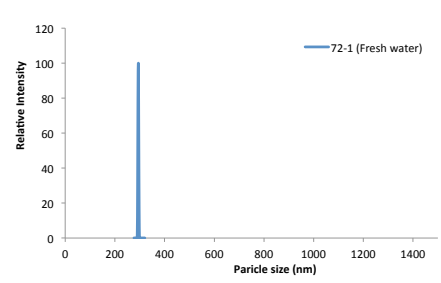

Day 6

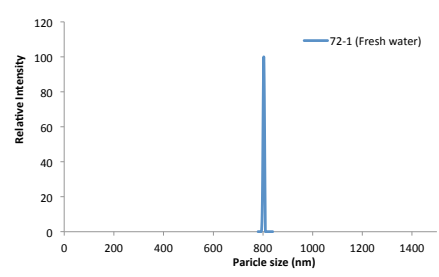

Day 10

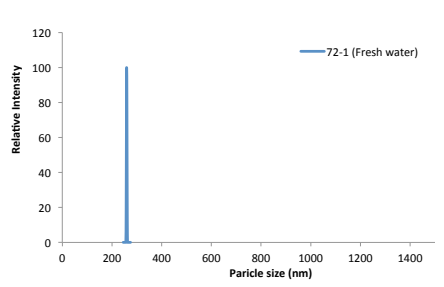

73-1 (1:7 Recycled:Fresh)
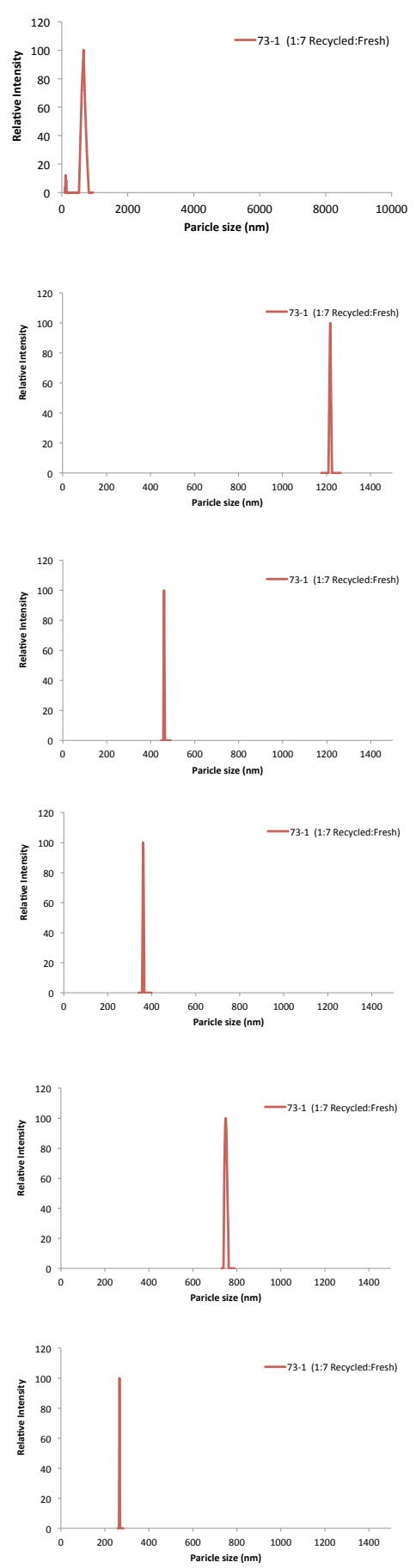

74-1 (1:5 Recycled:Fresh)
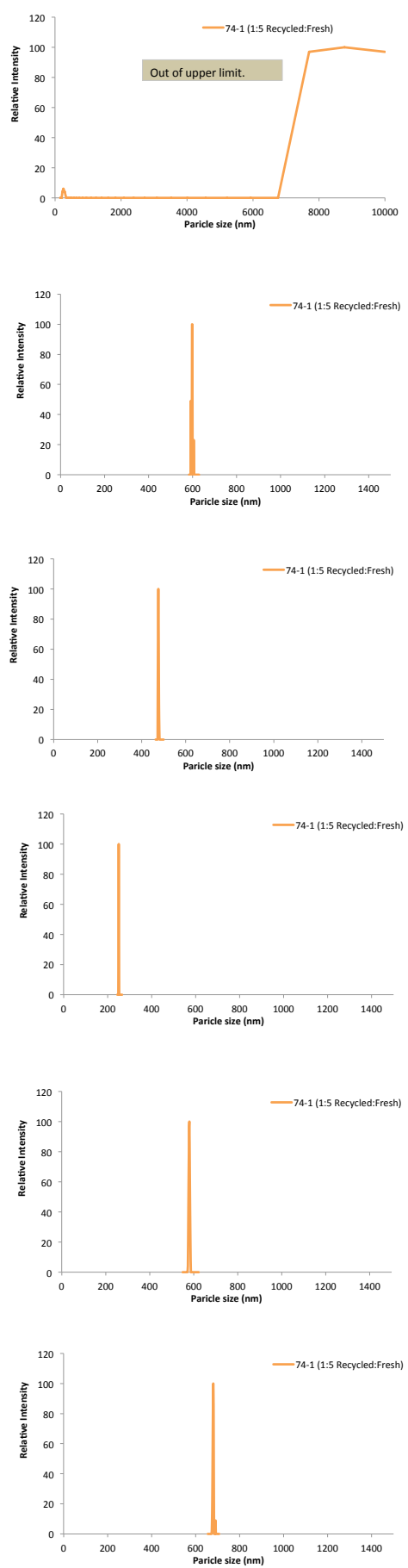
Day 14

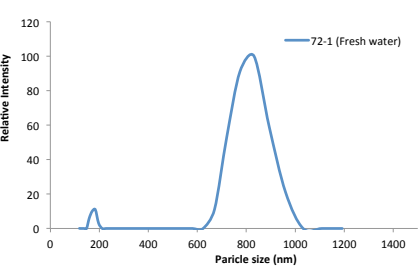

Day 20

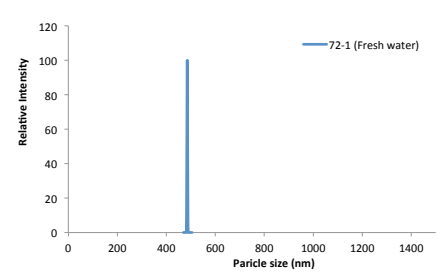

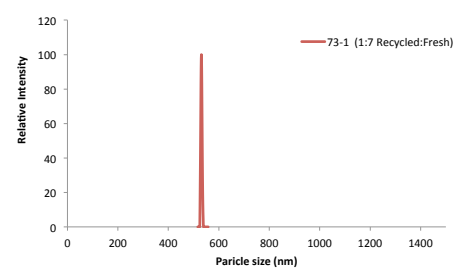

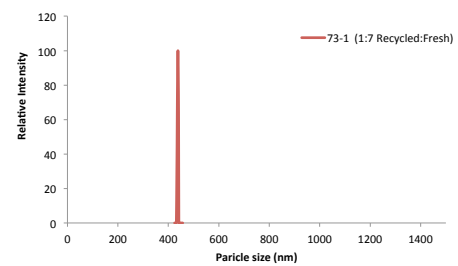

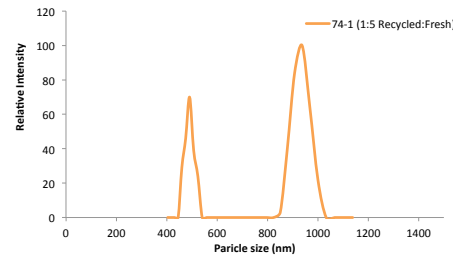

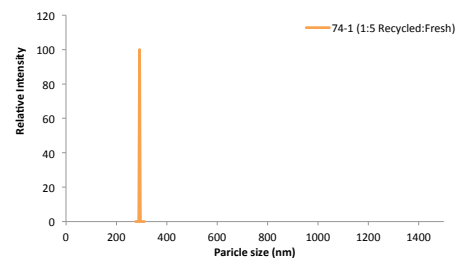




\section{Appendix B. XPS Survey Scan Spectra}

\section{CS-72-1 Day 1}

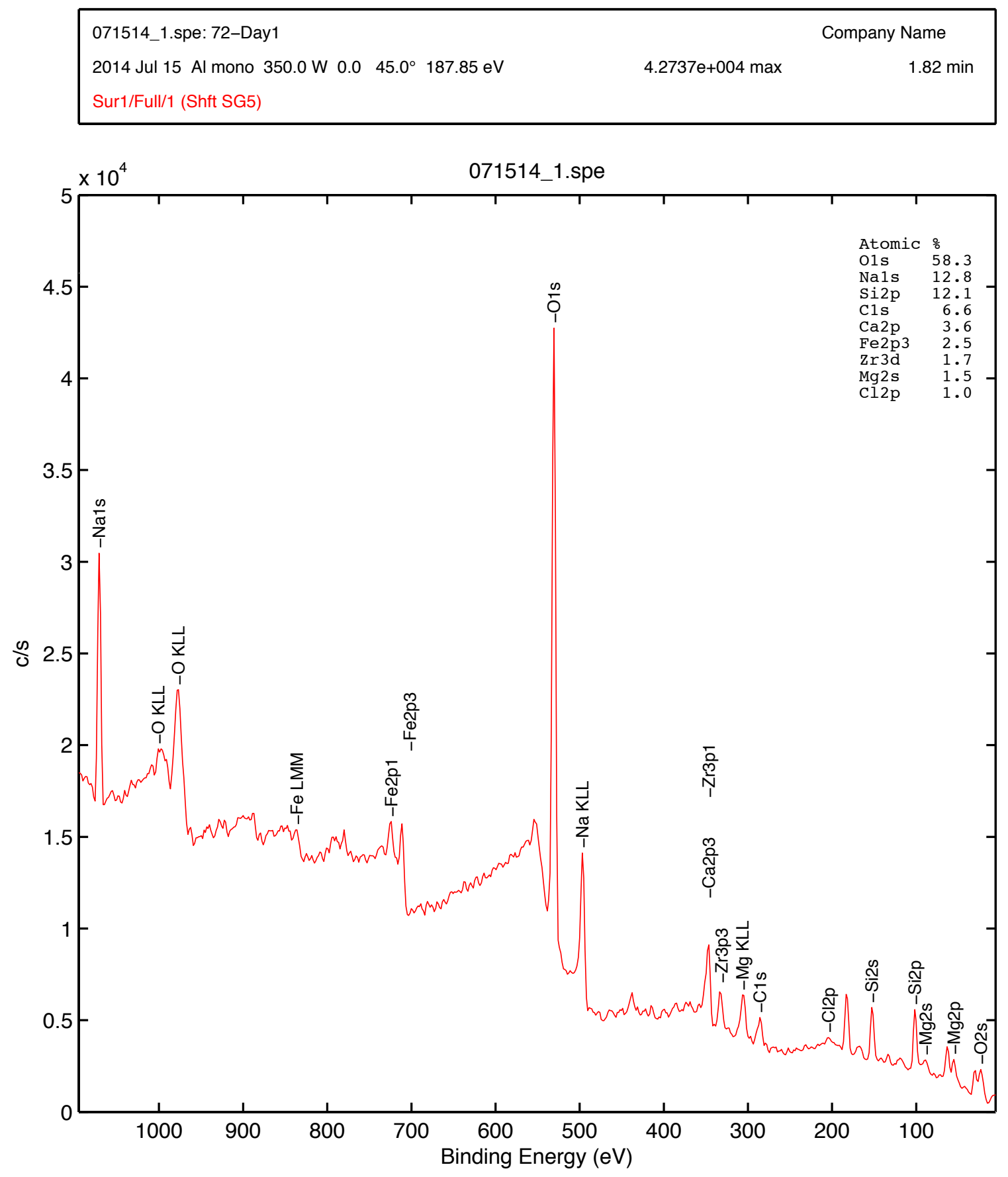


CS-73-1 day 1

\begin{tabular}{|c|c|c|}
\hline 071514_4.spe: 73-day1 & & Name \\
\hline $\begin{array}{l}2014 \text { Jul } 15 \text { Al mono } 350.0 \text { W } 0.045 .0^{\circ} 187.85 \text { eV } \\
\text { Sur1/Full/1 (Shft Shft SG5) }\end{array}$ & $8.8246 e+004 \max$ & $1.96 \mathrm{~min}$ \\
\hline
\end{tabular}

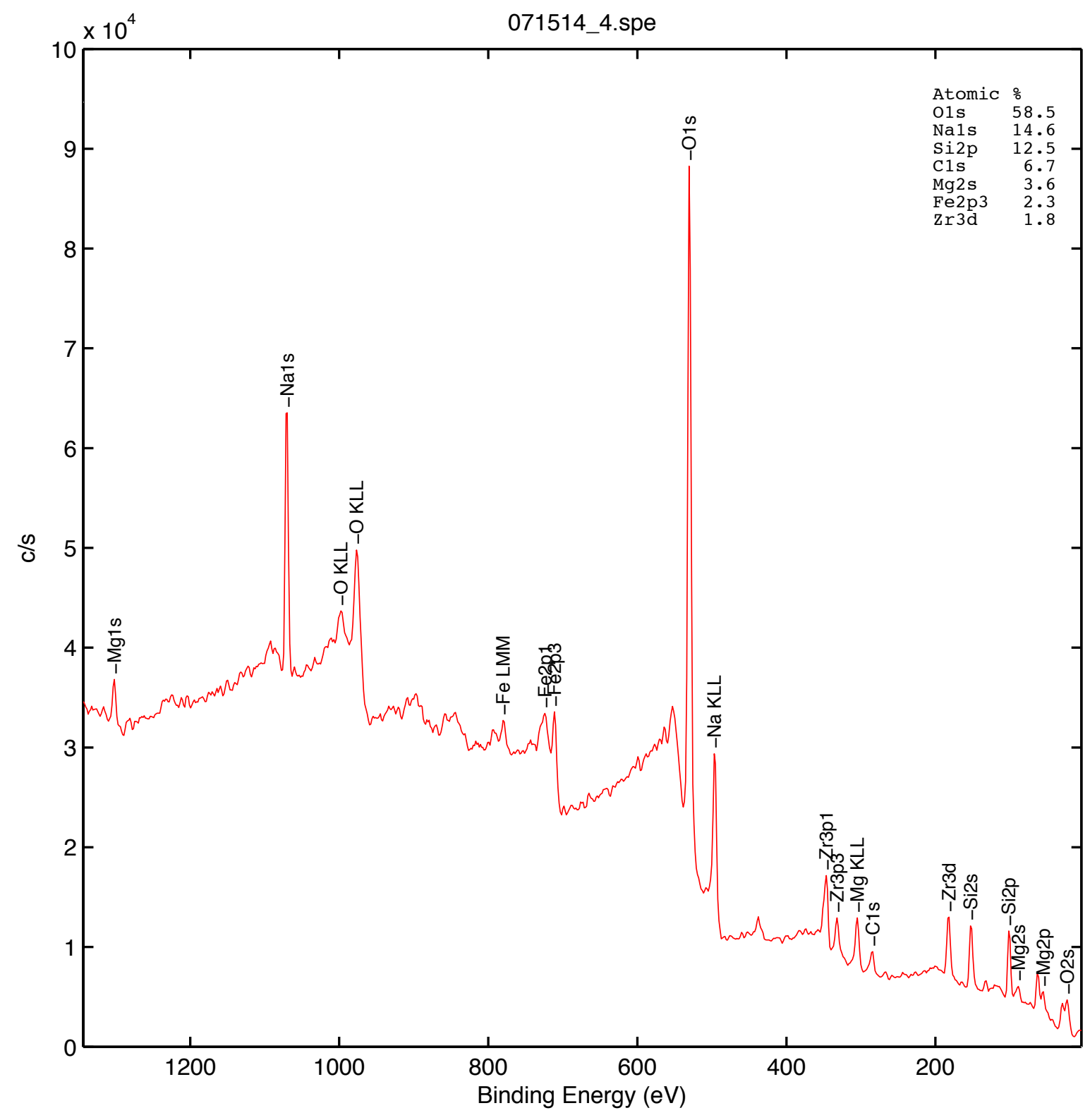


CS-74-1 day 1

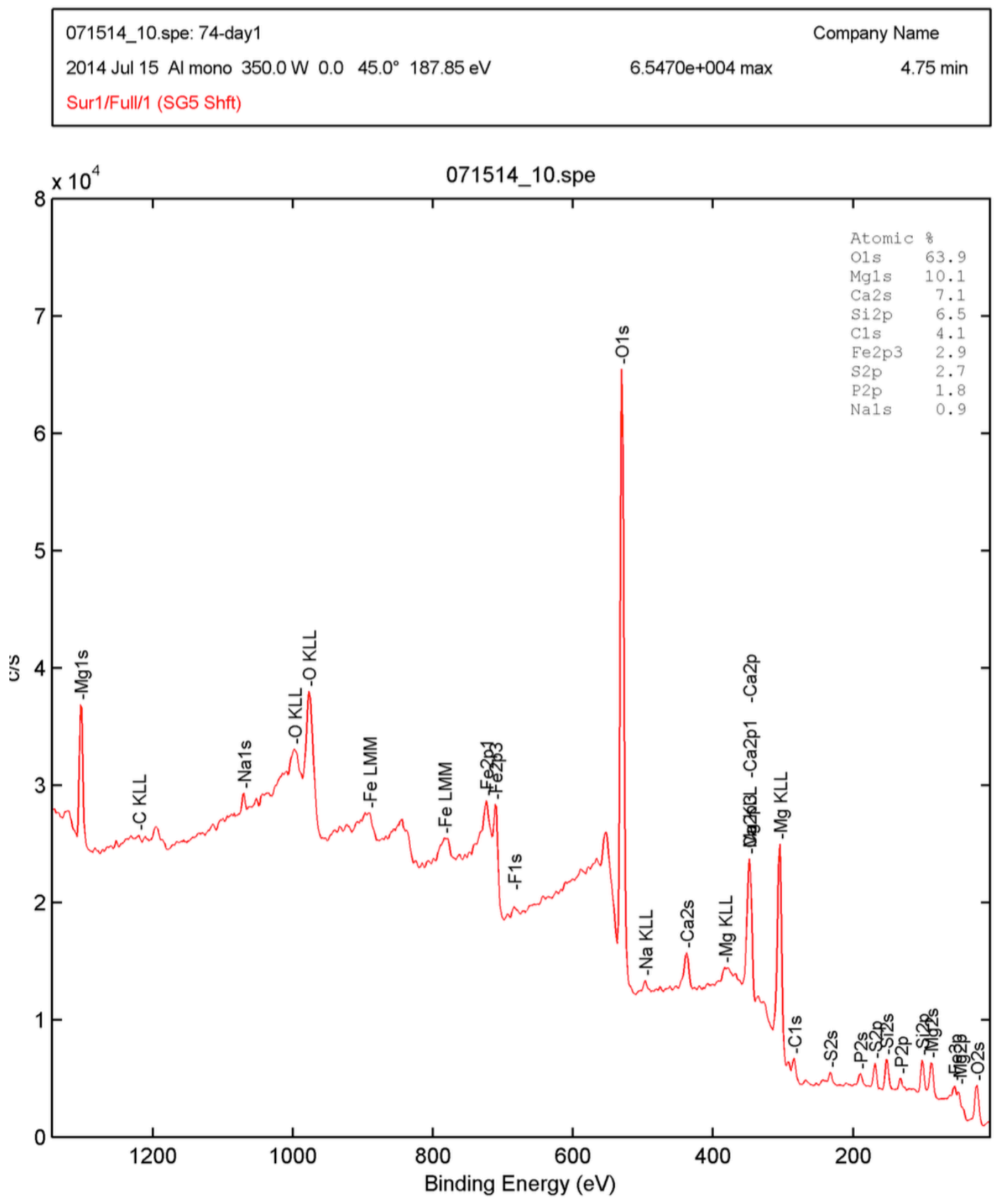


CS-72-1 day 2

\begin{tabular}{|c|c|c|}
\hline 072514_1.spe: 72_day2 & & Name \\
\hline $\begin{array}{l}2014 \text { Jul } 25 \text { Al mono } 350.0 \text { W } 0.0 \quad 45.0^{\circ} 187.85 \mathrm{eV} \\
\text { Sur1/Full/1 (SG5 Shft Shft) }\end{array}$ & $8.2692 e+004 \max$ & $4.77 \mathrm{~min}$ \\
\hline
\end{tabular}

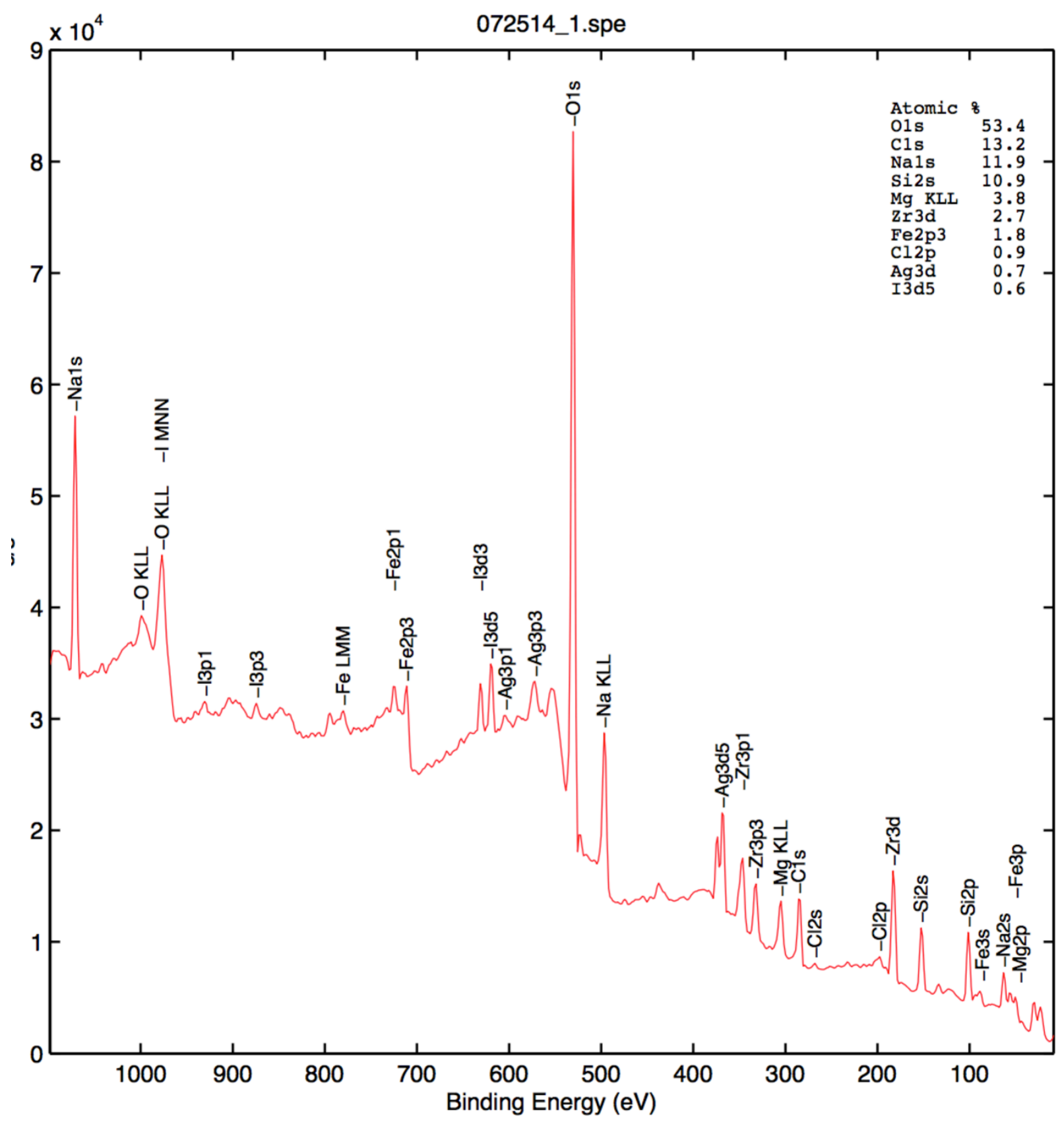


CS-73-1 day 2

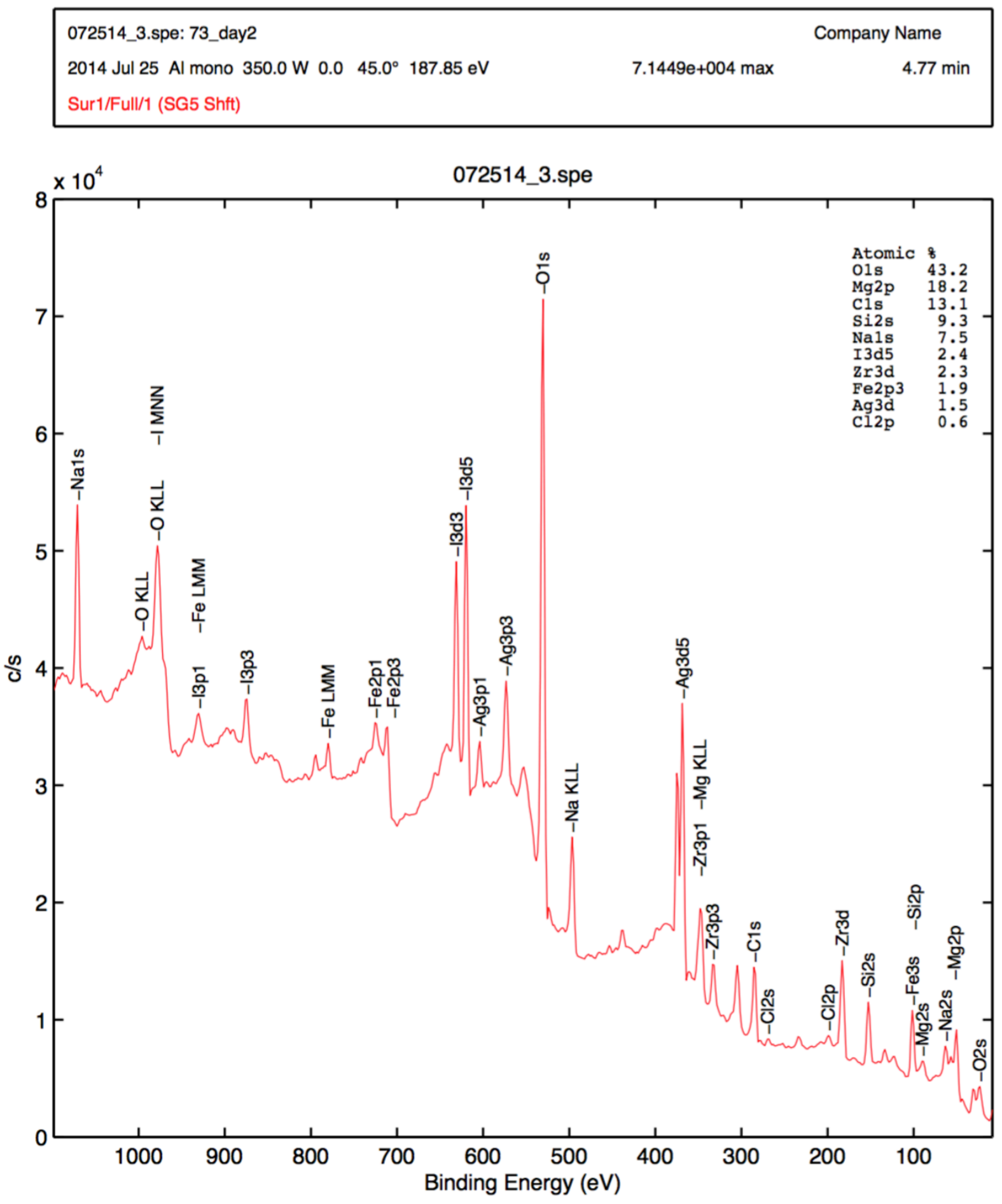


CS-74-1 day 2

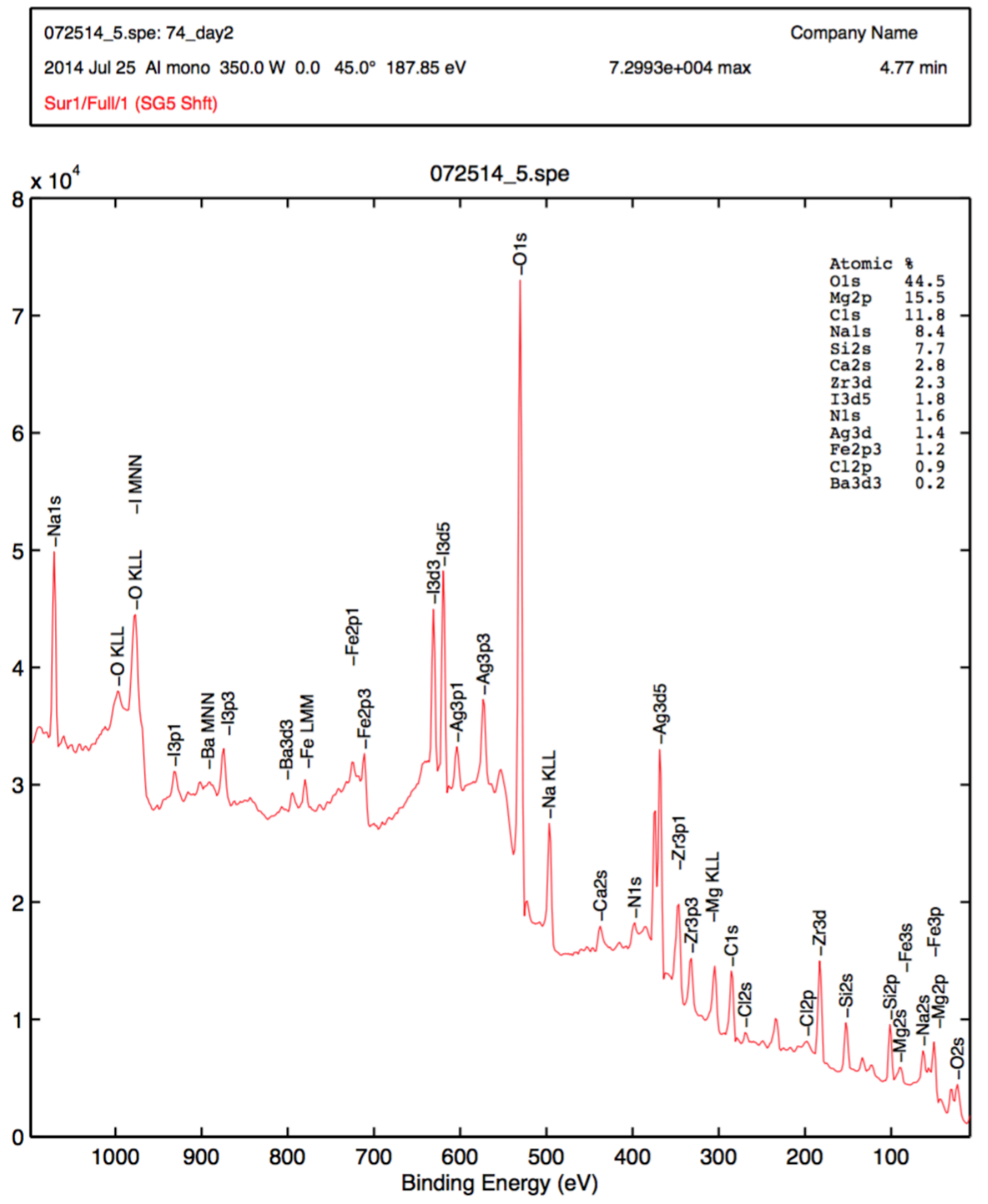


CS-72-1 day 6

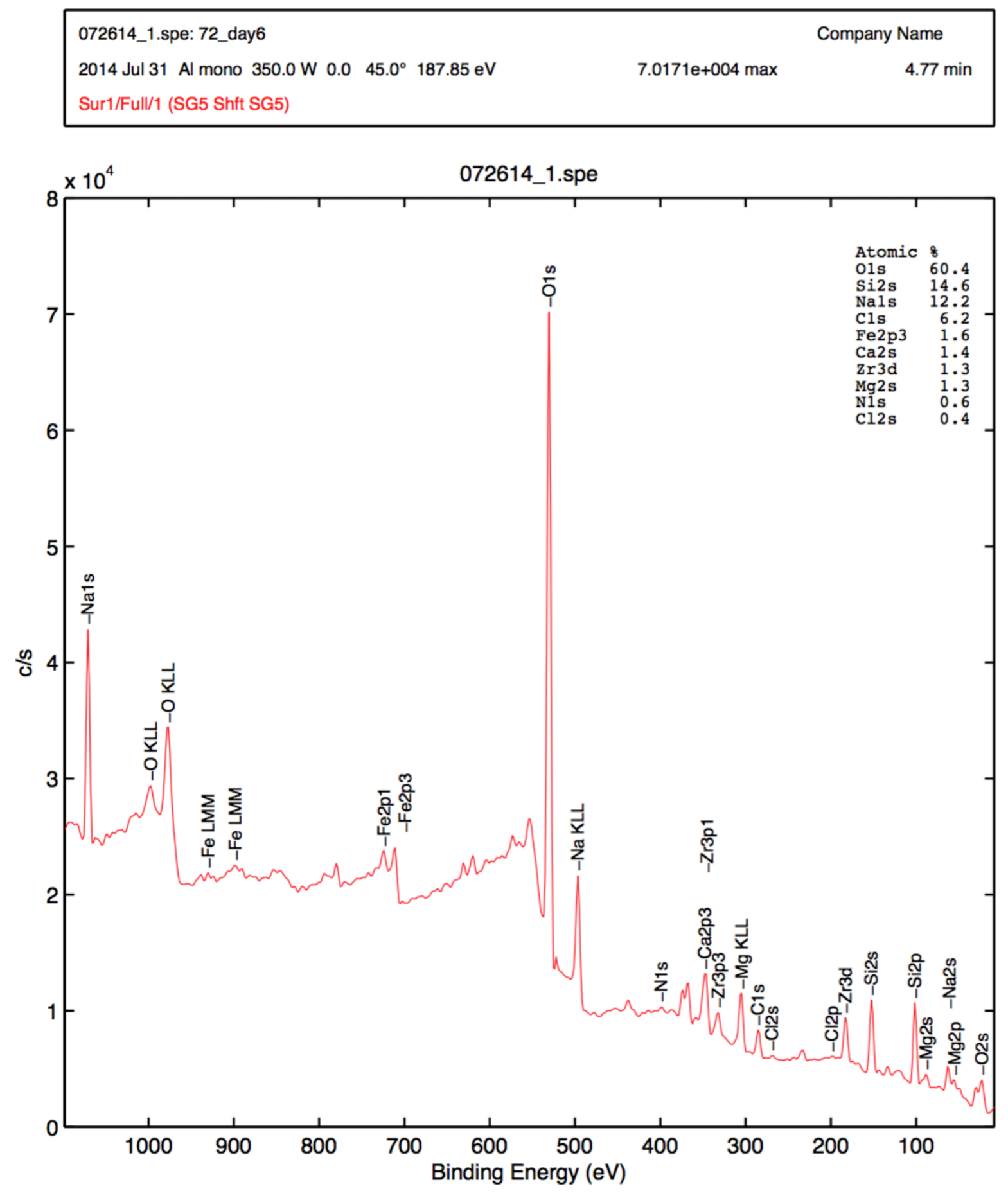


CS-73-1 day 6

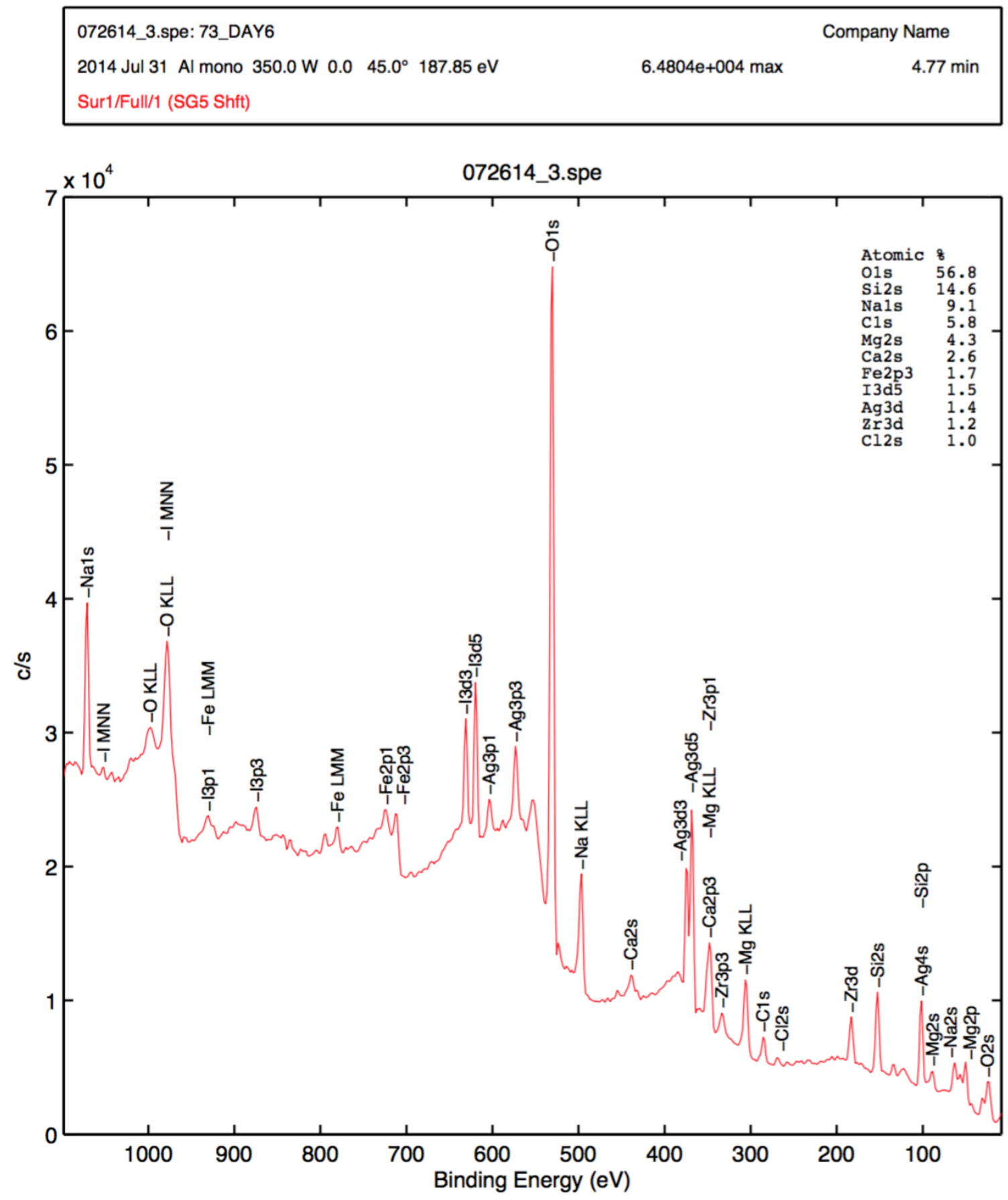


CS-74-1 day 6

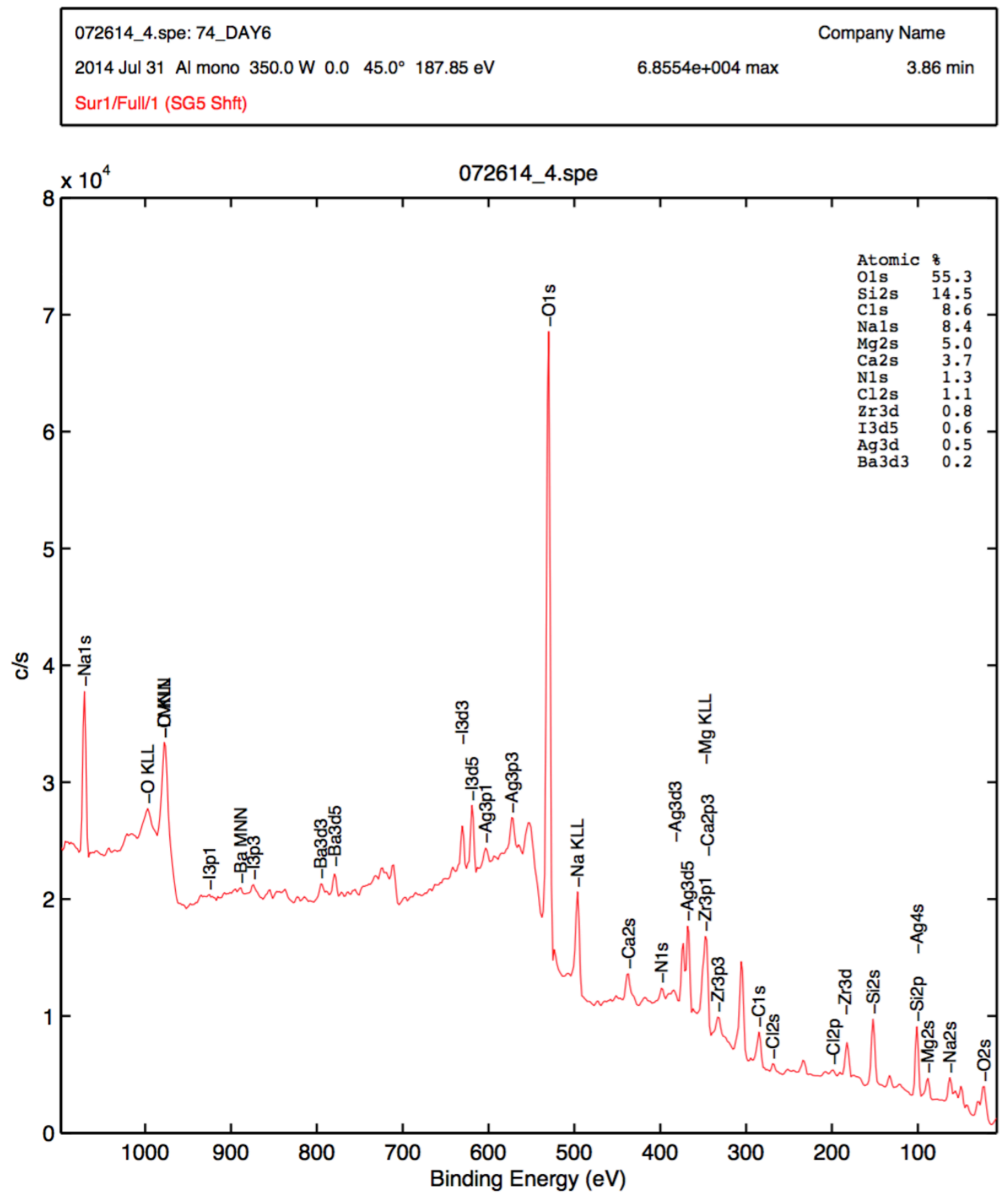


CS-72-1 day 10

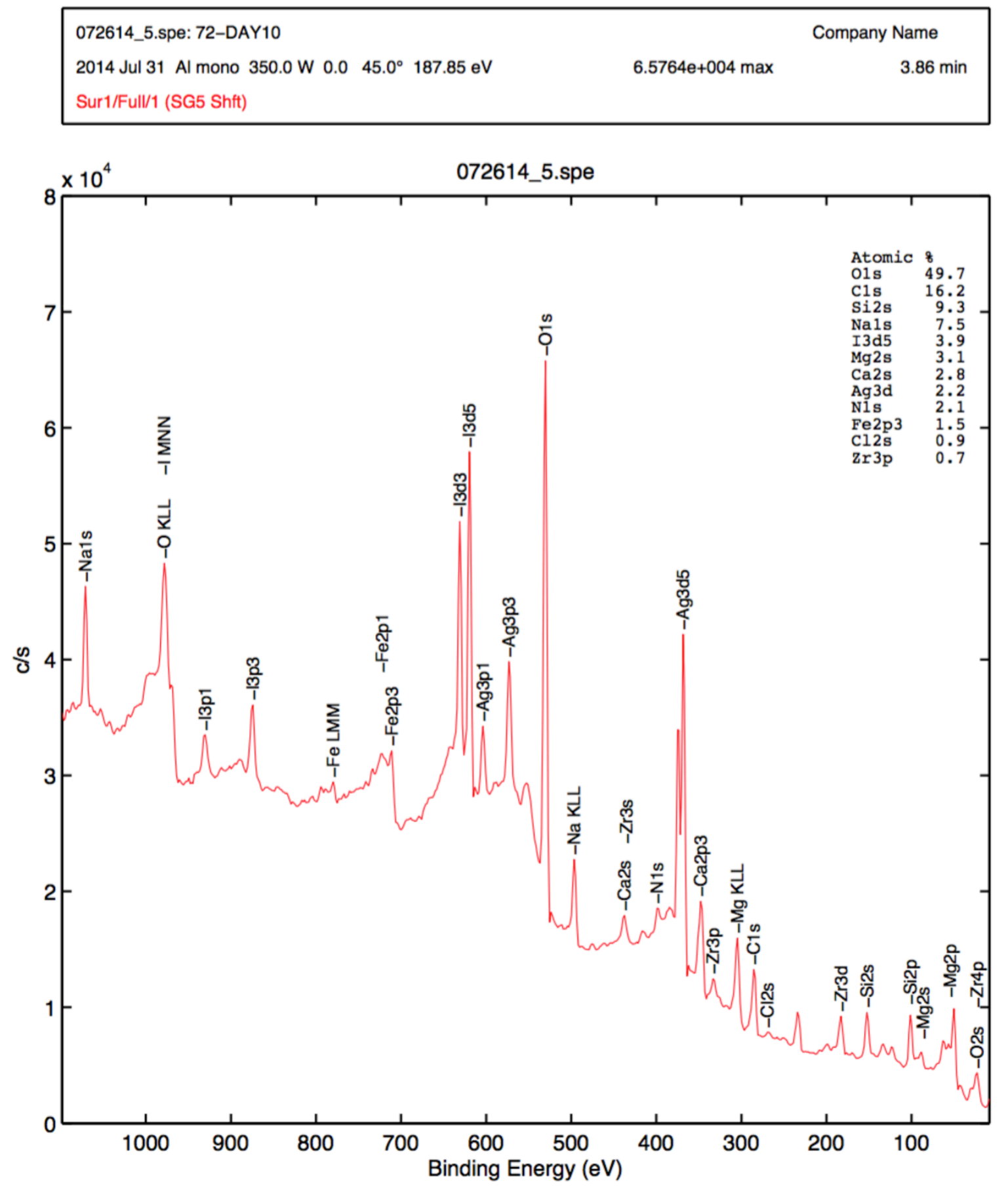


CS-73-1 day 10

072614_6.spe: 73_DAY10

2014 Jul 31 Al mono 350.0 W $0.0 \quad 45.0^{\circ} 187.85 \mathrm{eV}$

Company Name

Sur1/Full/1 (SG5 Shft)

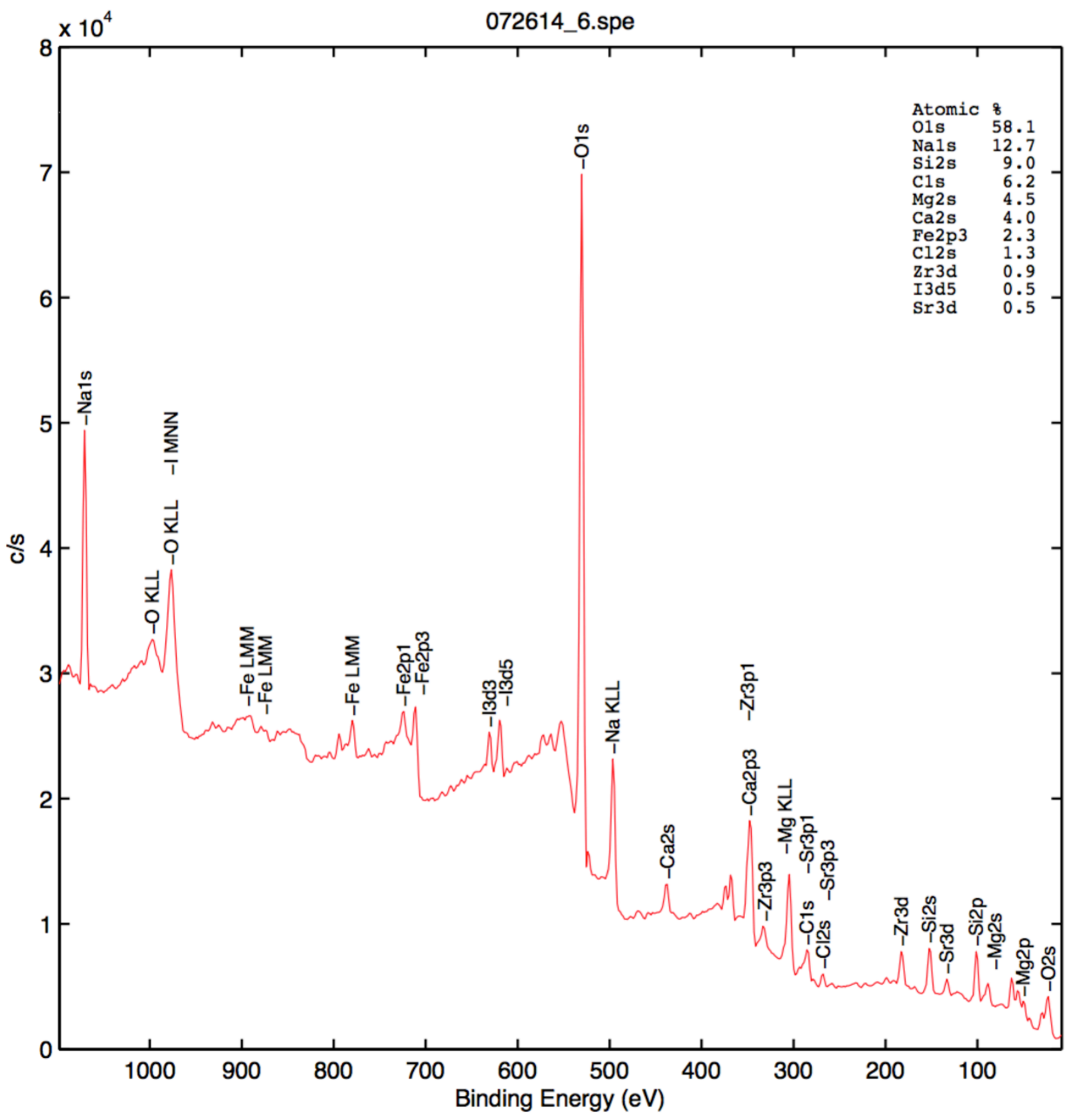


CS-74-1 day 10

\begin{tabular}{|c|c|c|}
\hline 072614_7.spe: 74_DAY10 & & Name \\
\hline $\begin{array}{l}2014 \text { Jul } 31 \text { Al mono } 350.0 \text { W } 0.045 .0^{\circ} 187.85 \mathrm{eV} \\
\text { Sur1/Full/1 (SG5 Shft) }\end{array}$ & $7.6313 e+004 \max$ & $3.86 \mathrm{~min}$ \\
\hline
\end{tabular}

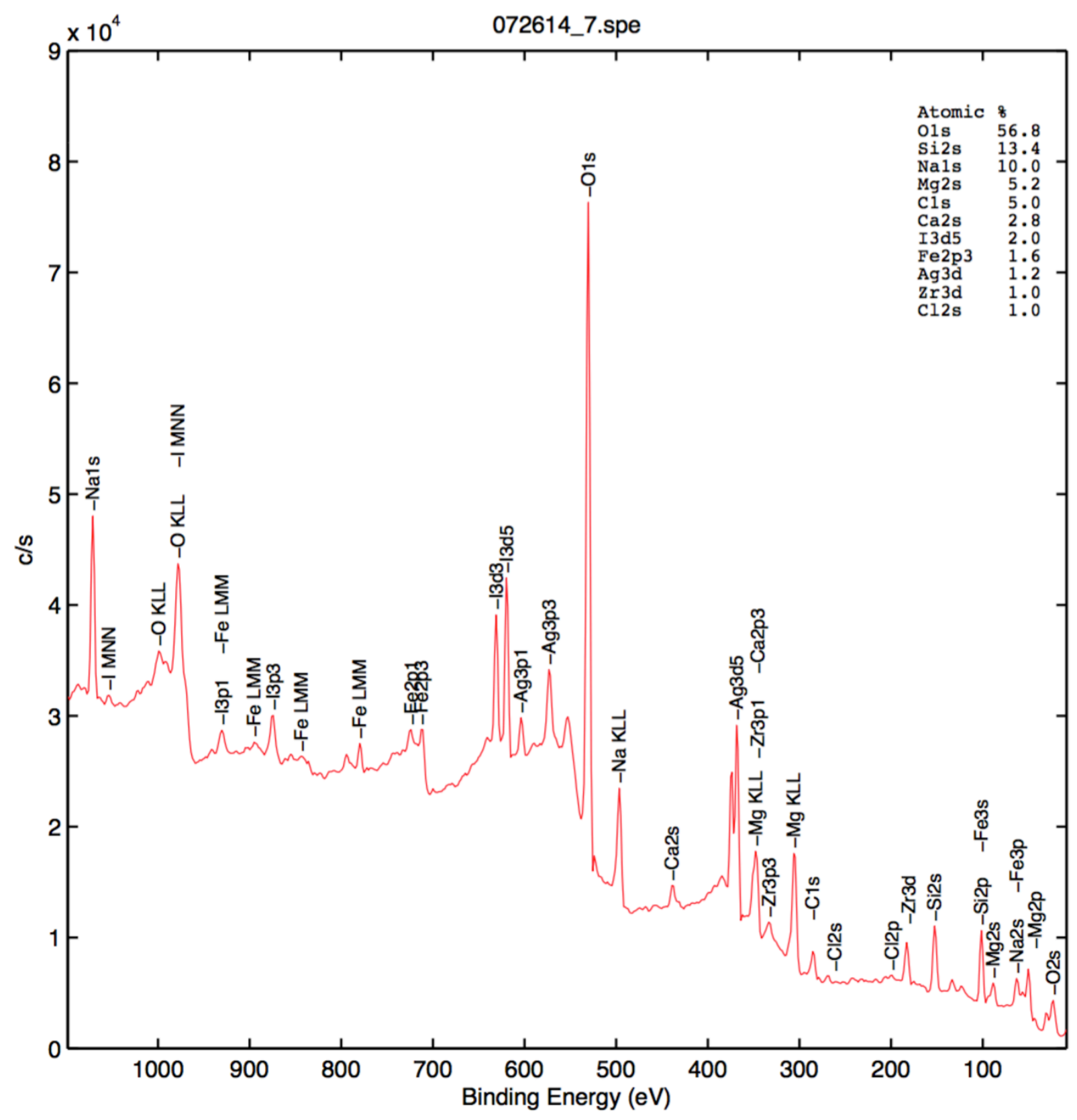


CS-72-1 day 20

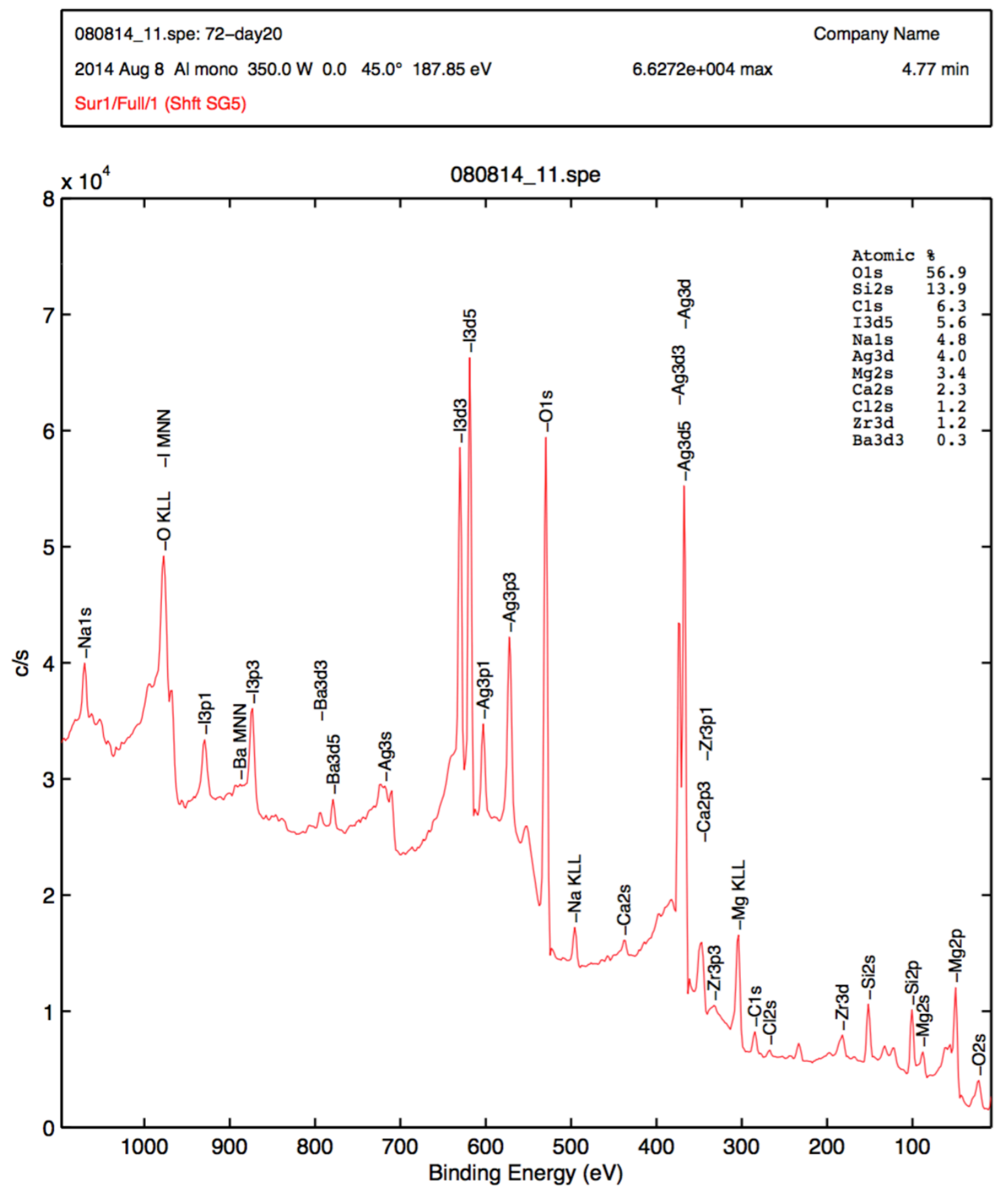


CS-73-1 day 20

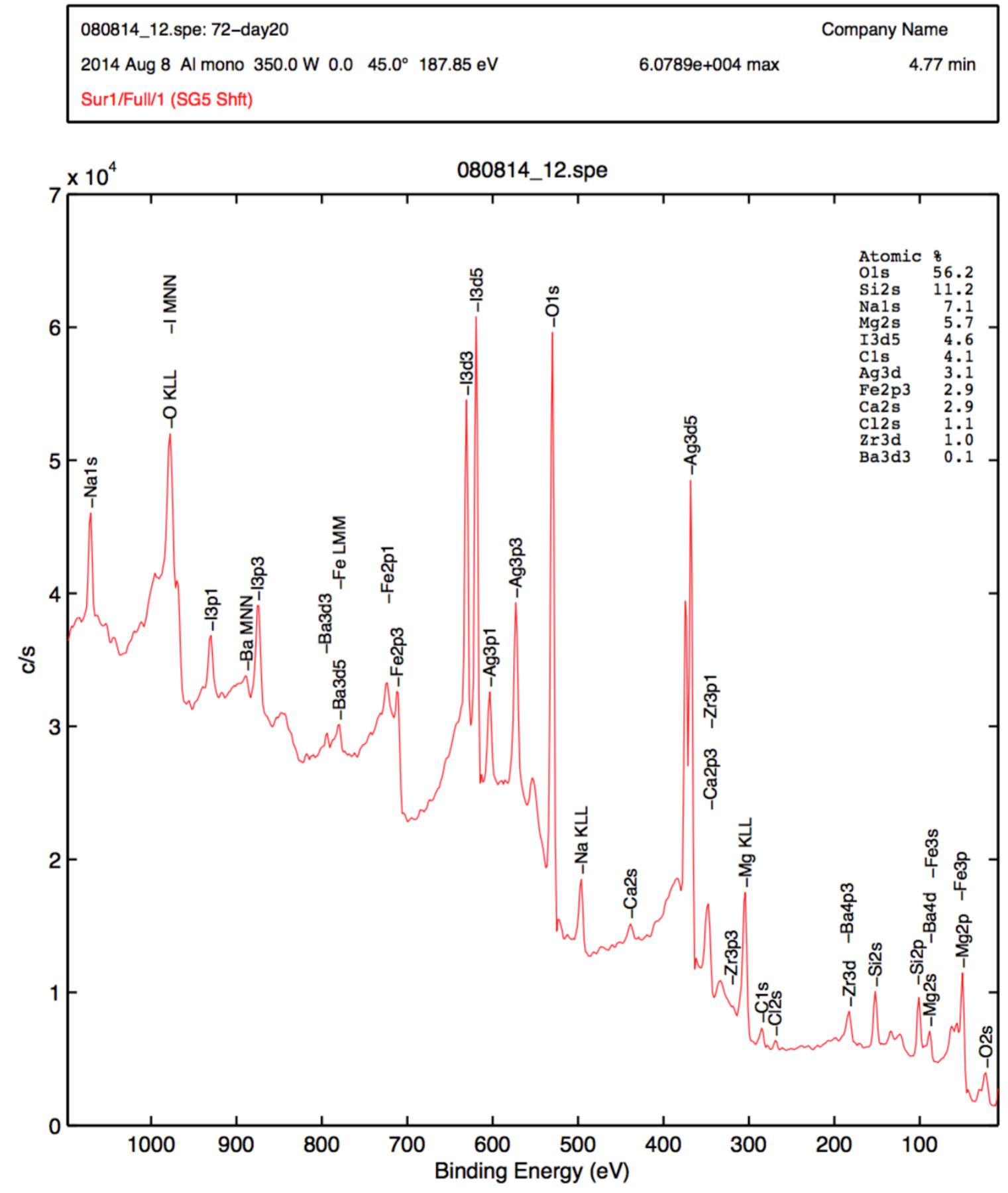


CS-74-1 day 20

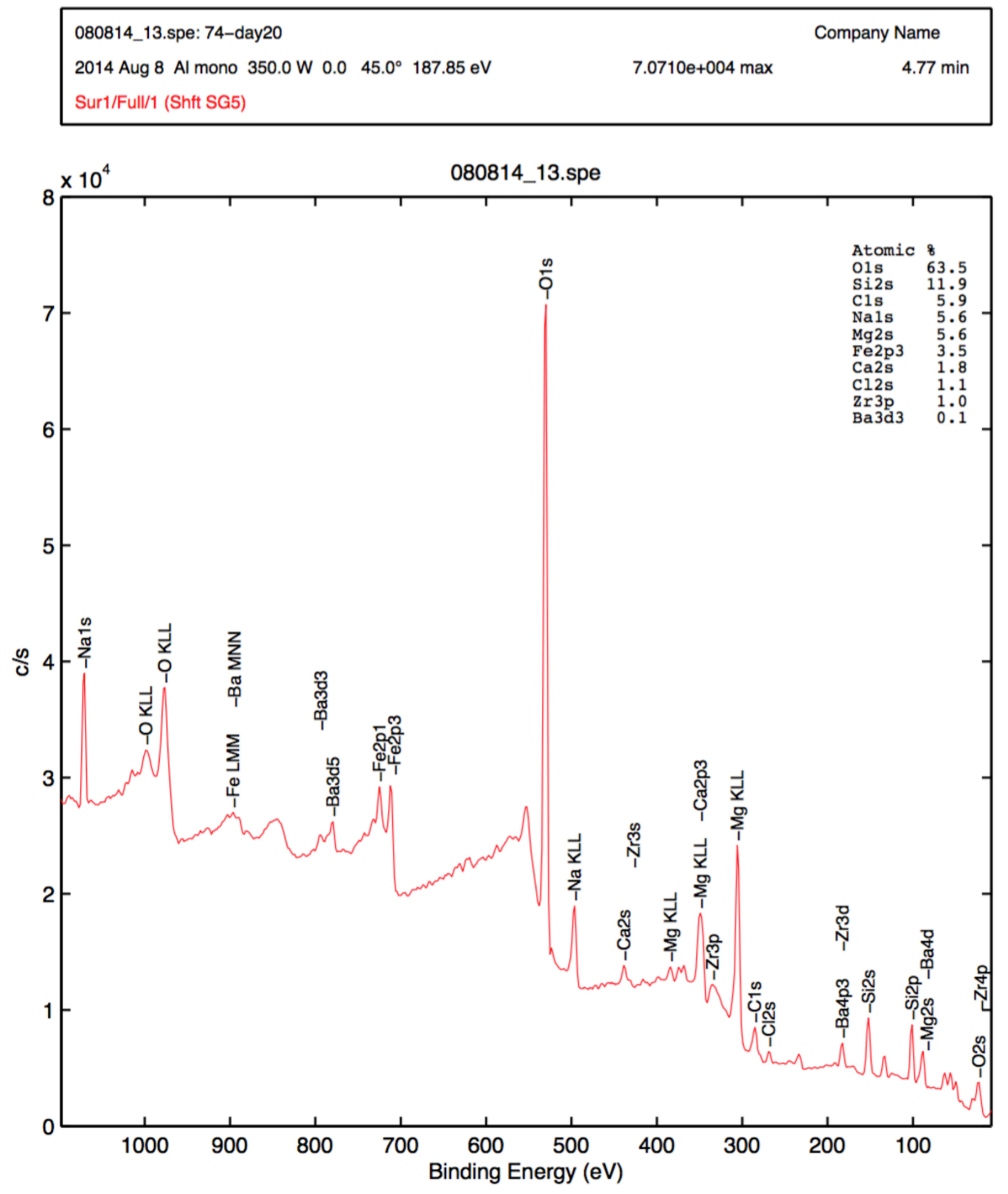

